Rhode Island College

Digital Commons @ RIC

\title{
A Comparison of the Efficacy of Mupirocin Versus Povidone- iodine in the Treatment of Nasal Colonization with MRSA/MSSA to Prevent Pos-operative Infections: An Integrative Review
}

Ashley O'Rourke

Follow this and additional works at: https://digitalcommons.ric.edu/etd

\section{Recommended Citation}

O'Rourke, Ashley, "A Comparison of the Efficacy of Mupirocin Versus Povidone-iodine in the Treatment of Nasal Colonization with MRSA/MSSA to Prevent Pos-operative Infections: An Integrative Review" (2020). Master's Theses, Dissertations, Graduate Research and Major Papers Overview. 362.

https://digitalcommons.ric.edu/etd/362 

A COMPARISON OF THE EFFICACY OF MUPIROCIN VERSUS POVIDONEIODINE IN THE TREATMENT OF NASAL COLONIZATION WITH MRSA/MSSA TO PREVENT POST-OPERATIVE INFECTIONS: AN INTEGRATIVE REVIEW

A Major Paper Presented

by

Ashley O'Rourke

Approved:

Committee Chairperson

Committee Members

(Date)

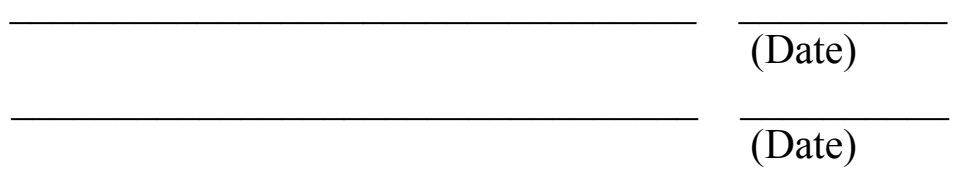

Director of Master's Program

(Date)

Dean, School of Nursing 
A COMPARISON OF THE EFFICACY OF MUPIROCIN VERSUS POVIDONEIODINE IN THE TREATMENT OF NASAL COLONIZATION WITH MRSA/MSSA

TO PREVENT POST-OPERATIVE INFECTIONS: AN INTEGRATIVE REVIEW

by

Ashley O'Rourke

A Major Paper Submitted in Partial Fulfillment

of the Requirements for the Degree of

Master of Science in Nursing

in

The School of Nursing

Rhode Island College

2020 



\begin{abstract}
Surgical site infections are defined by the CDC as infections that occur after surgery in the part of the body that the surgery took place. Surgical site infections are now the costliest and most common hospital acquired infections. It is important for healthcare practitioners to prevent this costly and deadly surgical complication. The use of intranasal mupirocin has been widely used in healthcare institutions but due to concerns regarding cost, mupirocin resistance, compliance rates, and effectiveness, alternatives are being pursued. An important and promising alternative is intranasal povidone-iodine. The purpose of this integrative review was to compare the effectiveness of intranasal mupirocin versus intranasal povidone-iodine to treat nasal colonization with MSSA/MRSA to prevent post-operative surgical site infections. A search was completed including CINAHL, PubMed, and Google Scholar using keywords and inclusion and exclusion criteria, resulting in six studies being included. The selection of research articles was guided by the Preferred Reporting Items for Systematic Reviews and MetaAnalyses (PRISMA) flow diagram. Critical appraisal was conducted utilizing Polit and Beck's Guide to an Overall Critique of Qualitative Research, Quantitative Research Report, and Literature Reviews. Data collection for this review was performed using tables created specifically for this review. A cross-study analysis was conducted and summarized using descriptive data synthesis. Findings included that using intranasal povidone-iodine pre-operatively was as effective as intranasal mupirocin in the decolonization of MSSA/MRSA in the nares in the prevention of post-operative SSIs. More research is needed including further randomized control trials and larger studies, which the nurse practitioner can facilitate, research, educate, and promote to encourage policy change within their institution.
\end{abstract}




\section{Acknowledgements}

I would like to thank my husband, for without you I never would have made it this far. For all the times I wanted to give up, you encouraged me to fulfill my dream and keep going. You put in endless hours taking care of our young children to allow me time for my studies, never once complaining. You have been my rock and my biggest supporter for the past four years and for you, I am eternally grateful.

To Doctor Cynthia Padula, my first reader, I cannot thank you enough for all of your time, patience, and guidance in the completion of this major paper. 


\section{Table of Contents}

Background/Statement of the Problem .......................................................... 1

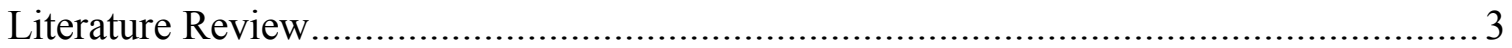

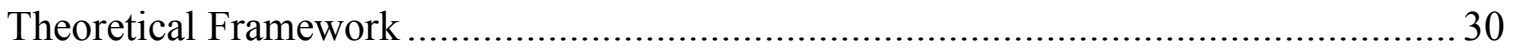

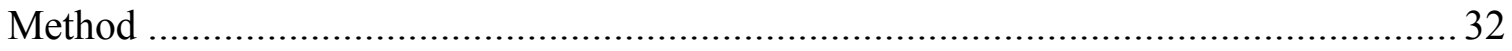

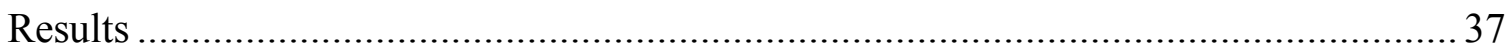

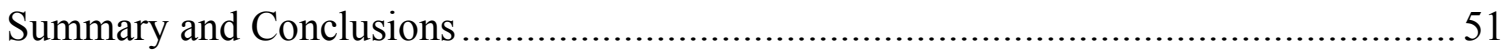

Recommendations and Implications for Advanced Nursing Practice .........................56

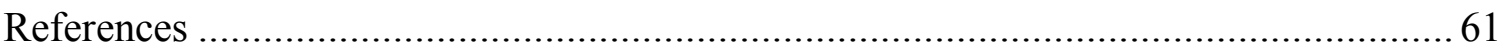

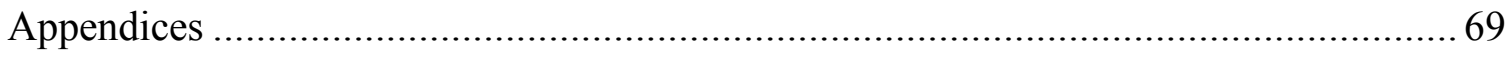


A Comparison of the Efficacy of Mupirocin Versus Povidone-Iodine in the Treatment of Nasal Colonization with MRSA/MSSA to Prevent Post-Operative Infections:

An Integrative Review

\section{Background/Statement of the Problem}

Post-operative infections are an unfortunate complication after surgery that health care providers go to great lengths to prevent. There are many strategies used to prevent post-operative infections such as maintaining a sterile operating room and strict hand hygiene both during and after surgery. Despite the implementation of preventive strategies, post-operative infection remains a problem for a variety of reasons. One specific etiology relates to the fact that some people are colonized in their nostrils with bacteria which, left untreated, can invade the surgical site, causing a post-operative infection.

Two types of bacteria commonly colonized in the nostrils that have the potential to cause a post-operative infection are methicillin resistant staphylococcus aureus (MRSA) and methicillin sensitive staphylococcus aureus (MSSA). As much as 30\% of the population are asymptomatically colonized with staphylococcus aureus (Sakr, Bregeon, Mege, Rolain, \& Blin, 2018). Staphylococcus aureus can be found in various parts of the body including the skin, rectum, vagina, gastrointestinal tract, axilla, and the anterior nares. The anterior nares are the most common site of colonization (Sakr et al.). Nasal colonization with staphylococcus aureus can cause opportunistic and potentially life-threatening infections, such as surgical site infections (SSIs), that increase morbidity, mortality, and healthcare costs (Sakr et al.). 
Patients colonized in the nares with MRSA have a 30\% increased risk of developing a MRSA infection during their hospital stay (Sai, Laurent, Strale, Denis, \& Byl, 2015). Therefore, it has become an important preventive strategy to test patients for a MRSA/MSSA infection before surgery, as decolonization is most effective in these populations that are only at risk for a short period of time (Septimus \& Schweizer, 2016). Many people colonized in the nostrils with MRSA/MSSA are asymptomatic and thus unaware that they are carriers. Between $15-30 \%$ of healthy adults are nasally colonized with MSSA and 1-3\% are colonized with MRSA; these patients have higher bacterial loads and are at an increased risk of developing an infection due to their colonization (Septimus \& Schweizer).

Treatment with five days of mupirocin ointment to both nostrils before surgery to eradicate the MRSA/MSSA living in the nose has been shown to significantly reduce staphylococcus aureus infection. Historically, this treatment has been commonly used but growing mupirocin resistance is developing, and alternatives are being sought (Phillips et al., 2014). Currently, there are studies showing that a swab of povidone-iodine to the nares immediately before surgery is just as effective as the mupirocin ointment and compliance with treatment is improved since it is administered at the hospital before surgery (Phillips et al.). This treatment is being implemented at various hospitals around the country. The purpose of this project was to determine the effectiveness of nasal mupirocin vs. nasal povidone-iodine administered pre-operatively for the decolonization of MRSA/MSSA in the nares to prevent the incidence of post-operative infection.

Next, the literature review will be presented. 


\section{Literature Review}

\section{Post-Operative Surgical Site Infections: Definition and Incidence}

The skin is the largest organ of the body and the first line of defense against infections. If the skin is breached either surgically or by trauma, the body is at risk for infection (Surahio, Talpur, Memon, Junejo, \& Laghari, 2017). Surgical site infection (SSI) remains a substantial cause of morbidity and mortality as well as the cause of prolonged hospitalizations. Surgical site infections are the second most common type of adverse event that occur in hospitalized patients after surgery and are one of the most common surgical complications (Cheng, Li, Kong, Wang, Ye, \& Xia, 2015).

The term 'surgical site infection' was developed by the Centers for Disease Control (CDC) in 1992 (Owens \& Stoessel, 2008). A surgical site infection is defined by the $\mathrm{CDC}$ as an infection that occurs after surgery in the part of the body that the surgery took place (CDC, 2019). The CDC has specific SSI criteria which include: superficial incisional surgical site infection; deep incisional surgical site infection; and organ/space surgical site infection (CDC).

A superficial incisional surgical site infection must meet the following criteria: an infection occurring within 30 days of the operative procedure; involves only the skin and subcutaneous tissue of the incision; and has purulent drainage from the incision site, organism identified by aseptically-obtained specimen, or signs and symptoms of an infection (CDC, 2019). Criteria for a deep incisional surgical site infection include: occurs within 30-90 of the operative procedure; involves deep, soft tissues of the incision; and has purulent drainage from the incision, organisms identified via a culture swab, or at 
least one sign or symptom of infection (CDC). An organ/space surgical site infection must meet the following criteria: infection occurs within 30-90 days of the operative procedure; involves any part of the body deeper than the fascia/muscle layers; has purulent drainage, organisms identified via culture, or abscess or infection identified via exam; and must be an approved organ/space infection site (CDC).

Until the middle of the $19^{\text {th }}$ century, most wounds became infected and those that were extensive resulted in a mortality rate of $70-80 \%$. The rates of surgical site infections drastically improved when Ignaz Semmelweis and Joseph Lister pioneered infection control by introducing anti-septic surgery. Despite these advances, the overall incidence of healthcare associated infections (HAIs) remains high (Bandaru, Rao, Prasad, \& Murty, 2012). Surgical site infections are now the costliest and most common hospital acquired infections (Anderson et al., 2014).

Surgical site infection rates are estimated at less than $1 \%$ to more than $10 \%$, with $75 \%$ of SSI-associated deaths directly attributed to a SSI (Cheng et al., 2015). This poses a large economic and financial burden on the patient, their family, and the healthcare institution. The incidence of SSI differs greatly depending on the hospital and from one geographic location to another. While a SSI is a serious threat to patients' lives, it is also a large financial burden on patients, families, and society (Cheng et al.). Patients with SSIs are more likely to require hospital readmission, possibly to an intensive care unit and are at higher risk of death than those without infections (Owens \& Stoessel, 2008).

The financial burden of an SSI is approximately twice the amount of in-patient costs for those without a SSI. A study of hospital-acquired infections in Massachusetts 
estimated the cost to be between $\$ 223,000,000$ and $\$ 275,000,000$ (Stone, Kunches, \& Hirschhorn, 2009). Surgical site infections are estimated to account for 3.5 to 10 billion dollars annually in health care expenditures (Anderson et. al, 2014). Surgical site infections are associated with a mortality rate of $3 \%$ with $75 \%$ of SSI-associated deaths being directly attributed to an SSI (CDC, 2019). Therefore, is imperative that SSIs are identified and diagnosed early and are treated immediately upon diagnosis. Factors responsible for surgical site infections must be identified and measures must be taken to prevent these factors from occurring to reduce morbidity, mortality, and healthcare expenses (Cheng et al., 2015).

\section{Risk and Contributing Factors for Surgical Site Infections}

There are two different categories of factors that place a person at increased risk for a SSI. These categories are patient-related (endogenous) or procedure-related (exogenous) factors (Owens \& Stoessel, 2008). Patient-related factors include advanced age, nutritional status, diabetes, smoking, obesity, coexistent infection at a remote body site, colonization with micro-organisms, altered immune response, and length of preoperative hospital stay. Procedure-related factors include duration of surgical scrub, skin antisepsis, preoperative shaving, preoperative skin preparation, duration of operation, antimicrobial prophylaxis, operating room ventilation, inadequate sterilization of surgical instruments, foreign material in the surgical site, surgical drains, and surgical technique (Owens \& Stoessel). Further procedure-related factors include: contamination from members of the surgical team; the operating room environment; and instruments brought into the sterile field used during the surgical procedure. The organisms 
associated with exogenous factors include staphylococci and streptococci (Owens \& Stoessel).

A study by Alfonso-Sanchez, Martinez, Martin-Moreno, Gonzalez, and Botia (2017) examined the risk factors influencing surgical site infections. This was a longitudinal prospective study at eight different hospitals designed to identify SSIs in all patients who underwent surgical procedures. The patient-related variables included in this study were: age; sex; number of comorbidities; diabetes; cancer; chronic obstructive pulmonary disease; hepatic cirrhosis; smoking; immunosuppression; nutrition; nasogastric tube feeding; transfusion; and length of preoperative stay. The variables associated with the operation included: antibiotic prophylaxis; depilation; American Society of Anesthesiologists (ASA) class; type of intervention; and duration of intervention.

The sample size included 18, 910 patients, with 1,267 (6.7\%) developing a SSI. The most significant environmental factor risk was contamination in the operating room by bacteria and fungi. Bacteria caused $1.75 \%$ of infections $(\mathrm{p}=<0.001)$ and fungi with greater than 6 CFU caused $6.23 \%$ of infections $(p=<0.001)$. Each type of surgical infection was found to have different associated risk factors. Superficial SSIs were associated with environmental factors such as contamination by fungi and bacteria, surface contamination, humidity, differential pressure, and temperature of the operating room. Whereas the factors associated with deep organ/space SSIs were associated with patient characteristics such as age, sex, transfusion, nasogastric feeding, nutrition, type of intervention, and preoperative stay. 
In addition to the above stated risk factors, the virulence of the bacteria and the procedure performed are also important determinants in the development of a wound infection (Surahio et al., 2017). Most wounds infections only involve the skin and subcutaneous tissue but if left untreated or not adequately treated early and aggressively, they can lead to a more serious infection or sepsis (Surahio et al.). Presenting signs of an infection usually involve increasing pain at the wound, fever, and/or discharge from the wound. They may also present with erythema and tenderness to the incision site (Surahio et al.).

\section{Pathogens and Surgical Site Infection}

While there are endogenous and exogenous related factors for developing a SSI, the most responsible pathogens originate from the patient's endogenous flora. There are many organisms related to SSIs but the most common are staphylococcus aureus, coagulase-negative staphylococci, Enterococcus spp., and Escherichia coli with an increasing number related to antibiotic-resistant organisms such as methicillin resistant staphylococcus aureus (MRSA) (Owens \& Stoessel, 2008). Patients infected with MRSA have an $18 \%$ mortality rate, even among healthy patients (Loftus, Dexter, \& Robinson, 2018). Recent evidence concluded that the MRSA infection rate in 2015 was no different than the 2010-2011 baseline (Kavanagh, Abusalem, \& Calderon, 2017).

Cheng et al. (2015) conducted a prospective study at a tertiary care center from July 2013 to December 2014 which included 1,138 patients aged two to 92 who underwent breast, hernia, esophagus, stomach, appendix, colon, or rectal surgery. The purpose of the study was to identify risk factors for surgical site infections in a teaching 
hospital. The authors found a significant association between the age of the patient and the development of a surgical site infection. Patients aged over 75 years were more likely to develop a surgical site infection $(5.6 \% ; \mathrm{n}=161)$ than those less than 75 years of age $(3.0 \% ; n=977)$. They also found that there was a correlation between those patients with diabetes (odds ratio $[\mathrm{OR}] 6.400 ; 95 \%$ confidence interval $[\mathrm{CI}] 2.582-15.866 ; p=0.000$ ); and/or cancer (OR 2.427; 95\% CI 1.028-5.732; $p=0.043$ ); and being at an increased likelihood for developing a SSI. Patients with diabetes are more susceptible to a wound infection because of impaired neutrophil chemotaxis and phagocytosis. There was a significant difference between the diabetic and non-diabetic groups; the percentage of surgical site infections in diabetic patients was higher $(14.3 \% ; \mathrm{n}=77)(\mathrm{p}=30.660)$ than for non-diabetics $(2.5 \% ; \mathrm{n}=1,061)(\mathrm{p}=0.000)$. Patients with cancer are at increased risk for a SSI due to immunosuppression and their reduced ability to fight of infection. The percentage of patients with an SSI who had cancer was $8.4 \%(n=77, p=10.559)$ and those without cancer was $2.7 \%(\mathrm{n}=1,019, \mathrm{p}=0.001)$. There was a higher incidence of surgical site infection in emergency surgery cases $(8.4 \% ; \mathrm{n}=166)$ than elective surgery cases $(2.5 \% ; \mathrm{n}=972)$ because emergency procedures do not allow for stable vital signs, adequate antiseptic skin preparation, and decontamination of the colon prior to colon surgery. P-value for elective surgery was $\mathrm{p}=.000$ (Cheng et al.).

This study isolated 20 different organisms as causing the surgical site infections, with the most prominent being Escherichia coli, S. aureus, and Pseudomonas aeruginosa. Based on this, it was recommended that preventive measures should be strengthened to reduce the incidence of SSI. Furthermore, this study showed that there was an increase in surgical site infection with the increasing volume of blood transfusions. The incidence of 
surgical site infection was higher $(10.7 \% ; n=56)$ in those who received transfusions than in those who did not $(3.0 \% ; n=1,082)$ with a P-value of 0.002 . The authors concluded that patients should not receive blood transfusions unless absolutely necessary (Cheng et al., 2015).

Surahio et al. (2017) performed a prospective, descriptive study to determine the frequency of SSIs in postoperative patients and to evaluate the type of organism involved in post-operative infections and its sensitivity. All patients were older than 13 years and underwent surgery and subsequently developed a surgical wound infection. The study was performed over a one-year period and included 424 patients. The results indicated that $2.25 \%(n=8)$ of patients developed a grade I infection, $11.58 \%(n=41)$ developed a grade II infection, $1.41 \%(\mathrm{n}=5)$ developed a grade III infection, and $0.28 \%(\mathrm{n}=1)$ developed at grade IV infection. Twenty-three of these patients underwent an appendectomy, five had inguinal hernia surgery, nine patients had a laparotomy, and eight patients underwent a cholecystectomy (Surahio et al.).

The most common organisms isolated from the infected post-operative wounds were Escherichia coli, which infected 24 patients and S. aureus which infected six patients. When an antibiotic sensitivity was performed it showed that meropenem and piperacillin/tazobactam were effective against these organisms. Meropenem was sensitive in $96.15 \%(n=25)$ of patients with Escherichia coli and $87.5 \%(n=7)$ with S. aureus. Piperacillin/tazobactam was sensitive in $92.30 \%(n=24)$ of patients with Escherichia coli and $75 \%(n=6)$ with S. aureus. Vancomycin was found to be sensitive to S. aureus in $87.5 \%(n=7)$ of patients and $100 \%(n=3)$ of patients with streptococci (Surahio et al., 2017). 
The authors concluded that wound infection caused significant morbidity in $15.53 \%$ of surgical cases and had a significant economic burden on patients and hospitals. The authors noted that antibiotics should only be used after sensitivity reports have been reviewed to avoid the development and persistence of antibiotic resistant organisms. Of most importance is maintaining optimal conditions as much as possible to avoid post-operative infections and the need to use antibiotics (Surahio et al., 2017).

\section{Prevention of Post-Operative Surgical Site Infections: The Surgical Care Improvement Project (SCIP)}

As a result of the high cost of SSIs and the increased mortality rates associated with inconsistent compliance with infection prevention measures, the Surgical Infection Prevention (SIP) project was created by the Centers for Medicare \& Medicaid Services (CMS) and the CDC. The SIP was created after The Joint Commission (TJC) created four core measurement areas for hospitals: acute myocardial infarction; heart failure; pneumonia; and pregnancy related conditions in 2001 (National Hospital Inpatient Quality Measures Specifications Manual [NHIQMSM], 2014). The SIP focused on seven procedures: abdominal hysterectomy; vaginal hysterectomy; hip arthroplasty; knee arthroplasty; cardiac surgery; vascular surgery; and colorectal surgery (Anderson et al., 2014). After TJC began collecting data on the four core measurement areas, they subsequently created the Surgical Care Improvement Project (SCIP) in 2006 which included seven SCIP performance and outcome measures applicable to the peri-operative period. These measures include: prophylactic antibiotic received within 1 hour prior to surgical incision; prophylactic antibiotic selection for surgical patients; prophylactic antibiotics discontinued within 24 hours after surgery; controlled postoperative blood 
glucose; appropriate hair removal; urinary catheter removed on post-operative day 1 or 2 ; and peri-operative temperature management (NHIQMSM).

The first SCIP outcome pertains to the timing of the first administration of prophylactic antibiotics as well as the timely discontinuation of prophylactic antibiotics (NHIQMSM, 2014). The goal of prophylactic antibiotics is to establish bactericidal tissue and serum levels at the time of the skin incision (NHIQMSM). Studies have demonstrated that the administration of systemic antibiotics prophylactically before surgery decreases the incidence of wound infections by about one half. While there are great benefits to using antibiotics prophylactically, it is also important to discontinue them in a timely manner to prevent adverse effects such as the development of antibiotic resistant pathogens or Clostridium difficile infections (Rosenberger et al., 2011).

For the above reasons, strict guidelines have been created concerning the administration of prophylactic antibiotics prior to surgery. Primarily, the timing of the administration of the antibiotics is important (Alexander et al., 2011). It is recommended that the antibiotics are administered within the first two hours before surgery, depending on the half-life of the medication. For antibiotics with a short half-life, such as the cephalosporins, they should be administered 30 minutes before the incision to ensure the most effectiveness. Longer acting antibiotics such as vancomycin and the fluoroquinolones should be administered one to two hours before the incision is made. Re-dosing is necessary in the use of short acting antibiotics and should be administered every three hours after the incision is made with the dosage adjusted for large body size (Alexander et al.). 
The second SCIP outcome pertains to the choice of antibiotics which is made based on the half-life of the medication and the length of the surgery as well as the surgery being considered clean or dirty (Rosenberger et al., 2011). The goal of antibiotic prophylaxis is to be cost effective, safe, and a broad spectrum covering the most probable intraoperative contaminants encountered during surgery (NHIQMSM, 2014). The cephalosporins provide good early penetration into the wounds and are effective against gram-positive and gram-negative organisms commonly encountered in general surgery (Rosenberger et al., 2011). Cefazolin is the drug of choice for most surgeries, with vancomycin being the second choice but not preferred due to its' potential for antibiotic resistance (NHIQMSM). The longer acting antibiotics such as vancomycin and fluoroquinolones provide lasting penetration for longer surgical cases (Alexander et al., 2011). Cefazolin is the drug of choice for most surgeries including: burns; general surgery; genitourinary; hepatobiliary; oral/maxillofacial; orthopedic spine surgery; obstetrics; gynecology; and plastic surgery. Cefazolin plus vancomycin is recommended for cardiac surgery, neurosurgery, orthopedic, and vascular surgery (Alexander et al.).

The third SCIP outcome recommends the discontinuation of prophylactic antibiotics within 24 hours; no benefit had been noted beyond 24 hours post-operatively. Peri-operative antibiotics do not sterilize tissues but reduce the bacterial burden to an amount that may be controlled by the patient's own defenses (Alexander et al., 2011). The continuation of antibiotics beyond 24 hours leads to a risk of drug resistance and secondary infections such as Clostridium difficile and has not shown any benefit in SSI reduction beyond a single dose of antibiotics (Rosenberger et al., 2011). 
Surgical Care Improvement Project outcome number four concerns euglycemia in the prevention of SSIs, most notably for cardiac surgery patients (NHIQMSM, 2014). Of most importance are post-operative days one and two, during which maintaining appropriate glucose concentrations reduces the incidence of SSIs (Rosenberger et al., 2011). It has been well documented that patients with diabetes who undergo surgery have an increased incidence of complications which include poor wound healing, wound infections, cardiac compromise, and death (Alexander et al., 2011). The adverse effects of poor glucose control are vast and include: disturbances of microvascular responses; inhibition of complement function; increases in pro-inflammatory cytokine levels; inhibition of chemotaxins; impaired phagocytosis and intracellular killing; disturbances in reactive oxygen species; decrease in T and B cell responses; and increased apoptosis and oxidative stress in the lymphocytes. It is recommended to closely monitor the blood glucose to less than $180 \mathrm{mg} / \mathrm{dL}$ for $18-24$ hours after anesthesia end time (NHIQMSM).

Surgical Care Improvement Project outcome number six relates to the method of hair removal. The accepted methods of hair removal include no hair removal or using clippers or depilatory (NHIQMSM, 2014). In a prospective study by Ko, Lazenby, Zelano, and Isom (1992) the effects of hair removal methods were investigated on suppurative mediastinitis after cardiopulmonary bypass operations on 1,980 consecutive adult patients over a two-year period. Each group was randomized to manual shaving versus electrical clipping of hair before the surgical incision. The infection rate was significantly higher in the manually shaven group (13/990) versus the electrically clipped group (4/990). It is recommended to electrically clip hair to avoid skin damage associated with shaving hair with a razor (Alexander et al., 2011). 
The extensively studied topic of prevention of catheter associated urinary tract infections (CAUTI) are the focus of outcome nine from SCIP. It is recommended that the urinary catheter is removed on postoperative day one or postoperative day two (NHIQMSM, 2014). Studies have found that the likelihood of developing a CAUTI directly correlates with the duration of catheter use (Rosenberger et al., 2011). Patients with catheters in place for longer than two days post-operatively have been found to have twice the chance of developing a urinary tract infection (UTI) than those who have a catheter for less than two days (Rosenberger et al.).

The final outcome, SCIP number 10, pertains to the maintenance of normothermia peri-operatively to reduce SSIs. Normothermia during surgery, according to SCIP, is defined as at least one body temperature equal to or greater than 96.8 degrees Fahrenheit recorded within 15 minutes before the surgery end time (NHIQMSM, 2014). Studies have indicated that maintaining normothermia during surgery was associated with lower rates of SSIs. It is hypothesized that hypothermia leads to peripheral vasoconstriction and impaired immune function which leads to higher rates of SSIs (Rosenberger et al., 2011). Hypothermia also contributes to: increased blood loss and transfusion requirements; prolonged anesthesia recovery; prolonged hospitalization; increased morbid myocardial events; and increased wound infections (Alexander et al., 2011). It has been shown in animal studies that an increase in the core temperature that occurs during bacterial infections is essential for optimal antimicrobial host defense (Alexander et al.).

A study by Yi, Liang, Song, Xia, and Huang (2018) was conducted to evaluate if active warming practices during surgery reduced bleeding in patients undergoing major open operations. This was a prospective, parallel two-arm randomized controlled trial 
that compared active warming and passive warming practices amongst unilateral total hip replacement surgeries and open thoracic operations. The passive warming group included those covered with un-warmed cotton blankets from pre-operative holding area to operating room to post-anesthesia care unit. The active warming group members were covered with forced-air blankets connected to a warming unit during the pre-operative holding area and in the operating room. The incidence of hypothermia ( $<36$ degrees Celsius) during surgery was $0 \%$ in the active warming group whereas the incidence was $71.8 \%$ in the passive warming group. Most importantly, the study found that the combined volume of intraoperative blood loss for the two operations was significantly less in the active warming group (464ml) than the passive warming group $(682 \mathrm{ml})$. Therefore, it was concluded that it would be beneficial to implement active warming protocols to reduce SSIs (Yi et al.)

\section{Other Surgical Site Infection Prevention Guidelines}

Further recommendations for prevention of SSIs in addition to the SCIP outcomes have been identified by the CDC. The CDC guidelines for prevention of SSIs were created in 1999 and updated in 2017. The most current CDC guidelines for the prevention of SSIs include: showering or bathing with an antiseptic agent at least the night before surgery; antimicrobial prophylaxis administered when indicated and timed appropriately; skin preparation in the operating room with an alcohol based agent; no additional prophylactic antimicrobials administered after the surgical incision is closed; maintaining blood glucose less than 200mg/dL; maintaining normothermia; oxygen administration during surgery; and refraining from the transfusion of blood products (Berrios-Torres, Umscheid, \& Bratzler, 2017). Other SSI prevention guidelines include techniques for air 
handling, cleaning of environmental surfaces, sterilization techniques, activities of surgical team members, surgical attire, drapes, and asepsis (Alexander et al., 2011). In regard to air handling, microbes in the air are a major source of pathogens for causing wound infections and high efficiency filters provide the best way to filter the air. Another big source of contamination in the operating room is glove perforation which significantly increases the risk of infection. Double gloving has been shown to greatly decrease glove perforation (Alexander et al.).

Post-operative infections are frequently caused by organisms that are already on the skin, most commonly S. aureus. In the years before 1970, studies showed that bathing with hexachlorophene before surgery reduced the risk of wound infections. This practice was later switched to chlorhexidine baths because they provide better long-term suppression of organisms; this is now the agent of choice (Alexander et al., 2011). According to the CDC guidelines from 2014, patients are advised to shower or bathe with soap or an antiseptic agent at least the night before the operative day. This is classified as a category IB strong recommendation (Berrios-Torres et al., 2017). Showering with chlorhexidine pre-operatively has been shown to be more effective in reducing the number of organisms on the skin than iodine or soap and water. People who are nasal carriers of S. aureus or MRSA are likely to have other body sites that are also contaminated with the same organisms. Thus, they are at risk for endogenous transmission of S. aureus infections (Alexander et al.).

Preventing post-operative infections does not depend on just one variable. It is a complex process and it varies based on the patient, the surgical environment, and the surgical technique. Measures need to be taken to address each of these areas. Important 
guidelines to follow in the prevention of post-operative infections are: correct timing of prophylactic antibiotics; intraoperative normothermia; avoiding urinary tract catheterization; adhering to basic hand hygiene; and more recently to decolonize the skin and nares with chlorhexidine (Andersson, Bergh, Karlsson, Eriksson, \& Nilsson, 2012).

\section{Staphylococcus Aureus and Surgical Site Infections}

Staphylococcus aureus. Staphylococcus aureus is a gram-positive bacteria that can cause a variety of infections ranging from skin and soft tissue infections to lifethreatening blood infections and sepsis (Hogan et al., 2016). It is a human skin and mucosa commensal and is a frequent cause of serious infections with a high morbidity and mortality as well as increased healthcare-associated costs (Sakr et al., 2018). Staphylococcus aureus is identified as a bacteria that commonly causes opportunistic infections from skin infections to toxic shock syndrome, endocarditis, pneumonia, and sepsis. Due to this, it is now recognized as a common cause of hospital- acquired and community- acquired infections (Waryah et al., 2016). Staphylococcus aureus is dispersed from a provider's hands and patient skin surfaces and is then capable of contaminating aerosolized particles, equipment, and tools such as laryngoscope blades, laryngoscope handles, anesthesia machines, and ventilators. It has been shown to survive on surfaces for up to 360 days (Loftus, Dexter, \& Robinson, 2018).

Staphylococcus aureus develops due to several virulence factors which include biofilm formation, antibiotic resistance, and the production of a wide array of toxins (Waryah et al., 2016). Primarily, a biofilm, which is a congregation of microorganisms residing in a protective extracellular matrix, forms around the bacteria (Waryah et al.). 
This is followed by the second stage, which involves colonization of the bacteria by means of adherence factors or adhesions which aid in attachment of the bacteria to the host surface. This is done by a microbial surface component which recognizes adhesive matrix molecules. There are over 20 different adhesive matrix molecules that can express S. aureus (Waryah et al.).

Once the bacteria adhere to the host surface, the biofilm is strengthened further by an intracellular adhesion encoded by a cell surface polysaccharide and an antigen. Furthermore, S. aureus produces a variety of endotoxins which contribute to host tissue membrane disruption and provide nutrients that are essential to bacterial cell growth (Waryah et al., 2016). Given these factors, combined with the over use of antibiotics, development of persistent antibiotic resistance has improved the ability of S. aureus to resist treatment with antibiotics (Waryah et al.).

Bacteria that produce biofilms contribute to greater than $80 \%$ of all infections in humans (Piechota et al., 2018). These bacteria are a primary cause of healthcareassociated infections because the biofilm show increased resistance against standard antimicrobial treatment and host immune factors and is able to colonize medical surfaces such as catheters and other devices (Piechota et al.). A study by Piechota et al. (2018) aimed to investigate the capacity of clinical strains of S. aureus to form biofilms. They collected S. aureus strains from two hospitals between 2015 and 2017 and divided them into two groups: MSSA strains and MRSA strains. There were 57 strains of MSSA and 73 strains of MRSA. All strains were evaluated for biofilm production and out of 130 strains, $99.2 \%$ were biofilm producers. Due to the high incidence of biofilm formation by both MSSA and MRSA, there is a high ability of these strains to persist in hospital 
environments and increase the risk of drug resistant infections in hospitalized patients (Piechota et al.).

Staphylococcus aureus is one of the most common causes of bacteremia and currently carries a $20-40 \%$ mortality rate after an infection of up to 30 days despite medical treatment (Piechota et al., 2018). Staphylococcus aureus can cause opportunistic disease in the hospital as well as the community setting (Kim et al., 2018). Over the last 20 years, infections caused by S. aureus have become more dangerous and costly to treat due to the increasing prevalence of antibiotic resistance due to the widespread use of antibiotics (Piechota et al.). Staphylococcus aureus initially responded well to the betalactam group of antibiotics, but with the evolution of MRSA being reported in such a short period of time, it is now resistant to most antibiotics except for vancomycin (Hussain, Naqvi, \& Sharaz, 2019). Methicillin resistance is mediated by a penicillinbinding protein encoded by a gene that allows the organism to grow and divide in the presence of methicillin and other beta-lactam antibiotics (Sfeir et al., 2014). The primary drug resistant strains of S. aureus are methicillin-sensitive staphylococcus aureus (MSSA) and methicillin-resistant staphylococcus aureus (MRSA). Methicillin sensitive staphylococcus aureus causes approximately half of all healthcare associated S. aureus infections (Kourtis et al., 2019).

Methicillin Resistant Staphylococcus Aureus. Methicillin resistant staphylococcus aureus infections first began being reported in 1950 and infection rates have increased dramatically in recent decades, reaching up to $50 \%$, with $30 \%$ of patients infected with MRSA dying within 30 days (Al-Tamimi et al., 2018). Hospitals are the main source of MRSA outbreaks; this is due to a variety of factors including prolonged 
hospital stay, widespread use of antibiotics, nursing home exposure, immune suppression, improper antibiotic dosage, indwelling catheterization, invasive medical devices, drug abusers, and unsterilized instrumentations (Hussain et al., 2019). The prevalence of MRSA has increased in the United States over the past 10 years from $32.7 \%$ in 1998 to $53.8 \%$ in 2007, with MRSA related hospitalizations doubled (Hussain et al.). Methicillin resistant staphylococcus aureus is associated with severe and prolonged infections, with invasive MRSA infections reported to have an $18 \%$ mortality rate among healthy patients in the community (Loftus et al., 2018). Methicillin resistant staphylococcus aureus has been shown to be more likely than MSSA to be implicated in intraoperative clonal transmission (Loftus et al.).

In a study by Hussain et al. (2019), the authors aimed to identify the prevalence of MRSA in a tertiary care hospital. They performed a cross sectional study over a sixmonth period during which 100 clinical specimens of pus and wounds were collected. The findings showed that out of the 100 clinical specimens, 65 of them showed bacterial growth. Of these 65 samples, 27 were gram positive cocci, and 38 were gram negative rods. Of the 27 gram positive cocci, 21 were S. aureus. Of the $21 \mathrm{~S}$. aureus samples, 14 were MRSA and seven were MSSA. It is important to identify this nosocomial pathogen early to prevent its' dissemination and life-threatening complications.

While the MRSA rate is higher in hospitalized patients, there is growing frequency of community acquired MRSA (Al-Tamimi et al., 2018). Community acquired MRSA infections were first identified in the 1990s, which caused mostly soft tissue infections (Kourtis et al., 2019). It was first reported among injection drug users and is now the most frequent cause of skin and soft tissue infections (Sfeir et al., 2014). 
Community acquired MRSA can also cause bacteremia, infective endocarditis, pneumonia, bone and joint infections, (Kim et al., 2018) necrotizing fasciitis, wound infections, otitis media, otitis externa, osteomyelitis, urinary tract infections, sepsis, and necrotizing pneumonia (Sfeir et al.).

Community outbreaks have been reported in native and aboriginal communities, sports teams, child-care centers, military personnel, men who have sex with men, and prison inmates and guards (Sfeir et al., 2014). Risk factors for development of a community MRSA infection include: skin trauma; cosmetic body shaving; incarceration; sharing of unclean equipment between users; and physical contact with others who have MRSA colonization or a MRSA infection (Sfeir et al.). Community acquired MRSA is now seen with increasing frequency in the hospital setting due to patients who acquire MRSA in the community becoming hospitalized and subsequently transmitting the community strains to other hospitalized patients (Sfeir et al.).

Staphylococcus aureus is a common bacteria in both the hospital and community setting, posing serious risks to the population. With the evolution of S. aureus into the resistant strains of MRSA and MSSA, it is necessary to be even more vigilant to identify and treat these infections early and prevent the transmission of disease. Since S. aureus can colonize a person's skin and mucus membranes, nasal colonization with S. aureus has been at the forefront of recent research in the prevention of post-operative infections.

\section{Nasal colonization with Staphylococcal Aureus}

In the United States, more than 40 million people undergo surgery each year, with more than 20 percent of them acquiring a nosocomial infection during the post-operative 
period. Post-operative infections at the surgical site are the third most common nosocomial infection and complicate $1-10 \%$ of operations. Staphylococcus aureus is the cause of $25 \%$ of nosocomial infections. It colonizes the anterior nares in $25-30 \%$ of the population and those who are colonized with S. aureus are at higher risk for staphylococcal infections after invasive medical or surgical procedures than those who are not colonized (Perl et al., 2002). Nasal colonization is a preoperative risk factor for MRSA and MSSA infections as it can spread from the anterior nares to other areas of the skin and contaminate the incision during surgery (Sakr et al., 2018). Studies have shown that around $80 \%$ of strains that have caused a staphylococcal infection at the surgical site have the same molecular identity as the S. aureus strain in the nares of the infected patient (Saker et al.).

Colonization of S. aureus in the nares has been shown to play a role in the pathogenesis of S. aureus infections in patients undergoing surgery, dialysis, and intensive care unit patients (Sakr et al. 2018). Staphylococcus aureus establishes solid interactions with nasal epithelial cells via various proteins and many cell surface components. The anterior nares are lined by a stratified, keratinized nonciliated squamous epithelium, where the rest of the nasal cavity is lined with a ciliated columnar epithelium. The outermost layer of the anterior nares is the stratum corneum, which contains keratinocytes that express proteins. These proteins are able to interact with staphylococcal surface proteins which favor nasal colonization (Sakr et al.). Colonization depends on the host's defenses due to underlying conditions or diseases. Healthy hosts have lower rates of colonization whereas those with conditions such as human 
immunodeficiency virus (HIV), obesity, diabetes, and dialysis patients have been found to have higher rates of nasal colonization (Sakr et al.).

Staphylococcus aureus can be found in various sites on the body including the skin, rectum, vagina, gastrointestinal tract, and axilla, with the main reservoir being the anterior nares (Sakr et al., 2018). When in contact with the nasal mucosa, S. aureus then interacts with epithelial cell ligands. Once the bacteria overcome the host's defenses, it can propagate into the anterior nares and the host becomes a S. aureus nasal carrier. Nasal carriage can begin within the first days of life, with $90 \%$ of S. aureus strains found to be identical to the maternal nasal strain (Sakr et al.). After birth, the hands are the main source of infection, with transmission occurring from surfaces to the hands and then the nose.

In a study by Loftus et al. (2018), the researchers aimed to identify the source of transmission for S. aureus in the operating room of 274 case pairs of three academic medical centers in the United States. This study involved the first and second cases of the day. Before the first case of the day, samples were taken from the bacterial reservoirs. Bacterial reservoirs for this study included: the anesthesia providers' hands before, during, and after patient care; the adjustable pressure-limiting valve and agent dial of the anesthesia machine; the patients' nasopharynx and axilla; other providers' hands present in the operating room; and the internal lumen of the patients' intravenous stopcock set. These reservoir sites were then sampled after completion of the surgery as well. Before the first case of the day, each environmental site was decontaminated but the sites were not additionally decontaminated before the second case except for usual routine cleaning procedures to assess for the efficacy of routine cleaning procedures. The results of the 
study showed that there were $22 \mathrm{~S}$. aureus strains isolated from intraoperative reservoirs.

Of the $173 \mathrm{~S}$. aureus isolates that were collected, the source of the infection was linked to either the patient, the residents' hand, or unknown. The conclusion of this study indicated that preoperative patient decolonization and perioperative hand hygiene infection control measures need to be improved upon.

Airborne transmission is another possible route, as the risk of disseminating S. aureus during a viral upper respiratory infection increases the risk of infection outbreaks (Sakr et al., 2018). Air transmission is of particular concern in the operating room where it is considered a continuous medium that is able to spread infection to various sites due to the setline of aerosolized particles (Loftus et al., 2018). Healthcare workers who are asymptomatic carriers of S. aureus can also be the source of MRSA outbreaks as well as mobile phones contaminated with S. aureus (Sakr et al.).

Healthcare workers who are asymptomatic carriers of S. aureus are responsible for some of the transmission of S. aureus infections in hospitals. This was studied by AlTamimi et al. (2018) amongst medical students. The authors performed a cross-sectional study which included 290 medical students from the first to fourth year at a medical university. Nasal swabs were collected from each participant under sterile conditions. Out of the 290 nasal swabs, 66 of them (22.7\%) were identified as being infected with S. aureus. Out of these 66 swabs, 54 of them (18.6\%) were identified as MSSA and 12 (4.1\%) were identified as MRSA. Potential risk factors for nasal colonization found in this study included the male sex and chronic illnesses. The study concluded that nasal colonization with S. aureus plays an essential role in transmission of infections and those 
colonized in their nares with MRSA possess a higher risk for transmission of nosocomial infections.

Another study that evaluated the prevalence of MSSA and MRSA among healthcare workers was performed by Hogan et al. (2016). These researchers performed a cross sectional study where they screened nasal swabs from 863 healthcare workers and 685 students for S. aureus. Of these 1548 samples, 171 were isolated as having S. aureus. The prevalence of S. aureus colonization in the healthcare worker group was $10.4 \%$ and $11.4 \%$ in the student group. Methicillin resistant staphylococcus aureus colonization was higher in the healthcare group (1.5\% versus $0.9 \%)$. Nasal colonization was higher among women than men and those greater than the age of 25. Colonization of S. aureus was slightly higher in healthcare workers that reported direct contact with patients.

\section{Treatment of Nasal Colonization with Mupirocin}

Staphylococcus aureus is able to establish colonization in the nasal mucosa, which begins the pathogenesis of disease. Approximately $20 \%$ of people are persistently colonized with S. aureus and $60 \%$ are intermittently colonized in their nares. When patients are hospitalized or develop immune compromise and are colonized with S. aureus in their nares, they are at increased risk of developing a bloodstream infection (Uciyama et al., 2019). Therefore, at-risk patients are screened for MRSA colonization and are decolonized, especially before surgery. Mupirocin has typically been used in the past but due to increased resistance to the drug (approaching 30\% in some clinical populations) and repeated applications required, other alternatives are being sought (Uchiyama et al.). 
The most common treatment for eradication of $\mathrm{S}$. aureus in the nares is with the topical treatment of $2 \%$ mupirocin calcium ointment (bactroban) which decolonizes the anterior nares and aids in preventing post-operative infections; this has been supported by several studies which have reported lower rates of surgical site infections after treatment pre-operatively with mupirocin (Perl et al., 2002). Perl et al. (2002) conducted a clinical trial to determine whether the application of intranasal mupirocin ointment preoperatively would decrease the rate of S. aureus infections at surgical sites. The study was a randomized, double-blind, placebo-controlled clinical trial at two hospitals in Iowa over a period of three years. The study subjects were treated with mupirocin ointment or placebo to the anterior nares twice daily for up to five days before surgery and monitored for 30 days postop to determine whether they acquired S. aureus.

The results of the study showed that the rate of infection at the surgical site was $7.9 \%(n=1,933)$ in the mupirocin group and $8.5 \%(n=1,931)$ in the placebo group. The study also found that the risk of nosocomial infection with S. aureus at any site among patients with nasal colonization of S. aureus was significantly lower among those who received mupirocin $(12.8 \%$; $n=444)$ than those who received the placebo $(16.1 \%$; $n=$ 447) $(\mathrm{p}=0.02)$. Of the participants $(\mathrm{n}=129)$ with nosocomial infections who had nasal carriage of S. aureus, wound cultures were obtained from 107 (43 in the mupirocin group and 64 in the placebo group). Of those who were S. aureus carriers, 17 carriers who received mupirocin developed nosocomial S. aureus infections whereas 34 carriers developed a nosocomial infection in the placebo group. Among those who received the placebo and were S. aureus carriers, there was a 4.5 times higher chance of developing a SSI than non-carriers (Perl et al., 2002). 
While mupirocin has been commonly used to treat S. aureus colonized in the nares before surgery, there have been reports of emerging mupirocin resistance as well as decreased rates of compliance due to the medication needing to be applied by the patient for 5 days before surgery (Phillips et al., 2014). In a study by Ramos et al. (2011), it was noted via a patient survey that while $94 \%$ of patients used the chlorhexidine soap as prescribed before surgery, only $86 \%$ actually applied the mupirocin ointment to their nares as prescribed and $8 \%$ of patients found that it was hard or very hard to purchase the mupirocin ointment due to its' cost. Therefore, other alternatives to mupirocin have been investigated and intranasal povidone-iodine has shown promising results.

Nasal colonization depends on many factors including host defenses, environmental, bacterial, and exposure to S. aureus, but once a person is colonized it places them at increased risk for subsequent infections. It is recommended that patients undergo decolonization of the nares prior to surgery to prevent post-operative surgical site infections. Treatment with mupirocin to both nares for five days before surgery has been recommended but current studies are being performed evaluating the efficacy of intranasal povidone-iodine administered in the hours before surgery as another alternative. The effectiveness of intranasal mupirocin versus intranasal povidone-iodine are compared in this integrative review.

\section{Treatment of Nasal Colonization with Povidone-Iodine}

Povidone-iodine was discovered in 1812 by a chemist from France and was first documented for use as an antiseptic on wounds in 1839 (Zinn et al., 2010). Iodine is currently available in the form of povidone-iodine (PVP-I) or cadexomer iodine. As 
cadexomer iodine has been reported to cause transient patient discomfort with its' use, PVP-I is frequently used (Campbell \& Campbell, 2013). Iodine is the bactericidal component of PVP-I combined with polyvinylpyrrolidone (povidone) which is a synthetic polymer and is commonly found in a $10 \%$ solution in water, yielding $1 \%$ available iodine (Burks, 1998).

Iodine is an essential element and has a long history as a disinfectant and antibacterial sterilizing agent, especially in surgical skin preparation. The $3 \mathrm{M}$ company began marketing a skin and nasal antiseptic preparation (SNP) based on povidone-iodine (PVP-I) as an alternative to mupirocin in 2010 (Uchiyama et al., 2019). Povidone-iodine has rapid in vitro activity and the duration of the effect on the skin can last 12-14 hours due to a process called back diffusion (Anderson et al., 2015). In a study by Anderson et. al (2015), it was concluded that the 3M company's SNP achieves a significant reduction in the resident $\mathrm{S}$. aureus from the anterior nares of human test subjects.

Iodine demonstrates rapid and broad-spectrum bactericidal activity within 10-20 seconds and there is no evidence that bacteria can develop resistance to iodine since it reacts rapidly with double-bonds, amino groups, and solphydral groups, resulting in simultaneous action against multiple molecular targets to cause cell death (Uchiyama et al., 2019). Povidone-iodine works by releasing free iodine which binds to the bacteria (Zinn et al., 2010). Povidone-iodine is rapidly microbicidal with multiple mechanisms of action which include binding to proteins, nucleotides, and cell membrane fatty acids which all disrupt cell function (Campbell \& Campbell, 2013). This mechanism of action coupled with the rapid action of iodine give iodine its' ability to avoid drug resistance. Iodine has excellent microbicidal activity because it has a very broad spectrum of action. 
It is the only topical antimicrobial agent that is effective against both gram-positive and gram-negative organisms, spores, amoebic cysts, viruses, fungi, protozoa, yeasts, and MRSA (Campbell \& Campbell).

Studies involving the use of povidone-iodine to treat nasal colonization with S. aureus in the prevention of SSIs have emerged due to growing mupirocin resistance, cost of the drug, and improper usage by patients. In the search for alternatives to mupirocin, povidone-iodine has gained increased interest because it is a broad-spectrum antiseptic that is suitable for the suppression of S. aureus (Phillips et al., 2014). In contrast to mupirocin ointment intranasally to eradicate S. aureus in the nares before surgery, applying povidone-iodine to the nares one time just prior to surgery is intended to transiently suppress S. aureus in the nares during surgery (Phillips et al.). Therefore, with the use of povidone-iodine, user error is removed as the nurse would be applying the solution before surgery; this would also potentially lower cost.

Next, the theoretical framework used to guide this integrative review will be presented. 


\section{Theoretical Framework}

The purpose of a theoretical framework is to create boundaries for a project, create a structure within the boundaries, define concepts used, increase efficiency in the project, create organization, and provide consistency (Bonnel \& Smith, 2018). The theoretical framework chosen for this integrative review is the Iowa Model of EvidenceBased Practice. This model was first developed in 1994 by a team of nurses from the University of Iowa Hospitals and Clinics (UIHC) to guide clinicians in evaluating and infusing research findings into patient care (Iowa Model Collaborative, 2017). The Iowa Model was revised in 2001 to reflect the evolution into evidence-based practice (EBP) involving multiple levels of evidence (Iowa Model Collaborative, 2017). It was again revised in 2015 to reflect even more dramatic changes in health care. The Iowa Model version from 2015 will be used for the purposes of this integrative review.

The Iowa Model is comprised of a flow chart (Figure 1) which consists of: identify triggering issues/opportunities; assemble, appraise, and synthesize body of evidence; design and pilot the practice change; and integrate and sustain the practice change. Underneath each phase there are sub-headings with further considerations. After each phase, there is a question to determine if the user should continue on with the question or consider another opportunity. An important part of the Iowa Model worth noting comes after the identify triggering issues/opportunities phase, where the question or purpose of the investigation must be stated. This is used to conduct a literature search for research studies that pertain to the question at hand (Brown, 2014). 
The lowa Model Revised: Evidence-Based Practice to Promote Excellence in Health Care

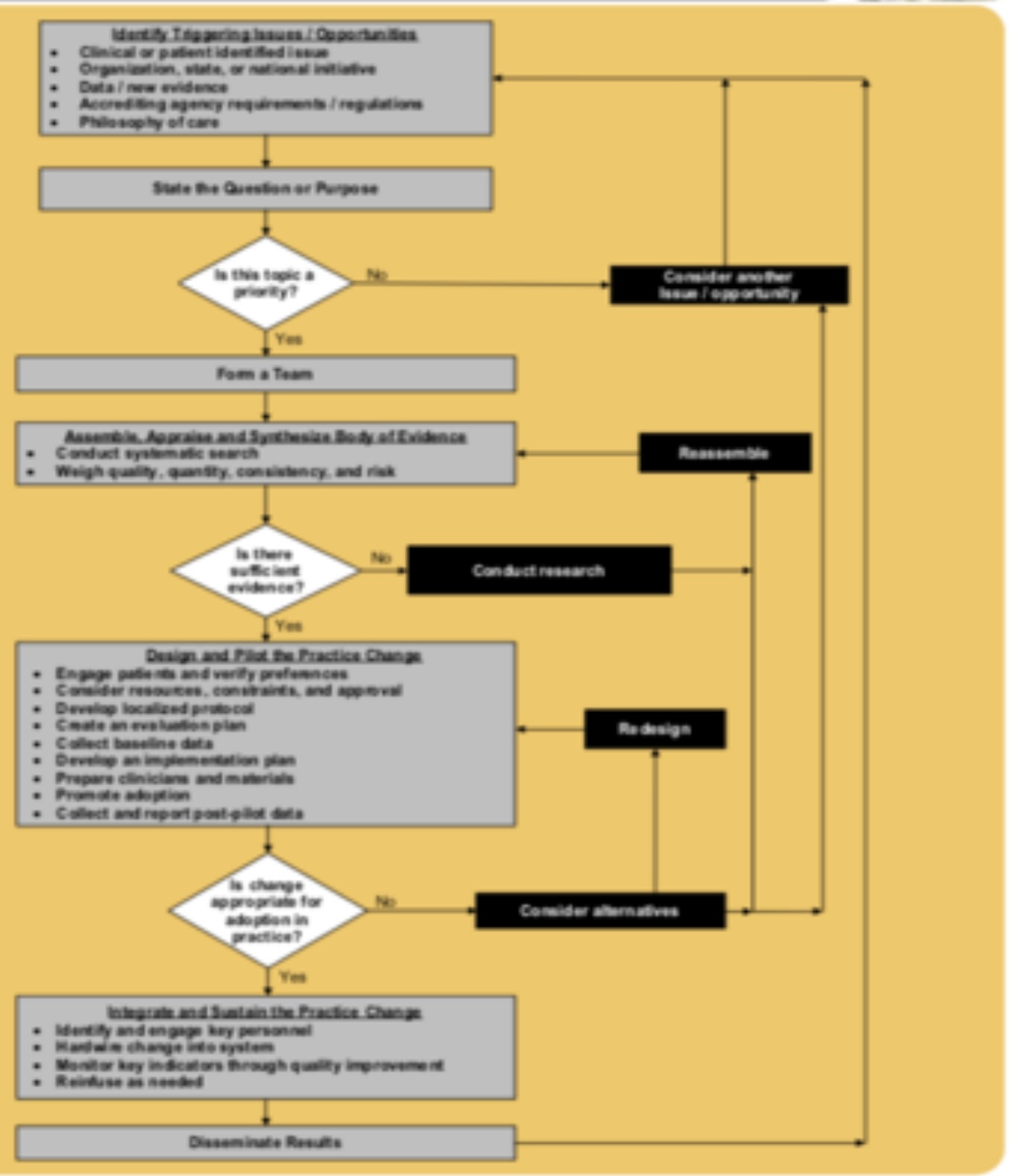

Figure 1. The Iowa Model flow chart. This figure illustrates the 4 phases to use evidence-based practice to promote health care.

Next, the methods to be used in this integrative review will be presented. 


\section{Methods}

\section{Purpose of Study/Clinical Question}

The purpose of this project was to conduct an integrative review to examine the effectiveness of nasal mupirocin vs. nasal povidone-iodine administered pre-operatively for the treatment of a MRSA/MSSA infection to prevent the incidence of post-operative infection.

The question posed was: What is the effectiveness of mupirocin vs. iodine administered nasally pre-operatively at preventing post-operative infections?

\section{Outcomes Examined}

The outcomes examined were development of a post-operative infection, decolonization of MSSA/MRSA, and cost effectiveness of povidone-iodine.

\section{Inclusion and Exclusion Criteria}

Inclusion criteria included: adult patients 18 years and older; colonization with MRSA/MSSA in the nares pre-operatively; nasal colonization confirmed via nasal swab; inpatient and outpatient surgical patients; measurement of post-operative infection as an outcome; measurement of MRSA/MSSA rates as an outcome; quantitative studies and literature reviews comparing the effectiveness of mupirocin versus povidone-iodine published from January 2014-January 2020; quantitative studies and literature reviews related to the effectiveness of mupirocin; and quantitative studies and literature reviews related to the effectiveness of povidone-iodine. Exclusion criteria included: quantitative 
studies and literature reviews before January 2014 and those not meeting the inclusion criteria were excluded.

\section{Search Strategy}

The databases searched included PubMed, CINAHL, and Google Scholar. The terms searched included: Nasal eradication with mupirocin and prevention of postoperative infection and nasal eradication with povidone iodine and prevention of postoperative infection. The selection of research articles was guided by the Preferred Reporting Items for Systematic Reviews and Meta-Analyses (PRISMA) flow diagram (Figure 2). The flow diagram, as illustrated on the next page, was used to document the studies and the process of selection to be used in the review. The flow diagram identified the literature search, the number of records identified, the number of records screened and excluded, and the number of studies included (Moher et al., 2009). The records that did not meet the inclusion criteria and duplicates were excluded. The final result was a total of 6 articles included in this integrative review. 


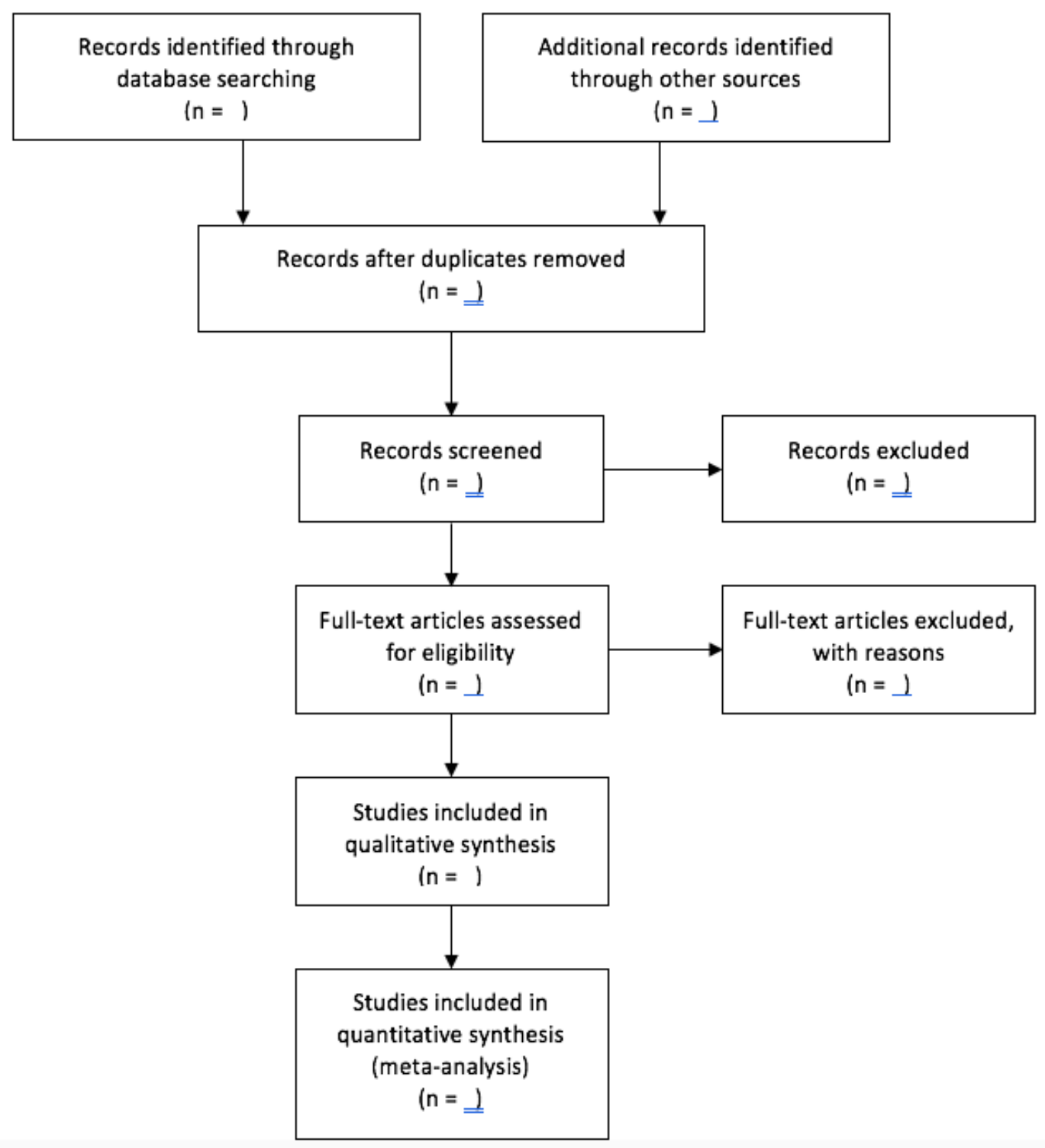

Figure 2. The PRISMA flow diagram. This figure illustrates the number of records identified, included, excluded, and reasons for exclusion.

\section{Data Collection and Appraisal}

The tools used for the data collection and critical appraisal of the included studies were Polit and Beck's Guide to an Overall Critique of Qualitative Research, Quantitative Research Report, and Literature Reviews (2017). For the purposes of this integrative 
review the quantitative and literature review guidelines were utilized. Tables reflecting the critiques of the quantitative research studies are presented in Appendix A.

The quantitative review guidelines consisted of six major headings including the title, abstract, introduction, method, discussion, and general issues. The introduction included sub-headings such as statement of the problem, hypotheses, literature review, and theoretical framework. The method section included protection of human rights, research design, population and sample, data collection and measurement, procedures, data analysis, and findings. The discussion section included interpretation of the findings and implication/recommendations. General issues addressed presentation, researcher credibility, and summary assessment. Each sub-heading had one or more critiquing questions associated with it.

The literature review guideline consisted of seven critiquing questions: how thorough the review was; the sources the review relied on; if key studies were critically appraised; the organization of the review; objectiveness of the review; if the review was part of a research report for a new study; and if the article drew reasonable conclusions about practice implications.

Data collection was performed using a data collection tool created specifically for this review (Table 1). This collection tool provides detailed, pertinent information on each research study involved in this integrative review and includes the purpose, methods, and results of each research article. Tables reflecting the results of the data collection tool can be found in Appendix B. 
Table 1

Data Collection Tool: Background Information

\begin{tabular}{|l|l|l|}
\hline Purpose & Methods & Results \\
\hline & & \\
\hline & & \\
\hline
\end{tabular}

\section{Cross Study Analysis}

Cross study analysis was performed using descriptive data synthesis. This was attained in a narrative form to summarize and compare each study as well as to identify common findings. A table was created to help visualize the findings across the studies (Table 2). Throughout the cross study analysis, patterns and themes were identified as well as commonalities and differences. Tables reflecting the cross-study analysis can be found in Appendix C.

Table 2

Data Collection Tool: Cross Study Analysis

\begin{tabular}{|l|l|}
\hline Author & \\
\hline Key Findings & \\
\hline Recommendations & \\
\hline
\end{tabular}

Next, the results of this integrative review will be presented. 


\section{Results}

The term "nasal eradication with mupirocin and prevention of post-operative infections" was searched and yielded 6,820 results on Google Scholar, Cinahl yielded 453 results, and PubMed yielded 0 results. After narrowing date of publication to between the years of 2014-2020, Google Scholar yielded 3,220 results and Cinahl yielded 148 results. After filtering out articles that were not available in full text, four results met the inclusion criteria on Google Scholar and one from CINAHL.

When the term, "nasal eradication with povidone-iodine and prevention of postoperative infection" was searched and yielded 7,190 results on Google Scholar, 1,047 results on CINAHL, and 0 results on PubMed. After narrowing the date of publication to between the years of 2014-2020, Google Scholar yielded 3,190 and CINAHL yielded 398 results. After filtering out articles that were not available in full text, six articles met the inclusion criteria on Google Scholar and two articles on CINAHL. After filtering out duplicate articles from each search, a total of six articles were included in this integrative review. The PRISMA flow diagram on the next page illustrates the search strategy. 


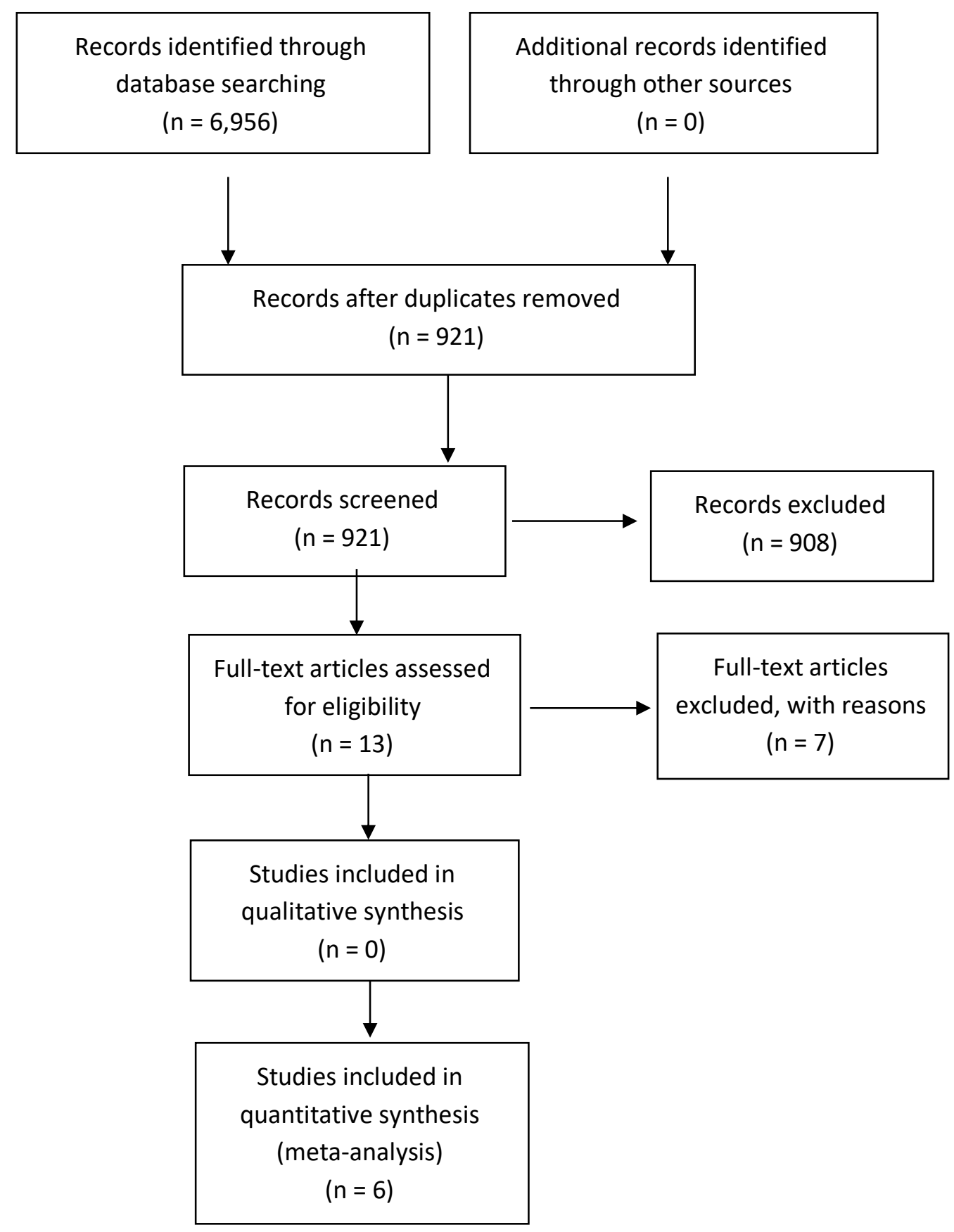

Figure 3. PRISMA flow diagram. This figure illustrates the process for selecting the studies to be used in a systematic review. 
Results for this integrative review will be presented in order from earliest date of research. Tables consisting of critiques from each study reviewed are presented in Appendix A.

Phillips et al. (2014) (Appendix A-1) conducted an investigator initiated, prospective, open label, randomized trial comparing SSI after arthroplasty or spine fusion in patients receiving topical $2 \%$ chlorhexidine gluconate wipes with either twice daily application of mupirocin $2 \%$ ointment for five consecutive days prior to surgery or two 30 second applications of povidone iodine 5\% solution into each nostril within two hours of surgical incision. The study end point was SSI within three months following surgery caused by any pathogen.

This study was performed from March 2011 through March 2012 and subjects were at least 18 years old who were having primary or revision arthroplasty and spine fusion surgery. Subjects were stratified by arthroplasty or spine fusion surgery and then randomized equally to either the mupirocin or povidone iodine treatment groups. The two intervention groups received two applications of six chlorhexidine wipes to the skin from the chin to toes, received appropriate perioperative antimicrobial prophylaxis, and either 7-10 applications of mupirocin to the nares over the five days prior to surgery or two applications of povidone iodine to each nostril within two hours of surgical incision.

The findings are presented in Appendix B-1. Phillips et al. (2014) conducted a 12month enrollment period and 1,874 of the 1,903 patients assessed were enrolled and randomized, 177 of which did not receive the study intervention due to the surgery being cancelled or the actual surgical procedure performed was not eligible for inclusion in this 
study. An SSI caused by any deep surgical site infection developed in 14 of 855 surgeries in the mupirocin group $(n=855)$ and six of 842 surgeries in the povidone iodine group $(n=842)(p=0.1)$. In the per protocol analysis, 13 of 763 subjects in the mupirocin group developed any deep surgical site infection $(n=763)$, compared to 5 of 776 subjects in the povidone iodine group $(n=776)(p=0.06)$. Deep surgical site infection caused by $\mathrm{S}$. aureus occurred in 5 of 855 subjects in the mupirocin group $(n=855)$ and 1 of 842 subjects in the povidone iodine group $(n=842)(p=0.2)$ in the intent to treat group. The intent to treat group included those who were enrolled and met eligibility requirements for the study but did not complete the assigned study regimen. In the per protocol group, 5 of 763 subjects in the mupirocin group developed a deep surgical site infection caused by $S$. aureus $(n=763)$ and 0 of 776 subjects in the povidone iodine group $(n=776)(p=$ $0.03)$.

The authors concluded that povidone iodine is preferred due to its' ease of use and high compliance rates. Povidone iodine is given just prior to surgery by a medical professional, therefore reducing the risk for patient error. Mupirocin, on the other hand, is administered at home by the patient prior to surgery, leaving room for patient error or noncompliance. At $\$ 20$ per application, povidone iodine provides more value, defined as quality of outcomes divided by cost, as compared to mupirocin at $\$ 130$ per course.

Anderson et al. (2015) (Appendix A-2) conducted a quantitative study to examine the efficacy of nasal povidone iodine treatment in explant models and human subjects in the decolonization of nasal S. aureus. Baseline nasal swab samples of the anterior nares were taken from healthy human subjects $(n=70)$ prior to application of povidone iodine or saline. Only subjects with baseline levels of $>5 \mathrm{X} 10(3) \mathrm{CFU} / \mathrm{swab}$ were included in 
this study. Subjects either applied the povidone iodine solution to their nostrils or the $0.9 \%$ saline control to the nostril for 30 seconds each, followed by an immediate repeat application. Swabs were repeated one hour, six hours, and 12 hours after application of the povidone iodine or $0.9 \%$ saline control.

Anderson et al. (2015) (Appendix B-2) compared the antimicrobial effect of povidone iodine to bactroban nasal on 10 Mup MRSA isolates, both high-level resistance and low-level resistance, of ex vivo porcine vaginal mucosa was evaluated. Statistical results showed that the povidone iodine treated explants had significantly less MRSA bacteria than untreated controls and bactroban nasal treated explants $(1.63+/-0.44$ versus $5.30+/-0.30$ and $5.71+/-0.57)$, respectively. The low-level MRSA isolates $(\mathrm{n}=4)$ at 1 hour post application yielded a $\mathrm{p}$-value of $<0.05$. The high-level MRSA isolates $(\mathrm{n}=6)$ at 1 -hour post application yielded a $p$-value of $<0.05$. These values were the same at 6 and 24 hours post application.

The efficacy of povidone iodine on normal flora in the anterior nares of human subjects was also evaluated. Baseline samples $(\mathrm{n}=70)$ were obtained by swabbing the anterior nares. The anterior nares were sampled at one, six, and 12 hours following application of povidone iodine $(n=13-18)$ or saline control $(n=7-9)$. At all three points, S. aureus reduction from the baseline level in povidone iodine treated subjects was significantly greater than the saline control subjects $(2.3+/-1.68$ versus $0.86+/-0.73$ at $1 \mathrm{~h} ; 2.79+/-1.52$ versus $0.76+/-0.58$ at $6 \mathrm{~h}$; and $2.37+/-1.77$ versus $0.6+/-0.9$ at $12 \mathrm{~h}[\mathrm{p}=$ $<0.05])$. 
The authors found that when using the ex vivo porcine vaginal mucosal model, treatment with povidone iodine was bactericidal against MRSA within two hours of application. The explants treated with the $2 \%$ mupirocin ointment showed no change in the MRSA burden 14 hours post application, which is consistent with its' slow mode of action, requiring it to be applied for five consecutive days before surgery. This contributes to patient noncompliance. Furthermore, treatment with povidone iodine resulted in sustained bactericidal activity for up to eight hours after application likely as a result of increased adhesion to the mucus on the tissue surface.

The authors concluded that treatment with povidone iodine showed a significant reduction in S. aureus from the anterior nares of human test subjects as well as ex vivo human skin models. Therefore, due to medication non-compliance, evolving mupirocin resistance, and the need to reduce the risk of S. aureus SSIs, povidone iodine should be considered as an alternative to nasal mupirocin due to its rapid efficacy, broad-spectrum activity against multiple opportunistic pathogens, lack of development of antimicrobial resistance, and ease of use.

Bebko et al. (2015) (Appendix A-3) performed a prospective, retrospective review of de-identified clinical data study at the Michael E. DeBakey Veterans Affairs Medical Center (MEDVAMC). The study was performed to assess the effect of a decontamination protocol on SSIs. The protocol consisted of the application of chlorhexidine washcloths $2 \%$ and oral rinse $0.12 \%$ the night before and the morning of the day of surgery along with the intranasal povidone-iodine solution $5 \%$ once on the morning of the day of surgery for patient undergoing elective orthopedic surgery with hardware implantation. 
The orthopedic service was chosen for this study because they were a high outlier with regard to SSI rates. This decontamination protocol was implemented in May 2013. Patients operated on from October 1, 2012 to April 30, 2013 were part of the control group and those operated on from May 1, 2013 to December 31, 2013 were the intervention group. All patients were monitored for 30 days postoperatively. There was a total of 344 patients in the control group and 365 patients in the intervention group.

The results (Appendix B-3) of the study revealed 3.8\% or thirteen surgical site infections $(n=344)$ in the control group and $1.1 \%$ or four surgical site infections in the intervention group $(n=4), p$-value $=.02$. Of the control group $(n=344)$, seven were superficial SSIs, five were deep SSIs, and one was an organ/space SSI. Of the intervention group $(n=365)$, two were superficial SSIs, two were deep SSIs, and zero were organ/space SSIs. There was a significant reduction in the number of SSIs $(69.2 \%)$ $(p=.02)$ after the decontamination protocol. Furthermore, decontamination was an independent protective factor against the development of an SSI (95\% CI, 0.08-0.77) $(p=.02)$. The data also showed a significant reduction in MRSA nasal carrier status in the intervention group compared with the control group with only 5 positive MRSA swabs in the intervention group $(n=365)$ and 14 positive MRSA swabs in the control group $(n=$ 344) $(p=.05)$.

This was a two-day protocol and there was a 100\% adherence rate. The authors noted that wider implementation of a regimen without the need for $\mathrm{S}$. aureus carrier identification and selective decolonization would allow for cost savings if implemented broadly. While this study was promising, it should be further evaluated through largescale randomized controlled clinical trials. 
Sai et al. (2015) (Appendix A-4) conducted a retrospective cohort study to evaluate the effectiveness of two decolonization protocols for newly diagnosed MRSA colonization in patients and to assess the impact of decolonization on the rate of MRSA infection. The study was performed at an 864-bed academic hospital in Brussels, Belgium. There was a MRSA surveillance and control program in place since 1990 and screening for MRSA via swabbing of the anterior nares and throat was routinely performed on patients with a prior history of MRSA colonization, who have been hospitalized or received antibiotics in the last six months, were admitted from other hospitals or long-term care facilities, or patients with wounds, skin lesions, or foreign material. The study included MRSA-positive patients from January 2006-June 2010.

The decolonization treatments consisted of the application of intranasal mupirocin $2 \%$ and washing with chlorhexidine soap or the application of intranasal povidone-iodine and washing with povidone-iodine soap, with each treatment lasting for five days. The mupirocin/chlorhexidine soap was used for uncomplicated cases and the povidone-iodine was used for complicated cases. Patients were swabbed every 48 hours and at least three successive nose and throat swabs that were negative were required before the patient could be discharged.

There were a total of 1150 patients admitted to the hospital that were colonized with MRSA over the study period but only 268 patients were eligible for the study. The findings are presented in Appendix B-4. Overall, 104 of the 268 patients were successfully decolonized and 164 patients were not. The success rate of the mupirocin/chlorhexidine intervention group was $56 \%$ and the success rate of the povidone-iodine group was $23 \%$. It should also be noted that the use of povidone-iodine 
was restricted to the complicated cases. Of the patients with $>2$ wound sites, 38 had successful decolonization $(n=104)$ and 90 had unsuccessful decolonization $(n=164)$. Of those who were only colonized in their nose, 30 had successful decolonization $(n=104)$ and only 11 had unsuccessful decolonization $(n=164)$.

This particular study demonstrated an overall MRSA decolonization rate that was lower than previously published studies. This was attributed to patients with less than ideal prognostic factors such as chronic wounds who are commonly excluded from similar studies. This study was also limited by the number of patients that did not qualify for the study due to a short length of hospital stay. While the success rate of decolonization was not high in this study, the authors recommended continuation of the identified strategy due to the effectiveness of decolonization on the infection rate.

Peng et al. (2018) (Appendix A-5) conducted a prospective, cross-sectional study conducted at the Department of Orthopedics at Peking Union Medical College Hospital. It was conducted between August 2015 and February 2016 for patients undergoing joint arthroplasty and spine fusion procedures requiring at least three days overnight in the hospital. The aim of the study was to assess the prevalence of MSSA/MRSA in eligible patients with a secondary aim of determining whether the current treatment protocols result in successful decolonization of MSSA/MRSA.

Patients were screened for nasally for MSSA/MRSA within 24 hours of admission by swabbing the anterior nares and then re-swabbing the day of surgery. Those who were positive for MSSA/MRSA underwent the decolonization procedure which consisted of $5 \%$ povidone-iodine nasal swabs in both nostrils twice a day for five days 
prior to surgery, performed by a nurse. Patients were also instructed to take chlorhexidine gluconate baths for five days before surgery. Those who swabbed negative for MSSA/MRSA were not decolonized. Five hundred forty-five patients were screened for MRSA and MSSA and a total of 578 elective procedures were performed during that period. Of those screened, 64 were MSSA carriers and eight were MRSA carriers; therefore 72 patients were treated with $5 \%$ povidone-iodine nasal swabs for decolonization.

Findings by Peng et al. (2018) (Appendix B-5) demonstrated that the day of surgery nasal swab screening results revealed none of the patients were positive for MRSA colonization $(\mathrm{p}=<0.000)$, but 11 patients $(2 \%)$ were positive for MSSA $(\mathrm{n}=545)$, which was a reduction of $92.6 \%$ from the screening before decolonization $(p=<0.001)$. The eradication of MSSA colonization was $94 \%(n=545)$ while the eradication of MRSA colonization was $100 \%(n=545)$. The results were positive showing that this decolonization protocol was less expensive than other protocols and reduced the colonization of MSSA/MRSA in nasal carriers. The authors noted that this treatment was as effective as nasal mupirocin in successfully eradicating MRSA and significantly reducing MSSA.

Urias et al. (2018) (Appendix A-6) performed a retrospective study at a rural hospital with trauma patients undergoing orthopedic operations conducted at a medical center from October 1, 2012 through September 30, 2016. The purpose of the study was to measure the effectiveness of using CHG baths and intranasal povidone-iodine preoperatively and its effectiveness in reducing SSIs. The trauma patients included in this study were those undergoing operative repair of lower extremity fractures using 
hardware. The pre-implementation period took place from October 1, 2012 through September 30, 2014 and the decontamination protocol consisted of bathing patients with 2\% CHG washcloths or Dynahex 4\% CHG solution the night and morning before surgery. The implementation period took place from October 1, 2014 through September 30,2016 and consisted of the decontamination protocol with the addition of intranasal povidone-iodine within one hour of incision.

Over the four years of this study, 1,746 trauma patients underwent a total of 1,892 orthopedic operations to repair fracture of the lower extremities using hardware. The findings (Appendix B-6) indicated there was a significant decrease in the SSI rate from $1.1 \%$ in the pre-intervention group $(n=930)$ to $0.2 \%$ in the intervention group $(n=962)$ $(p=0.020)$. In the pre-intervention group $(n=930)$, of the positive SSIs, 10 were MSSA and 8 were MRSA. Of the intervention group $(n=962)$, two of the SSIs were MSSA and none were MRSA. The annual infection rate for the first year of the study in the preintervention group was $1.5 \%(n=476)$ and $0.7 \%$ for the second year $(n=454)$. The annual infection rate for the first year of the study in the intervention group was $0.2 \%(n=484)$ and $0.2 \%$ in the second year $(n=478)$.

This research study was valuable to a patient population that was not represented in the current literature. This population could not receive intranasal mupirocin before surgery because mupirocin needs to be applied for five days. Since this was emergent surgery, meeting this criteria was not possible. Therefore, intranasal povidone-iodine was a promising option as it only needs to be administered once before surgery. The results of this study demonstrated that intranasal povidone-iodine was not only effective in reducing the rate of SSIs, but also more cost effective. The researchers concluded that 
adding the intranasal povidone-iodine to their decontamination protocol met statistical significance $(p=0.020)$, was cost effective, simple to use, and is widely available to medical professionals.

\section{Cross Study Analysis}

A cross study analysis was conducted and will be summarized next. Tables illustrating the findings and themes of each research study can be found in Appendix C.

A main outcome examined in this integrative review was whether the authors saw a reduction in SSIs following their intervention. Three of the six research studies explored the reduction of SSIs as one of their outcomes (Bebko et al., 2015; Phillips et al., 2014; Urias et al., 2018). All three authors found that their intervention, which consisted of daily CHG baths and intranasal povidone-iodine pre-operatively, resulted in a reduction of post-operative SSIs. Of these three authors, only one, Phillips et al. (2014), examined the use of CHG baths and intranasal povidone-iodine or CHG baths and intranasal mupirocin and impact on post-operative SSIs. These authors found that CHG baths and intranasal povidone-iodine was more effective at reducing SSIs than CHG baths and intranasal mupirocin.

The next outcome examined was the effectiveness of an intranasal decolonization protocol on the reduction of MRSA/MSSA. Research has shown that colonization with MRSA/MSSA in the nares is a risk factor for the development of a post-operative SSI. Therefore, the decolonization of the nares prior to surgery results in lower post-operative SSI rates. Three of the six studies (Anderson et al., 2015; Peng et al., 2018; Sai et al., 2015) studied the effects of a decontamination protocol on the reduction of nasal MRSA 
and/or MSSA and all showed a reduction in nasal MRSA and/or MSSA. Anderson et al. (2015) analyzed the effects of intranasal povidone-iodine on MSSA and found that S. aureus growth was greatly reduced versus the control with the use of intranasal povidoneiodine. Peng et al. (2018) studied the effectiveness of intranasal povidone-iodine and CHG baths on the reduction of MSSA/MRSA and found a significant reduction of MSSA/MRSA post intervention. Sai et al. (2015) examined intranasal mupirocin with CHG baths versus intranasal povidone-iodine and $\mathrm{CHG}$ baths and their effectiveness against MRSA finding that the povidone-iodine group was not as successful as the mupirocin group, but it was effective in reducing the infection rate.

The final outcome examined was the cost effectiveness of intranasal mupirocin versus intranasal povidone-iodine. Four of the six research studies evaluated the cost of intranasal povidone-iodine versus intranasal mupirocin. All four studies concluded that the use of intranasal povidone iodine is much more cost effective than intranasal mupirocin (Bebko et al., 2015; Peng et al., 2018; Phillips et al., 2014; Urias et al., 2018). All authors noted the cost effectiveness to be due to the lower cost of povidone-iodine swabs and needing less povidone-iodine swabs versus mupirocin swabs.

There were several limitations noted in each study. All studies noted generalizability of the study as a limitation (Anderson et al., 2015; Bebko et al., 2015; Peng et al., 2018; Phillips et al., 2014; Sai et al., 2015; Urias et al., 2018) as they were conducted at one institution and with specific patient populations. One study noted that their positive results could be underestimated due to a short follow-up period (Bebko et. al., 2015). A study by Peng et al. (2018) noted that they opted for culture swabs instead of PCR swabs due to cost, but the PCR swabs would have been more sensitive. Urias et 
al. (2018) noted that they chose not to culture patients pre or post intervention to test the efficacy of the intranasal povidone-iodine. Five out of the six studies noted the need for more randomized control trials (Anderson et al., 2015; Bebko et al., 2015; Peng et al., 2018; Sai et al., 2015; Urias et al., 2018) as they were either retrospective, crosssectional, or prospective. Finally, all authors noted the need for larger studies (Anderson et al., 2015; Bebko et al., 2015; Peng et al., 2018; Phillips et al., 2014; Sai et al., 2015; Urias et al., 2018).

Next, the summary and conclusions will be presented. 


\section{Summary and Conclusions}

Surgical site infections have long been an unwanted complication of all types of surgical procedures. In the forefront of SSI research, many efforts have been focused on orthopedic surgeries. Mupirocin administered intranasally for five days before surgery has been a commonly used preventative to post-operative SSIs and has been shown to be effective by multitudes of clinical studies. However, there are concerns of rising mupirocin resistance, increased cost, and user error surrounding the use of intranasal mupirocin. For this reason, intranasal povidone-iodine is being investigated as another alternative. At this time, it does not have resistance, is cost effective, and is administered by a healthcare practitioner, significantly reducing user error.

The purpose of this integrative review was to evaluate the effectiveness of intranasal mupirocin versus intranasal povidone-iodine and its effectiveness in reducing nasal MRSA/MSSA colonization to prevent post-operative SSIs. After a thorough review of all relevant literature, research studies were compared to evaluate the effectiveness of intranasal povidone-iodine versus intranasal mupirocin on the rate of post-operative SSIs. By performing this comprehensive literature review, important research was compiled, and relevant outcomes were evaluated. The Iowa Model of Evidence-Based Practice was used to guide this integrative review. A thorough literature review was implemented which explored the use of intranasal povidone-iodine as an alternative to intranasal mupirocin in the prevention of SSIs. Following the literature review, an in-depth search on the use of intranasal mupirocin and intranasal povidone-iodine was explored. Search strategies and key words searched are located in the methods section. The PRISMA flow diagram was used to guide the selection of the research studies included in this 
integrative review. All research studies that were used in this integrative review are examined in the results section. A brief review of those studies' findings will be presented next.

Phillips et al. (2014) published the only randomized control trial on the use of nasal mupirocin ointment versus intranasal povidone-iodine solution to date. The researchers found that the use of intranasal mupirocin was similar in efficacy to preoperative intranasal povidone-iodine in preventing S. aureus SSI after arthroplasty and spine fusion surgery. Participants in the povidone-iodine intervention group were noted to have lower rates of treatment related symptoms and greater compliance as it was applied by a healthcare provider. Phillips et al. (2014) concluded that nasal povidone-iodine may be considered as an alternative to mupirocin to reduce the incidence of SSIs.

Anderson et al. (2015) performed a study to examine the efficacy of povidoneiodine in the prevention of MRSA infections in an ex vivo model, ex vivo human skin model, and in the anterior nares of human subjects. In all models studied, the povidoneiodine groups had significantly persistent reduced or undetectable bacterial densities, much greater than the mupirocin groups. The effectiveness of povidone-iodine on normal flora of the anterior nares in human subjects $(\mathrm{n}=70)$ was observed and it was discovered that $\mathrm{S}$. aureus was significantly reduced from baseline level than the saline control subjects. It was concluded that the benefits of povidone-iodine should be considered in the prevention of SSIs as well as evolving mupirocin resistance and issues with medication compliance. 
Bebko et al. (2015) performed a prospective clinical study on the effectiveness of a decontamination protocol consisting of chlorhexidine washcloths and chlorhexidine oral rinse the night before and the morning of orthopedic surgery in addition to intranasal povidone-iodine once the morning of surgery $(n=344)$. The control group consisted of patients who did not receive a decontamination protocol $(n=365)$. The results indicated that the SSI rate in the intervention group was significantly lower than that in the control group. Methicillin resistant staphylococcus aureus was identified as an independent predictor of developing an SSI. Povidone-iodine was supported as an attractive alternative to SSI prevention due to its efficacy, cost-effectiveness, and fewer concerns about antibiotic resistance.

Sai et al. (2015) performed a retrospective cohort study to evaluate the effectiveness of two decontamination protocols on positive MRSA carriers. The chlorhexidine group had a $56 \%$ success rate and the povidone-iodine group had a $23 \%$ success rate. The authors concluded that intranasal mupirocin was more effective than intranasal povidone-iodine, but they did note that the povidone-iodine was implemented on the complicated cases. While the researchers did not demonstrate a high success rate, they concluded that the effectiveness of decolonization on infection rates justified the continuation of a decontamination protocol.

Peng et al. (2018) conducted a prospective cross-sectional study to assess the prevalence of MSSA/MRSA in patients undergoing elective orthopedic surgery as well as to determine whether their current treatment protocols resulted in the successful decolonization of MSSA/MRSA. The results showed successful eradication of MRSA and significantly reduced colonization of MSSA. The researchers concluded that the use 
of intranasal povidone-iodine was as effective as intranasal mupirocin and more cost effective.

Urias et al. (2018) performed a retrospective review evaluating the effectiveness of two decontamination protocols to reduce SSIs in urgent lower extremity repairs. The results were statistically significant, with a decrease in SSIs from $1.1 \%$ in the preintervention group to $0.2 \%$ in the intervention group, which included the use of povidone-iodine. The researchers recommended the use of intranasal povidone-iodine for its efficacy, cost-effectiveness, ease of use, and wide availability.

Throughout this integrative review, three out of the six studies showed increased effectiveness of povidone-iodine versus mupirocin in the reduction of SSIs (Bebko et al., 2015; Phillips et al. 2014; Urias et al., 2018). Three out of the six studies found a significant reduction in MRSA/MSSA colonization with the use of intranasal povidoneiodine versus mupirocin (Anderson et al., 2015; Peng et al., 2018; Urias et al. 2018). Overall, five out of the six studies found that statistically significant results proving that intranasal povidone-iodine was as effective or more effective than intranasal mupirocin (Anderson et al., 2015; Bebko et al., 2015; Peng et al., 2018; Phillips et al., 2014; Urias et al., 2018). One research study found a low success rate in the reduction of MRSA/MSSA with the use of intranasal povidone iodine, but did show effectiveness (Sai et al., 2015). Four of the six studies showed that intranasal povidone-iodine was more cost effective than intranasal mupirocin (Bebko et al., 2015; Peng et al., 2018, Phillips et al., 2014; Urias et al., 2018). 
This review yielded largely positive evidence that the use of intranasal povidone iodine is effective in reducing the rate of SSIs, MRSA and MSSA. There are several limitations to this integrative review to be acknowledged. Unfortunately, there was only one randomized control trial found during the literature search, with the other studies being cross-sectional, prospective, or retrospective. Therefore, there is a need for larger randomized control trials to further support the current clinical evidence that intranasal povidone-iodine is just as effective, if not more effective, than intranasal mupirocin in the prevention of SSIs. Additionally, a majority of these research studies included chlorhexidine baths in their decolonization protocol, which may have attributed to the decrease in SSIs.

In conclusion, intranasal povidone-iodine is an attractive alternative to intranasal mupirocin in the fight against SSIs, as has been supported in the aforementioned research studies. The use of povidone-iodine has been shown to reduce SSIs, reduce and/or eradicate MRSA and MSSA, be more cost-effective, reduce mupirocin resistance, reduce non-compliance rates, and be user friendly. Intranasal povidone-iodine is a promising alternative to SSI prevention and consideration by medical professionals should be taken to implement this effective alternative.

Next, the recommendations and implications for advanced nursing practice will be presented. 


\section{Recommendations and Implications for Advanced Nursing Practice}

At the forefront of healthcare decisions and implementations is evidence-based practice (EBP). Evidence based practice is the culmination of research studies that aim to demonstrate the most effective and safe treatment for patients and it is ever changing. One thing that a healthcare provider can always count on is always learning new information and improving upon current practice. What was new, top of the line research just a decade later will be outdated and modified per guidelines from new research. It is for this reason that advanced practice registered nurses (APRNs) must continue to evaluate the newest literature to provide the best care and most up to date treatment guidelines for their patients. This integrative review provided valuable, up to date information based on evidence and provides important guidelines for APRNs.

No matter which specialty an APRN practices in, preventing infection will be one of their top priorities. In the case of surgical patients, it is of utmost importance that the APRN take all possible measures to prevent a post-operative SSI from occurring. Current practice in the prevention of SSIs is up to the discretion of each individual provider and healthcare system. As noted in this integrative review, the use of intranasal povidoneiodine has proven to be just as, if not more, effective than intranasal mupirocin. As an APRN, their job is to give their patients the best care possible. This includes providing them with treatment regimens that are cost-effective, easy to use, effective, and are easy to comply with.

Advanced practice NPs are trained at the masters' level to be able to practice autonomously, which includes diagnosing, ordering labs and tests, and prescribing medications. They are also trained in the leadership role and in the ability to promote 
change within institutions. This leadership role can be used to provide research, education, policy change, and implementation for healthcare workers. This is an important quality of the APRN which could be used to promote a policy change in an institution and implement the use of intranasal povidone-iodine administered preoperatively to further reduce SSI rates.

In order to facilitate policy change, key interdisciplinary team members must be involved. Related to instituting intranasal povidone-iodine in the prevention of SSIs, key interdisciplinary members would include, but not limited to, nursing supervisors, surgeons, infection control, pharmacists, and nursing staff. It is the role of the APRN to present research and evidence-based findings and to provide education to these specialties to promote policy change. Once key team members have agreed to implementation of a new policy, the APRN has the ability develop the new policy and provide the education to implement the new policy change. This role is invaluable to promoting change and providing the best care for patients according to the most up to date research studies. The research compiled in this integrative review can be utilized to create a new policy in the fight against post-operative SSIs.

As previously noted in this integrative review, intranasal mupirocin requires application for five days before surgery which makes it harder for patients to comply with the treatment plan and furthermore, is not possible in more emergent surgeries. The use of intranasal povidone-iodine is an attractive alternative because it only needs to be applied once before surgery, therefore it's able to be administered on an urgent basis, and it is applied by a nurse before surgery therefore, patient compliance is eliminated as a risk 
factor. The APRN will be able to provide research and education to nurses on the proper administration of intranasal povidone-iodine.

Education is a valuable role of the APRN. Of specific value are the years of experience the NP has in also being a registered nurse. Due to this background, the NP has the valuable trait of being more like a peer to the nurse rather than an authority figure. This puts the NP in a strategic position to be able to relate to the nurse and gain valuable trust, enabling an open relationship where the nurse and APRN can feel comfortable and free to learn from each other. This trust and understanding, as well as the advanced education of the APRN, provides a conducive environment for education. With the APRN's advanced degree, they are also able to educate other healthcare providers. This includes fellow mid-levels, physicians, and surgeons.

Before education is administered, research must occur. Research is the start of all evidence-based practice and is the avenue for policy change. Another valuable asset of the APRN is being able to attain, interpret, and disseminate valuable new information attained from the latest research studies. Evidence-based practice is constantly evolving and will always remain an important part of the APRN role. As noted in this integrative review, there needs to be further research on the use of intranasal povidone-iodine versus intranasal mupirocin. Once the APRN gathers and critiques all of the evidence from research, it can be disseminated to colleagues and then assist in providing education and training for practice.

While this integrative review showed very promising results in using intranasal povidone-iodine to prevent SSIs, further research is needed. Unfortunately, there is only 
one randomized control trial evaluating the effectiveness of intranasal povidone-iodine versus intranasal mupirocin in the prevention of SSIs. Therefore, further randomized control trials and studies with larger sample sizes are needed. The APRN is in a valuable position to be able to implement a research study at their own institution and create definitive practice guidelines.

An important consideration for APRNs is the cost of the medications they order for their patients. Patients have many different economic backgrounds, and some don't even have insurance. In order for patients to take their medications, they need to first be able to afford them. Several articles in this integrative review found that intranasal povidoneiodine is more cost-effective than intranasal mupirocin, which is an important consideration to make when ordering medications to prevent SSIs.

When the NP is choosing a better alternative for patients in the prevention of SSIs, it is important that the treatment they choose is effective. Of the six articles presented in this integrative review, all showed the effectiveness of intranasal povidoneiodine. Despite the results presented in the article by Sai et al. (2015) that showed a low success rate at the eradication of MSSA/MRSA decolonization, intranasal povidoneiodine was effective in lowering infection rates. With all of these research studies included in this review showing positive results, it is recommended that the use of intranasal povidone-iodine be considered by the APRN for use in the prevention of SSIs.

Advanced practice registered nurses are in the unique position of having the background of a registered nurse with the capabilities of prescribing and improving patient outcomes. This puts them in an advantageous position to advocate for change and 
have easy access to educating nurses and medical professionals. The APRN is a valuable resource for educating nurses and providers on current evidence-based practice and implementing new practice guidelines and policies for their patient populations. 


\section{References}

Alexander, J. W., Solomkin, J. S., \& Edwards, M. J. (2011). Updated recommendations for control of surgical site infections. Annals of Surgery, 263(6), 1082-1093. doi: 10.1097/SLA.0b013e31821175f8

Alfonso-Sanchez, J. L., Martinez, I. M., Martin-Moreno, J. M., Gonzalez, R. S., \& Botia, F. (2017). Analyzing the risk factors influencing surgical site infections: the site of environmental factors. Can J Surg, 60(3), 155-161. doi: 10.1503/cjs.017916

Al-Tamimi, M., Himsawi, N., Abu-Raideh, J., Jazar, D. A., Al-Jawaldeh, H., Al Haj Mahmoud, S., Hijjawi, N., \& Hawamdeh, H. (2018). Nasal colonization by methicillin-sensitive and methicillin-resistant staphylococcus aureus among medical students. The Journal of Infection in Developing Countries, 12(5), 326335. doi: $10.3855 /$ jidc. 9908

Anderson, D. J., Podgorny, K., Berrios-Torres, S. I., Bratzler, D. W., Dellinger, E. P., Greene, L., Nyquist, A. C., Saiman, L., Yokoe, D. S., Maragakis, L. L., \& Kaye K. S. (2014). Strategies to prevent surgical site infections in acute care hospitals: 2014 update. Infect Control Hosp Epidemiol, 36(6), 605-627. doi:

$10.1086 / 676022$

Anderson, M. J., David, M. L., Scholz, M., Bull, S. J., Morse, D., Hulse-Stevens, M., \& Peterson, M. L. (2015). Efficacy of skin and nasal povidone-iodine preparation against mupirocin-resistant staphylococcus aureus and s. aureus within the anterior nares. Antimicrobial Agents and Chemotherapy, 59(5), 2765-2773. 
Andersson, A. E., Bergh, I., Karlsson, J., Erikkson, B. I., \& Nilsson, K. (2012). The application of evidence-based measures to reduce surgical site infections during orthopedic surgery-report of a single-center experience in Sweden. Patient Safety in Surgery, 6(11), 1-8.

Bandaru, N. R., Rao, R. A., Prasad, V. K., \& Murty, R. (2012). A prospective study of postoperative wound infections in a teaching hospital of rural setup. Journal of Clinical \& Diagnostic Research, 6(7), 1266-1271.

Bebko, S. P., Green, D. M., \& Awad, S. S. (2015). Effect of a preoperative decontamination protocol on surgical site infections in patients undergoing elective orthopedic surgery with hardware implantation. JAMA Surgery, 150(5), 390-395. doi: 10.1001/jamasurg.2014.3480

Berrios-Torres, S. I., Umscheid, C. A. \& Bratzler, D. W. (2017). Centers for disease control and prevention guideline for the prevention of surgical site infection, 2017. JAMA Surg, 152(8), 784-791. doi: 10.1001/jamasurg.2017.0904

Bonnel, W. \& Smith, K. V. (2018). Proposal writing for clinical nursing and DNP projects $\left(2^{\text {nd }}\right.$ ed.). New York, NY: Springer Publishing Company.

Brown, C. G. (2014). The Iowa Model of Evidence-Based Practice to promote quality care: An illustrated example in oncology nursing. Clinical Journal of Oncology Nursing, 18(2), 157-159. doi: 10.1188/14.CJON.157-159

Burks, I. R. (1998). Povidone-iodine solution in wound treatment. Physical Therapy, $78(2), 212-218$. 
Campbell, N. \& Campbell, D. (2013). Evaluation of a non-adherent, povidone-iodine dressing in a case series of chronic wounds. Journal of Wound Care, 22(8), 401406.

Centers for Disease Control and Prevention (CDC) (2019). National Center for Emerging and Zoonotic Infectious Diseases Division of Healthcare Quality Promotion. Retrieved from: www.cdc.gov

Cheng, K., Li, J., Kong, Q., Wang, C., Ye, N., \& Xia, G. (2015). Risk factors for surgical site infection in a teaching hospital: A prospective study of 1, 138 patients. Patient Preference and Adherence, 9, 1171-1177.

Hogan, B., Rakotozandrindrainy, R., Al-Emran, H., Dekker, D., Hahn, A., Jaeger, A., Poppert, S., Frickmann, H., Matthias Hagen, R., Micheel, V., Crusius, S., Heriniaina, J. N., Rakotondrainiarivelo, J. P., Razafindrabe, T., May, J., \& Schwarz, N. G. (2016). Prevalence of nasal colonization by methicillin-sensitive and methicillin-resistant staphylococcus aureus among healthcare workers and students in madagascar. BMC Infectious diseases, 16(420), 1-9. doi: $10.1186 / \mathrm{s} 12879-016-1733-6$

Hussain, M. S., Naqvi, A., \& Sharaz, M. (2019). Methicillin resistant staphylococcus aureus (MRSA); Prevalence and susceptibility pattern of (MRSA) isolated from pus in tertiary care of district hospital of Rahim Yar Khan. The Professional Medical Journal, 26(1), 122-127. doi: 10.29309/TPMJ/2019.26.01.2510

Iowa Model Collaborative (2017). Iowa Model of Evidence-Based Practice: Revisions and validation. Worldviews on Evidence-Based nursing, 14(3), 175-182. 
Kavanagh, K. T., Abusalem, S., \& Calderon, L. E. (2017). The incidence or MRSA infections in the united states: Is a more comprehensive tracking system needed? Antimicrobial Resistance and Infection Control, 6(34), 1-6. doi: 10.1186/s13756017-0193-0

Kim, M. W., Greenfield, B. K., Snyder, R. E., Steinmaus, C. M., \& Riley, L. W. (2018). The association between community-associated staphylococcus aureus colonization and disease: A meta-analysis. BMC Infectious Diseases, 18(86), 111. doi: https://doi.org/10.1186/s12879-018-2990-3

Ko, W., Lazenby, W. D., Zelano, J. A., Isom, O. W., \& Krieger, K. H. (1992). Effects of shaving methods and intraoperative irrigation on suppurative mediastinitis after bypass operations. Ann Thoracic Surg, 53(2), 301-305. doi: 10.1016/00034975(92)91337-9

Kourtis, A. P., Hatfield, K., Baggs, J., Mu, Y., See, I., Epson, E., Nadle, J., Kainer, M. A., Dumyati, G., Petit, S., \& Ray, S. M. (2019). Morbidity and Mortality Weekly Report, 68(9), 214-219.

Loftus, R. W., Dexter, F., \& Robinson, A. D. M. (2018). High-risk staphylococcus aureus transmission in the operating room: A call for widespread improvements in perioperative hand hygiene and patient decolonization practices. American Journal of Infection Control, 46(10), 1134-1141. doi: https://doi.org/10.1016/j.ajic.2018.04.211

Loftus, R. W., Dexter, F., \& Robinson, A. D. M. (2018). Methicillin-resistant staphylococcus aureus has greater risk of transmission in the operating room than 
methicillin-sensitive S aureus. American Journal of Infection Control, 46, 520525. doi: https://doi.org/10.1016/j.ajic.2017.11.002

Moher, D., Liberati, A., Tetziaff, J., Altman, D. G., \& The PRISMA Group. (2009). Preferred reporting items for systematic reviews and meta-analyses: The PRISMA statement. PLOS Medicine, 6(7), 1-6.

National Hospital Inpatient Quality Measures Specifications Manual (NHIQMSM). (2014). Retrieved from: www.qualitynet.org

Owens, C. D. \& Stoessel, K. (2008). Surgical site infections: epidemiology, microbiology, and prevention. Journal of Hospital Infection, 70(52), 3-10.

Peng, H. M., Wang, L. C., Zhai, J. L., Weng, X. S., Feng, B., \& Wang, W. (2018). Effectiveness of preoperative decolonization with nasal povidone iodine in Chinese patients undergoing elective orthopedic surgery: A prospective crosssectional study. Brazilian Journal of Medical and Biological Research, 51(2), 1-6. doi: 10.1590/1414-431X20176736

Perl, T. M., Cullen, J. J., Wenzel, R. P., Zimmerman, M. B., Pfaller, M. A., Sheppard, D., Twombley, J., French, P. P., \& Herwaldt, L. A. (2002). Intranasal mupirocin to prevent postoperative staphylococcus aureus infections. The New England Journal of Medicine, 346, 1871-1877. doi: 10.1056/NEJMoa003069

Phillips, M., Rosenberg, A., Shopsin, B., Cuff, G., Skeete, F., Foti, A., Kraemer, K., Inglima, K., Press, B., \& Bosco, J. (2014). Preventing surgical site infections: A randomized, open-label trial of nasal mupirocin ointment and nasal povidone 
iodine solution. Infection Control Hospital of Epidemiology, 35(7), 826-832. doi: $10.1086 / 676872$

Piechota, M., Kot, B., Frankowska-Maciejewska, A., Gruzewska, A., \& Wozniak-Kosek, A. (2018). Biofilm formation by methicillin-resistant and methicillin-sensitive staphylococcus aureus strains from hospitalized patients in poland. BioMed Research International, 2018, 1-7. doi: https://doi.org/10.1155/2018/4657396

Polit, D. F. \& Beck, C. T. (2017). Nursing research: generating and assessing evidence for nursing practice. $\left(10^{\text {th }}\right.$ ed.). Philadelphia, PA: Wolters Kluwer.

Ramos, N., Skeete, F., Haas, J. P., Hutzler, L., Slover, J., \& Phillips, M. (2011). Surgical site infection prevention initiative patient attitude and compliance. Bulletin of the NYU Hospital for Joint Diseases, 69(4), 312-318.

Rosenberger, L. H., Politano, A. D., \& Sawyer, R. G. (2011). The surgical care improvement project and prevention of post-operative infection, including surgical site infection. Surgical Infections, 12(3), 163-168. doi:

$10.1089 /$ sur.2010.083

Sai, N., Laurent, C., Strale, H., Denis, O., \& Byl, B. (2015). Efficacy of the decolonization of methicillin-resistant staphylococcus aureus carriers in clinical practice. Antimicrobial Resistance and Infection Control, 4(56), 1-8. doi: $10.1186 / \mathrm{s} / 13756-015-0096-\mathrm{x}$

Sakr, J., Bregeon, F., Mege, J. L., Rolain, J. M., \& Blin, O. (2018). Staphylococcus aureus nasal colonization: An update on mechanisms, epidemiology, risk factors, 
and subsequent infections. Frontiers in Microbiology, 9(2419), 1-15. doi:

10.3389/fmicb.2018.02419

Septimus, E. J. \& Schweizer, M. L. (2016). Decolonization in prevention of health careassociated infections. American Society for Microbiology, 29(2), 201-222.

Sfeir, M., Obeid, Y., Eid, C., Saliby, M., Farra, A., Farhat, H., \& Mokhbat, J. E. (2014). Prevalence of staphylococcus aureus methicillin-sensitive and methicillinresistant nasal and pharyngeal colonization in outpatients in Lebanon. American Journal of Infection Control, 42, 160-163. doi: http://dx.doi.org/10.1016/j.ajic.2013.08.008

Stone, P. W., Kunches, L, \& Hirschhorn, L. (2009). Cost of hospital-associated infections in massachusetts. American Journal of Infection Control, 37(3), 210-214. doi: https://doi.org/10/1016/j.ajic.2008.07.011

Surahio, A. R., Talpur, A. A., Memon, A. S., Junejo, A., \& Laghari, A. A. (2017). Surgical site infections: Culture \& sensitivity pattern of micro-organisms isolated in a tertiary care hospital. The Professional Medical Journal, 24(1), 57-63.

Uchiyama, S., Dahesh, S., Nizet, V., \& Kessler, J. (2019). Enhanced topical delivery of non-complexed molecular iodine for methicillin-resistant staphylococcus aureus decolonization. International Journal of Pharmaceutics, 554, 81-86. doi: https://doi.org/10.1016/j.ijpharm.2018.11.004 
Urias, D. S., Varghese, M., Simunich, T., Morrissey, S., \& Dumire, R. (2018). Preoperative decolonization to reduce infections in urgent lower extremity repairs. European Journal of Trauma and Emergency Surgery, 44, 787-793.

Waryah, C. B., Gogoi-Tiwari, J., Wells, K., Eto, K. Y., Masoumi, E., Costantino, P., Kotiw, M., \& Mukkur, T. (2016). Diversity of virulence factors associated with west Australian methicillin-sensitive staphylococcus aureus isolates of human origin. BioMed Research International, 2016, 1-10. doi:

http://dx.doi.org/10.1155/2016/8651918

Yi, J., Liang, H., Song, R., Xia, H., \& Huang, Y. (2018). Maintaining intraoperative normothermia reduces blood loss in patients undergoing major operations: A pilot randomized controlled clinical trial. BMC Anesthesiology, 18(126), 1-7. doi: htpps://doi.org/10.1186/s1287-018-0582-9

Zinn, J., Jenkins, J. B., Swofford, V., Harrelson, B., \& McCarter, S. (2010). Intraoperative patient skin prep agents: Is there a difference? AORN Journal, 92(6), 662-671. doi: 10.1016/j.aorn.2010.07.016 


\section{Appendix A-1}

Phillips, M., Rosenberg, A., Shopsin, B., Cuff, G., Skeete, F., Foti, A., Kraemer, K., Inglima, K., Press, B., \& Bosco, J. (2014). Preventing surgical site infections: A randomized, open-label trial of nasal mupirocin ointment and nasal povidone iodine solution. Infection Control Hosp Epidemiol, 35(7), 826-832

\begin{tabular}{|c|c|c|}
\hline Title & $\begin{array}{l}\text { Is the title a good } \\
\text { one, succinctly } \\
\text { suggesting key } \\
\text { variables and the } \\
\text { study population? }\end{array}$ & $\begin{array}{l}\text { The title was good } \\
\text { in regard to key } \\
\text { variables but only } \\
\text { made reference to } \\
\text { the study population } \\
\text { broadly, stating that } \\
\text { it was a surgical } \\
\text { population. }\end{array}$ \\
\hline Abstract & $\begin{array}{l}\text { Did the abstract } \\
\text { clearly and concisely } \\
\text { summarize the main } \\
\text { features of the report } \\
\text { (problem, methods, } \\
\text { results, } \\
\text { conclusions)? }\end{array}$ & $\begin{array}{l}\text { The abstract was } \\
\text { well written and } \\
\text { clearly and } \\
\text { concisely } \\
\text { summarized the } \\
\text { main features of the } \\
\text { report. The } \\
\text { background clearly } \\
\text { stated the problem } \\
\text { and the methods; } \\
\text { results, and } \\
\text { conclusions sections } \\
\text { were very } \\
\text { informative and } \\
\text { included key } \\
\text { information in the } \\
\text { study. }\end{array}$ \\
\hline $\begin{array}{l}\text { Introduction } \\
\text { Statement of the Problem }\end{array}$ & $\begin{array}{l}\text { Was the problem } \\
\text { stated } \\
\text { unambiguously, and } \\
\text { was it easy to } \\
\text { identify? } \\
\text { Is the problem } \\
\text { statement build a } \\
\text { persuasive argument } \\
\text { for the new study? } \\
\text { Was there a good } \\
\text { match between the } \\
\text { research problem } \\
\text { and the methods } \\
\text { used -that is, was a }\end{array}$ & $\begin{array}{l}\text { The introduction } \\
\text { section introduced } \\
\text { the problem } \\
\text { unambiguously and } \\
\text { it was easy to } \\
\text { identify in the } \\
\text { opening paragraph } \\
\text { with a statement } \\
\text { about surgical site } \\
\text { infection rates. A } \\
\text { persuasive argument } \\
\text { was built for this } \\
\text { study by providing } \\
\text { statistics and current }\end{array}$ \\
\hline
\end{tabular}




\begin{tabular}{|c|c|c|}
\hline & $\begin{array}{l}\text { quantitative } \\
\text { approach } \\
\text { appropriate? }\end{array}$ & $\begin{array}{l}\text { practices that the } \\
\text { mentioned hospital } \\
\text { performs. There was } \\
\text { a good match } \\
\text { between the } \\
\text { research problem } \\
\text { and the methods } \\
\text { used. A quantitative } \\
\text { approach was most } \\
\text { certainly } \\
\text { appropriate in this } \\
\text { study because they } \\
\text { were collecting data } \\
\text { on infection rates, } \\
\text { cost and } \\
\text { compliance. }\end{array}$ \\
\hline $\begin{array}{l}\text { Hypotheses or Research } \\
\text { Questions }\end{array}$ & $\begin{array}{l}\text { Were research } \\
\text { questions and/or } \\
\text { hypotheses explicitly } \\
\text { stated? If not, was } \\
\text { their absence } \\
\text { justified? } \\
\text { - Were questions and } \\
\text { hypotheses } \\
\text { appropriately } \\
\text { worded, with clear } \\
\text { specification of key } \\
\text { variables and the } \\
\text { study population? } \\
\text { Were the } \\
\text { questions/hypotheses } \\
\text { consistent with } \\
\text { existing knowledge? }\end{array}$ & $\begin{array}{l}\text { A research question } \\
\text { was not explicitly } \\
\text { stated but a } \\
\text { hypothesis was } \\
\text { explicitly stated at } \\
\text { the end of the } \\
\text { introduction section. } \\
\text { The hypothesis was } \\
\text { expertly and } \\
\text { appropriately } \\
\text { worded with very } \\
\text { clear and concise } \\
\text { specification of key } \\
\text { variables. Once } \\
\text { again, the study } \\
\text { population was only } \\
\text { broadly mentioned } \\
\text { as surgical patients, } \\
\text { but not specifically } \\
\text { which type of } \\
\text { surgical patients. } \\
\text { The hypothesis was } \\
\text { consistent with } \\
\text { existing knowledge. }\end{array}$ \\
\hline Literature Review & $\begin{array}{l}\text { Was the literature } \\
\text { review up-to-date } \\
\text { and based mainly on } \\
\text { primary sources? } \\
\text { Did the review } \\
\text { provide a state-of- }\end{array}$ & $\begin{array}{l}\text { Not all of the } \\
\text { literature was up to } \\
\text { date in the literature } \\
\text { review. Many of the } \\
\text { early cited articles } \\
\text { were from 2011- }\end{array}$ \\
\hline
\end{tabular}




\begin{tabular}{|c|c|c|}
\hline & $\begin{array}{l}\text { the-art synthesis of } \\
\text { evidence on the } \\
\text { problem? } \\
\text { - Did the literature } \\
\text { review provide a } \\
\text { strong basis for the } \\
\text { new study? }\end{array}$ & $\begin{array}{l}\text { 2013. As the } \\
\text { literature review } \\
\text { went on it started to } \\
\text { get specific about } \\
\text { the use of mupirocin } \\
\text { and the reduction of } \\
\text { surgical site } \\
\text { infections and some } \\
\text { of these references } \\
\text { dated back as far as } \\
\text { 1995. All sources } \\
\text { referenced were } \\
\text { primary sources. } \\
\text { The review was } \\
\text { fairly brief and } \\
\text { could have been } \\
\text { improved. Despite } \\
\text { this, the literature } \\
\text { review certainly } \\
\text { provided a strong } \\
\text { basis for the new } \\
\text { study. }\end{array}$ \\
\hline $\begin{array}{l}\text { Conceptual/Theoretical } \\
\text { Framework }\end{array}$ & $\begin{array}{l}\text { Were key concepts } \\
\text { adequately defined } \\
\text { conceptually? } \\
\text { - Was a } \\
\text { conceptual/theoretic } \\
\text { al framework } \\
\text { articulated-and, if } \\
\text { so, was it } \\
\text { appropriate? If not, } \\
\text { is the absence of a } \\
\text { framework justified? } \\
\text { Were the } \\
\text { questions/hypotheses } \\
\text { consistent with the } \\
\text { framework? }\end{array}$ & $\begin{array}{l}\text { Key concepts were } \\
\text { adequately defined } \\
\text { conceptually in this } \\
\text { study. There was no } \\
\text { conceptual/ } \\
\text { theoretical } \\
\text { framework utilized } \\
\text { in this study. The } \\
\text { absence of a } \\
\text { framework was } \\
\text { justified as this } \\
\text { quantitative study } \\
\text { had a nice flow and } \\
\text { was neatly } \\
\text { summarized in } \\
\text { various tables. }\end{array}$ \\
\hline $\begin{array}{l}\text { Method } \\
\text { Protection of Human Rights }\end{array}$ & $\begin{array}{l}\text { Were appropriate } \\
\text { procedures used to } \\
\text { safeguard the rights } \\
\text { of study } \\
\text { participants? } \\
\text { - Was the study } \\
\text { externally reviewed } \\
\text { by an IRB/ethics }\end{array}$ & $\begin{array}{l}\text { Appropriate } \\
\text { procedures were } \\
\text { used to safeguard } \\
\text { the rights of study } \\
\text { participants. The } \\
\text { study was reviewed } \\
\text { by the institutional } \\
\text { review board at }\end{array}$ \\
\hline
\end{tabular}




\begin{tabular}{|c|c|c|}
\hline & $\begin{array}{l}\text { review board? } \\
\text { Was the study } \\
\text { designed to } \\
\text { minimize risks and } \\
\text { maximize benefits to } \\
\text { participants? }\end{array}$ & $\begin{array}{l}\text { their institution and } \\
\text { informed consent } \\
\text { was obtained from } \\
\text { all study } \\
\text { participants. The } \\
\text { study was designed } \\
\text { to minimize risks } \\
\text { and maximize } \\
\text { benefits to } \\
\text { participants. } \\
\text { Patients received } \\
\text { verbal and written } \\
\text { instructions and had } \\
\text { access to a } 24 / 7 \\
\text { phone number in } \\
\text { case they had study } \\
\text { treatment related } \\
\text { questions. }\end{array}$ \\
\hline Research Design & $\begin{array}{l}\text { Was the most } \\
\text { rigorous design } \\
\text { used, given the study } \\
\text { purpose? } \\
\text { - Were appropriate } \\
\text { comparisons made to } \\
\text { enhance } \\
\text { interpretability of the } \\
\text { findings? } \\
\text { Was the number of } \\
\text { data collection } \\
\text { points appropriate? } \\
\text { Did the design } \\
\text { minimize biases and } \\
\text { threats to the } \\
\text { internal, construct, } \\
\text { and external validity } \\
\text { of the study (e.g., } \\
\text { was blinding used, } \\
\text { was attrition } \\
\text { minimized)? }\end{array}$ & $\begin{array}{l}\text { The research design } \\
\text { was an investigator } \\
\text { initiated, open label, } \\
\text { randomized trial } \\
\text { study. This was the } \\
\text { most rigorous } \\
\text { design that could } \\
\text { have been used. } \\
\text { Appropriate } \\
\text { comparisons were } \\
\text { made to enhance the } \\
\text { interpretability of } \\
\text { the findings. There } \\
\text { were three data } \\
\text { collection } \\
\text { outcomes: infection } \\
\text { rates; cost; and } \\
\text { patient compliance, } \\
\text { which were } \\
\text { appropriate for this } \\
\text { study. The design } \\
\text { did minimize biases } \\
\text { and threats to the } \\
\text { internal construct } \\
\text { and external validity } \\
\text { of the study by } \\
\text { being randomized to } \\
\text { either the mupirocin }\end{array}$ \\
\hline
\end{tabular}




\begin{tabular}{|c|c|c|}
\hline & & $\begin{array}{l}\text { or povidone iodine } \\
\text { treatment groups. } \\
\text { Patients were not } \\
\text { blinded to their } \\
\text { treatment group as } \\
\text { they were aware if } \\
\text { they were receiving } \\
\text { mupirocin or } \\
\text { povidone iodine. }\end{array}$ \\
\hline Population and Sample & $\begin{array}{l}\text { Was the population } \\
\text { identified? Was the } \\
\text { sample described in } \\
\text { sufficient detail? } \\
\text { - Was the best } \\
\text { possible sampling } \\
\text { design used to } \\
\text { enhance the } \\
\text { sample's } \\
\text { representativeness? } \\
\text { Were sampling } \\
\text { biases minimized? } \\
\text { Was the sample size } \\
\text { based on a power } \\
\text { analysis? }\end{array}$ & $\begin{array}{l}\text { The population was } \\
\text { identified in terms } \\
\text { of which type of } \\
\text { surgery they were } \\
\text { undergoing. There } \\
\text { was also a chart on } \\
\text { demographic } \\
\text { characteristics } \\
\text { describing the age, } \\
\text { sex, race, and } \\
\text { ethnicity of the } \\
\text { study participants. } \\
\text { The best possible } \\
\text { sampling design } \\
\text { was used to enhance } \\
\text { the sample's } \\
\text { representativeness. } \\
\text { Sampling biases } \\
\text { were minimized. In } \\
\text { the statistical } \\
\text { analysis section } \\
\text { there was mention } \\
\text { of the sample size } \\
\text { being based on a } \\
\text { power analysis; } \\
\text { however, this study } \\
\text { was unable to reach } \\
\text { the goal sample } \\
\text { size. }\end{array}$ \\
\hline $\begin{array}{l}\text { Data Collection and } \\
\text { Measurement }\end{array}$ & $\begin{array}{l}\text { Were the operational } \\
\text { and conceptual } \\
\text { definitions } \\
\text { congruent? } \\
\text { Were key variables } \\
\text { measured using an } \\
\text { appropriate method } \\
\text { (e.g., interviews, }\end{array}$ & $\begin{array}{l}\text { The operational and } \\
\text { conceptual } \\
\text { definitions were } \\
\text { congruent in this } \\
\text { study. The key } \\
\text { variables were } \\
\text { measured } \\
\text { appropriately using }\end{array}$ \\
\hline
\end{tabular}




\begin{tabular}{|c|c|c|}
\hline & $\begin{array}{l}\text { observations, and so } \\
\text { on)? } \\
\text { - Were specific } \\
\text { instruments } \\
\text { adequately described } \\
\text { and were they good } \\
\text { choices, given the } \\
\text { study population and } \\
\text { the variables being } \\
\text { studied? } \\
\text { Did the report } \\
\text { provide evidence } \\
\text { that the data } \\
\text { collection methods } \\
\text { yielded data that } \\
\text { were reliable, valid } \\
\text { and responsive? }\end{array}$ & $\begin{array}{l}\text { statistical analysis } \\
\text { for the quantitative } \\
\text { study. Specific } \\
\text { instruments were } \\
\text { adequately } \\
\text { described and were } \\
\text { good choices given } \\
\text { this study } \\
\text { population. } \\
\text { Categorical } \\
\text { variables were } \\
\text { analyzed using } \\
\text { Fisher's exact test. } \\
\text { The report provides } \\
\text { some evidence that } \\
\text { the date collection } \\
\text { methods yielded } \\
\text { data that was } \\
\text { reliable, valid, and } \\
\text { responsive by } \\
\text { utilizing } \\
\text { practitioners who } \\
\text { were blinded to } \\
\text { study participation } \\
\text { and receipt of study } \\
\text { treatment. Also, } \\
\text { microbiology } \\
\text { reports, hospital } \\
\text { readmissions and } \\
\text { reports from other } \\
\text { healthcare facilities } \\
\text { were used. }\end{array}$ \\
\hline Procedures & $\begin{array}{l}\text { If there was an } \\
\text { intervention, was it } \\
\text { adequately } \\
\text { described, and was it } \\
\text { rigorously developed } \\
\text { and implemented? } \\
\text { Did most } \\
\text { participants } \\
\text { allocated to the } \\
\text { intervention group } \\
\text { actually receive it? } \\
\text { Was there evidence } \\
\text { of intervention } \\
\text { fidelity? }\end{array}$ & $\begin{array}{l}\text { The intervention of } \\
\text { using mupirocin } \\
\text { versus povidone } \\
\text { iodine was certainly } \\
\text { adequately } \\
\text { described and was } \\
\text { rigorously } \\
\text { developed and } \\
\text { implemented. All } \\
\text { participants } \\
\text { allocated to the } \\
\text { intervention group } \\
\text { received either } \\
\text { mupirocin or }\end{array}$ \\
\hline
\end{tabular}




\begin{tabular}{|c|c|c|}
\hline & $\begin{array}{l}\text { Were data collected } \\
\text { in a manner that } \\
\text { minimized bias? } \\
\text { Were the staff who } \\
\text { collected data } \\
\text { appropriately } \\
\text { trained? }\end{array}$ & $\begin{array}{l}\text { povidone iodine. } \\
\text { There was no } \\
\text { evidence of } \\
\text { intervention fidelity } \\
\text { indicated. Date were } \\
\text { collected in a } \\
\text { manner that } \\
\text { minimized bias by } \\
\text { practitioners being } \\
\text { blinded to the study. } \\
\text { The staff appeared } \\
\text { to have been } \\
\text { adequately trained } \\
\text { on data collection as } \\
\text { they were from } \\
\text { Infection Prevention } \\
\text { and Control. }\end{array}$ \\
\hline Data Analysis & $\begin{array}{l}\text { Were analyses } \\
\text { undertaken to } \\
\text { address each } \\
\text { research question or } \\
\text { test each hypothesis? } \\
\text { - Were appropriate } \\
\text { statistical methods } \\
\text { used, given the level } \\
\text { of measurement of } \\
\text { the variables, } \\
\text { number of groups } \\
\text { being compared, and } \\
\text { assumptions of the } \\
\text { texts? } \\
\text { Was a powerful } \\
\text { analytic method } \\
\text { used? (e.g., did the } \\
\text { analysis help to } \\
\text { control for } \\
\text { confounding } \\
\text { variables)? } \\
\text { Were type I and } \\
\text { Type II errors } \\
\text { avoided or } \\
\text { minimized? } \\
\text { In intervention } \\
\text { studies, was an } \\
\text { intention-to-treat } \\
\text { analysis performed? }\end{array}$ & $\begin{array}{l}\text { There was no } \\
\text { mention of whether } \\
\text { analyses were } \\
\text { undertaken to } \\
\text { address each } \\
\text { research question or } \\
\text { test each hypothesis. } \\
\text { Statistical analysis } \\
\text { was conducted } \\
\text { using SAS version } \\
\text { 9.1. Categorical } \\
\text { variables were } \\
\text { analyzed using } \\
\text { Fisher's exact test. } \\
\text { These seem } \\
\text { appropriate } \\
\text { statistical methods } \\
\text { for this study. It is } \\
\text { not clear in this } \\
\text { study if the analysis } \\
\text { helped to control for } \\
\text { confounding } \\
\text { variables. Type I } \\
\text { and type II errors } \\
\text { were avoided. An } \\
\text { intention-to-treat } \\
\text { analysis was } \\
\text { performed. } \\
\text { Problems of missing }\end{array}$ \\
\hline
\end{tabular}




\begin{tabular}{|c|c|c|}
\hline & $\begin{array}{l}\text { Were problems of } \\
\text { missing values } \\
\text { evaluated and } \\
\text { adequately } \\
\text { addressed? }\end{array}$ & $\begin{array}{l}\text { values were } \\
\text { evaluated and } \\
\text { adequately } \\
\text { addressed. }\end{array}$ \\
\hline Findings & $\begin{array}{l}\text { Was information } \\
\text { about statistical } \\
\text { significance } \\
\text { presented? Was } \\
\text { information about } \\
\text { effect size and } \\
\text { precision of } \\
\text { estimates } \\
\text { (confidence } \\
\text { intervals) presented? } \\
\text { Were the findings } \\
\text { adequately } \\
\text { summarized, with } \\
\text { good use of tables } \\
\text { and figures? } \\
\text { Were findings } \\
\text { reported in a manner } \\
\text { that facilitates a } \\
\text { meta-analysis, and } \\
\text { with sufficient } \\
\text { information needed } \\
\text { for EBP? }\end{array}$ & $\begin{array}{l}\text { There was some } \\
\text { information about } \\
\text { statistical } \\
\text { significance } \\
\text { presented but there } \\
\text { were no confidence } \\
\text { intervals presented. } \\
\text { The findings were } \\
\text { adequately } \\
\text { summarized with } \\
\text { the use of multiple } \\
\text { tables and figures. } \\
\text { The findings were } \\
\text { reported in a } \\
\text { manner that } \\
\text { facilitated a meta- } \\
\text { analysis with } \\
\text { sufficient } \\
\text { information needed } \\
\text { for EBP. }\end{array}$ \\
\hline $\begin{array}{l}\text { Discussion } \\
\text { Interpretation of the Findings }\end{array}$ & $\begin{array}{l}\text { Were all major } \\
\text { findings interpreted } \\
\text { and discussed within } \\
\text { the context of prior } \\
\text { research and/or the } \\
\text { study's conceptual } \\
\text { framework? } \\
\text { - Were casual } \\
\text { inferences, if any, } \\
\text { justified? } \\
\text { Was the issue of } \\
\text { clinical significance } \\
\text { discussed? } \\
\text { Were interpretations } \\
\text { well-founded and } \\
\text { consistent with the } \\
\text { study's limitations? } \\
\text { Did the report } \\
\text { address the issue of }\end{array}$ & $\begin{array}{l}\text { All major findings } \\
\text { were interpreted and } \\
\text { discussed within the } \\
\text { context of prior } \\
\text { research. The issue } \\
\text { of clinical } \\
\text { significance was } \\
\text { discussed including } \\
\text { infection rates, cost, } \\
\text { and ease of use. } \\
\text { Interpretations were } \\
\text { well-founded and } \\
\text { consistent with the } \\
\text { study's limitations. } \\
\text { The report did } \\
\text { address the issue of } \\
\text { generalizability of } \\
\text { the findings given } \\
\text { this study was only }\end{array}$ \\
\hline
\end{tabular}




\begin{tabular}{|c|c|c|}
\hline & $\begin{array}{l}\text { the generalizability } \\
\text { of the findings? }\end{array}$ & $\begin{array}{l}\text { at one institution } \\
\text { and the results may } \\
\text { not be applicable to } \\
\text { other locations with } \\
\text { different patient } \\
\text { characteristics. }\end{array}$ \\
\hline Implications/Recommendations & $\begin{array}{l}\text { Did the researchers } \\
\text { discuss the } \\
\text { implications of the } \\
\text { study for clinical } \\
\text { practice or further } \\
\text { research-and were } \\
\text { those implications } \\
\text { reasonable and } \\
\text { complete? }\end{array}$ & $\begin{array}{l}\text { The researchers } \\
\text { briefly discussed the } \\
\text { implications of the } \\
\text { study for further } \\
\text { clinical practice } \\
\text { stating that } \\
\text { povidone iodine } \\
\text { may be considered } \\
\text { as an alternative to } \\
\text { mupirocin and a } \\
\text { component of a } \\
\text { multifaceted } \\
\text { approach to reduce } \\
\text { surgical site } \\
\text { infections. }\end{array}$ \\
\hline $\begin{array}{l}\text { General Issues } \\
\text { Presentation }\end{array}$ & $\begin{array}{l}\text { Was the report well- } \\
\text { written, organized, } \\
\text { and sufficiently } \\
\text { detailed for critical } \\
\text { analysis? } \\
\text { - In intervention } \\
\text { studies, was a } \\
\text { CONSORT } \\
\text { flowchart provided } \\
\text { to show the flow of } \\
\text { participants in the } \\
\text { study? } \\
\text { Was the report } \\
\text { written in a manner } \\
\text { that makes the } \\
\text { findings accessible } \\
\text { to practicing nurses? }\end{array}$ & $\begin{array}{l}\text { The report was well } \\
\text { written, organized, } \\
\text { and fairly } \\
\text { sufficiently detailed, } \\
\text { although there could } \\
\text { have been some } \\
\text { improvement in this } \\
\text { area. There was a } \\
\text { CONSORT } \\
\text { flowchart present to } \\
\text { show the flow of the } \\
\text { participants in the } \\
\text { study. This report } \\
\text { was written in a } \\
\text { manner that makes } \\
\text { the findings } \\
\text { accessible to } \\
\text { practicing nurses. }\end{array}$ \\
\hline Researcher Credibility & $\begin{array}{l}\text { Do the researchers' } \\
\text { clinical, substantive, } \\
\text { or methodologic } \\
\text { qualifications and } \\
\text { experience enhance } \\
\text { confidence in the } \\
\text { findings and their }\end{array}$ & $\begin{array}{l}\text { The researchers' } \\
\text { clinical } \\
\text { qualifications and } \\
\text { experience } \\
\text { enhanced } \\
\text { confidence in the } \\
\text { findings and their }\end{array}$ \\
\hline
\end{tabular}




\begin{tabular}{|c|c|c|}
\hline & interpretation? & interpretation. \\
\hline Summary Assessment & $\begin{array}{l}\text { Despite any } \\
\text { limitations, do the } \\
\text { study findings } \\
\text { appear to be valid- } \\
\text { do you have } \\
\text { confidence in the } \\
\text { truth value of the } \\
\text { results? } \\
\text { Does the study } \\
\text { contribute any } \\
\text { meaningful evidence } \\
\text { that can be used in } \\
\text { nursing practice or } \\
\text { that is useful to the } \\
\text { nursing discipline? }\end{array}$ & $\begin{array}{l}\text { While this was a } \\
\text { small study at only } \\
\text { one institution, there } \\
\text { is confidence in the } \\
\text { truth value of the } \\
\text { results. This study } \\
\text { definitely } \\
\text { contributed } \\
\text { meaningful } \\
\text { evidence that can be } \\
\text { used in nursing } \\
\text { practice and/or the } \\
\text { nursing discipline. } \\
\text { Especially since } \\
\text { povidone iodine } \\
\text { only has to be used } \\
\text { right before surgery, } \\
\text { it greatly increases } \\
\text { compliance and } \\
\text { reduces cost. }\end{array}$ \\
\hline
\end{tabular}




\section{Appendix A-2}

Anderson, M. J., David, M. L., Scholz, M., Bull, S. J., Morse, D., Hulse-Stevens, M., \& Peterson, M. L. (2015). Efficacy of skin and nasal povidone-iodine preparation against mupirocin-resistant methicillin-resistant staphylococcus aureus and S. aureus within the anterior nares. Antimicrobial Agents and Chemotherapy, 59(5), 2765-2773.

\begin{tabular}{|c|c|c|}
\hline Title & $\begin{array}{l}\text { Is the title a good } \\
\text { one, succinctly } \\
\text { suggesting key } \\
\text { variables and the } \\
\text { study population? }\end{array}$ & $\begin{array}{l}\text { The title was good in } \\
\text { terms of identifying } \\
\text { the key variables, } \\
\text { but it made no } \\
\text { mention of the study } \\
\text { population. }\end{array}$ \\
\hline Abstract & $\begin{array}{l}\text { Did the abstract } \\
\text { clearly and } \\
\text { concisely } \\
\text { summarize the } \\
\text { main features of the } \\
\text { report (problem, } \\
\text { methods, results, } \\
\text { conclusions)? }\end{array}$ & $\begin{array}{l}\text { The abstract was } \\
\text { great as it clearly } \\
\text { and concisely } \\
\text { summarized the } \\
\text { main features of the } \\
\text { report. }\end{array}$ \\
\hline $\begin{array}{l}\text { Introduction } \\
\text { Statement of the Problem }\end{array}$ & $\begin{array}{l}\text { Was the problem } \\
\text { stated } \\
\text { unambiguously, } \\
\text { and was it easy to } \\
\text { identify? } \\
\text { - Is the problem } \\
\text { statement build a } \\
\text { persuasive } \\
\text { argument for the } \\
\text { new study? } \\
\text { Was there a good } \\
\text { match between the } \\
\text { research problem } \\
\text { and the methods } \\
\text { used -that is, was a } \\
\text { quantitative } \\
\text { approach } \\
\text { appropriate? }\end{array}$ & $\begin{array}{l}\text { The problem was } \\
\text { stated } \\
\text { unambiguously and } \\
\text { was very easy to } \\
\text { identify and built a } \\
\text { persuasive argument } \\
\text { for a new study. } \\
\text { There was a good } \\
\text { match between the } \\
\text { research problem } \\
\text { and the methods as a } \\
\text { quantitative study } \\
\text { was appropriate in } \\
\text { this situation to } \\
\text { collect numerical } \\
\text { data. }\end{array}$ \\
\hline $\begin{array}{l}\text { Hypotheses or Research } \\
\text { Questions }\end{array}$ & $\begin{array}{l}\text { Were research } \\
\text { questions and/or } \\
\text { hypotheses } \\
\text { explicitly stated? If } \\
\text { not, was their } \\
\text { absence justified? }\end{array}$ & $\begin{array}{l}\text { The hypotheses were } \\
\text { explicitly stated at } \\
\text { the end of the } \\
\text { introduction section } \\
\text { and were clearly } \\
\text { worded with }\end{array}$ \\
\hline
\end{tabular}




\begin{tabular}{|c|c|c|}
\hline & $\begin{array}{l}\text { - Were questions and } \\
\text { hypotheses } \\
\text { appropriately } \\
\text { worded, with clear } \\
\text { specification of key } \\
\text { variables and the } \\
\text { study population? } \\
\text { - Were the } \\
\text { questions/hypothes } \\
\text { es consistent with } \\
\text { existing } \\
\text { knowledge? }\end{array}$ & $\begin{array}{l}\text { specification to key } \\
\text { variables and the } \\
\text { study population. } \\
\text { The hypotheses were } \\
\text { backed up with } \\
\text { existing knowledge } \\
\text { throughout the } \\
\text { introduction section. }\end{array}$ \\
\hline Literature Review & $\begin{array}{l}\text { Was the literature } \\
\text { review up-to-date } \\
\text { and based mainly } \\
\text { on primary } \\
\text { sources? } \\
\text { Did the review } \\
\text { provide a state-of- } \\
\text { the-art synthesis of } \\
\text { evidence on the } \\
\text { problem? } \\
\text { Did the literature } \\
\text { review provide a } \\
\text { strong basis for the } \\
\text { new study? }\end{array}$ & $\begin{array}{l}\text { While a majority of } \\
\text { the literature review } \\
\text { was from the past } \\
\text { ten years, there were } \\
\text { some that dated as } \\
\text { far back as twenty } \\
\text { years. They were all } \\
\text { primary sources. } \\
\text { The literature review } \\
\text { provided a state-of } \\
\text { the art synthesis of } \\
\text { the evidence on the } \\
\text { problem and } \\
\text { certainly provided a } \\
\text { strong basis for the } \\
\text { new study. }\end{array}$ \\
\hline $\begin{array}{l}\text { Conceptual/Theoretical } \\
\text { Framework }\end{array}$ & $\begin{array}{l}\text { - Were key concepts } \\
\text { adequately defined } \\
\text { conceptually? } \\
\text { Was a } \\
\text { conceptual/theoreti } \\
\text { cal framework } \\
\text { articulated-and, if } \\
\text { so, was it } \\
\text { appropriate? If not, } \\
\text { is the absence of a } \\
\text { framework } \\
\text { justified? } \\
\text { Were the } \\
\text { questions/hypothes } \\
\text { es consistent with } \\
\text { the framework? }\end{array}$ & $\begin{array}{l}\text { There was no } \\
\text { conceptual/theoretic } \\
\text { al framework } \\
\text { articulated and its' } \\
\text { absence was not } \\
\text { addressed but the } \\
\text { study was well } \\
\text { articulated and had a } \\
\text { good flow without it. }\end{array}$ \\
\hline $\begin{array}{l}\text { Method } \\
\text { Protection of Human Rights }\end{array}$ & $\begin{array}{l}\text { Were appropriate } \\
\text { procedures used to }\end{array}$ & $\begin{array}{l}\text { There was very little } \\
\text { information }\end{array}$ \\
\hline
\end{tabular}




\begin{tabular}{|c|c|c|}
\hline & $\begin{array}{l}\text { safe-guard the } \\
\text { rights of study } \\
\text { participants? } \\
\text { - Was the study } \\
\text { externally reviewed } \\
\text { by an IRB/ethics } \\
\text { review board? } \\
\text { - Was the study } \\
\text { designed to } \\
\text { minimize risks and } \\
\text { maximize benefits } \\
\text { to participants? }\end{array}$ & $\begin{array}{l}\text { regarding } \\
\text { appropriate } \\
\text { procedures used to } \\
\text { safeguard the rights } \\
\text { of study participants. } \\
\text { It was noted in the } \\
\text { section regarding } \\
\text { human skin explants } \\
\text { that IRB review was } \\
\text { not needed but under } \\
\text { the human subjects' } \\
\text { section there was no } \\
\text { mention of an IRB } \\
\text { review. While there } \\
\text { was no mention of } \\
\text { the study being } \\
\text { designed to } \\
\text { minimize risks and } \\
\text { maximize benefits to } \\
\text { participants, this } \\
\text { study did involve } \\
\text { minimal risk to } \\
\text { study participants. }\end{array}$ \\
\hline Research Design & $\begin{array}{l}\text { Was the most } \\
\text { rigorous design } \\
\text { used, given the } \\
\text { study purpose? } \\
\text { Were appropriate } \\
\text { comparisons made } \\
\text { to enhance } \\
\text { interpretability of } \\
\text { the findings? } \\
\text { Was the number of } \\
\text { data collection } \\
\text { points appropriate? } \\
\text { Did the design } \\
\text { minimize biases } \\
\text { and threats to the } \\
\text { internal, construct, } \\
\text { and external } \\
\text { validity of the study } \\
\text { (e.g., was blinding } \\
\text { used, was attrition } \\
\text { minimized)? }\end{array}$ & $\begin{array}{l}\text { While this was } \\
\text { clearly a quantitative } \\
\text { study, there was no } \\
\text { mention of which } \\
\text { type of study this } \\
\text { was. The authors } \\
\text { simply referred to it } \\
\text { as an analysis. This } \\
\text { was appropriate as } \\
\text { this was a very } \\
\text { structured and } \\
\text { organized study. } \\
\text { There were five data } \\
\text { collection points } \\
\text { which was } \\
\text { appropriate as there } \\
\text { were five different } \\
\text { interventions in this } \\
\text { study. Threats to the } \\
\text { internal construct } \\
\text { and external validity } \\
\text { of the study were } \\
\text { minimized. In terms }\end{array}$ \\
\hline
\end{tabular}




\begin{tabular}{|c|c|c|}
\hline & & $\begin{array}{l}\text { of the human } \\
\text { subjects, there was } \\
\text { no mention of } \\
\text { whether the design } \\
\text { minimized biases } \\
\text { and threats to } \\
\text { external } \\
\text { constructs/external } \\
\text { validity. }\end{array}$ \\
\hline Population and Sample & $\begin{array}{l}\text { - Was the population } \\
\text { identified? Was the } \\
\text { sample described in } \\
\text { sufficient detail? } \\
\text { - Was the best } \\
\text { possible sampling } \\
\text { design used to } \\
\text { enhance the } \\
\text { sample's } \\
\text { representativeness? } \\
\text { Were sampling } \\
\text { biases minimized? } \\
\text { Was the sample } \\
\text { size based on a } \\
\text { power analysis? }\end{array}$ & $\begin{array}{l}\text { While there were } \\
\text { explicit details } \\
\text { regarding bacterial } \\
\text { growth and } \\
\text { inoculation, ex vivo } \\
\text { porcine vaginal } \\
\text { mucosa, } \\
\text { procurement culture } \\
\text { of human skin } \\
\text { explants, application } \\
\text { of test formulations } \\
\text { or comparators, } \\
\text { mucin wash, and } \\
\text { bacterial } \\
\text { enumeration, the } \\
\text { population of human } \\
\text { subjects was not } \\
\text { identified. Due to } \\
\text { the lack of } \\
\text { information, it was } \\
\text { hard to determine if } \\
\text { the best possible } \\
\text { sampling design was } \\
\text { used. There was no } \\
\text { mention of a power } \\
\text { analysis being used. }\end{array}$ \\
\hline $\begin{array}{l}\text { Data Collection and } \\
\text { Measurement }\end{array}$ & $\begin{array}{l}\text { - Were the } \\
\text { operational and } \\
\text { conceptual } \\
\text { definitions } \\
\text { congruent? } \\
\text { - Were key variables } \\
\text { measured using an } \\
\text { appropriate method } \\
\text { (e.g., interviews, } \\
\text { observations, and } \\
\text { so on)? }\end{array}$ & $\begin{array}{l}\text { The operational and } \\
\text { conceptual } \\
\text { definitions were } \\
\text { congruent. Key } \\
\text { variables were } \\
\text { measured } \\
\text { appropriately using } \\
\text { observations and } \\
\text { data collection. } \\
\text { Specific instruments } \\
\text { were briefly }\end{array}$ \\
\hline
\end{tabular}




\begin{tabular}{|c|c|c|}
\hline & $\begin{array}{l}\text { Were specific } \\
\text { instruments } \\
\text { adequately } \\
\text { described and were } \\
\text { they good choices, } \\
\text { given the study } \\
\text { population and the } \\
\text { variables being } \\
\text { studied? } \\
\text { Did the report } \\
\text { provide evidence } \\
\text { that the data } \\
\text { collection methods } \\
\text { yielded data that } \\
\text { were reliable, valid } \\
\text { and responsive? }\end{array}$ & $\begin{array}{l}\text { mentioned and } \\
\text { seemed to be good } \\
\text { choices given the } \\
\text { study population. } \\
\text { The report provided } \\
\text { evidence that the } \\
\text { data collection } \\
\text { methods yielded } \\
\text { data that were } \\
\text { reliable, valid, and } \\
\text { responsive. }\end{array}$ \\
\hline Procedures & $\begin{array}{l}\text { If there was an } \\
\text { intervention, was it } \\
\text { adequately } \\
\text { described, and was } \\
\text { it rigorously } \\
\text { developed and } \\
\text { implemented? Did } \\
\text { most participants } \\
\text { allocated to the } \\
\text { intervention group } \\
\text { actually receive it? } \\
\text { Was there evidence } \\
\text { of intervention } \\
\text { fidelity? } \\
\text { Were data collected } \\
\text { in a manner that } \\
\text { minimized bias? } \\
\text { Were the staff who } \\
\text { collected data } \\
\text { appropriately } \\
\text { trained? }\end{array}$ & $\begin{array}{l}\text { There were several } \\
\text { different } \\
\text { interventions in this } \\
\text { study and they were } \\
\text { all very rigorously } \\
\text { developed and } \\
\text { implemented. There } \\
\text { was a very detailed } \\
\text { description of all } \\
\text { interventions. Data } \\
\text { were collected in a } \\
\text { manner that } \\
\text { minimized bias and } \\
\text { there was mention of } \\
\text { staff being } \\
\text { appropriately } \\
\text { trained. }\end{array}$ \\
\hline Data Analysis & $\begin{array}{l}\text { Were analyses } \\
\text { undertaken to } \\
\text { address each } \\
\text { research question or } \\
\text { test each } \\
\text { hypothesis? } \\
\text { - Were appropriate } \\
\text { statistical methods } \\
\text { used, given the }\end{array}$ & $\begin{array}{l}\text { Statistical analyses } \\
\text { were undertaken to } \\
\text { address each } \\
\text { hypothesis. The } \\
\text { appropriate } \\
\text { statistical methods } \\
\text { were used in this } \\
\text { study and included } \\
\text { analysis of variance }\end{array}$ \\
\hline
\end{tabular}




\begin{tabular}{|c|c|c|}
\hline & $\begin{array}{l}\text { level of } \\
\text { measurement of the } \\
\text { variables, number } \\
\text { of groups being } \\
\text { compared, and } \\
\text { assumptions of the } \\
\text { texts? } \\
\text { - Was a powerful } \\
\text { analytic method } \\
\text { used? (e.g., did the } \\
\text { analysis help to } \\
\text { control for } \\
\text { confounding } \\
\text { variables)? } \\
\text { - Were type I and } \\
\text { Type II errors } \\
\text { avoided or } \\
\text { minimized? } \\
\text { - In intervention } \\
\text { studies, was an } \\
\text { intention-to-treat } \\
\text { analysis performed? } \\
\text { Were problems of } \\
\text { missing values } \\
\text { evaluated and } \\
\text { adequately } \\
\text { addressed? }\end{array}$ & $\begin{array}{l}\text { followed by } \\
\text { Bonferroni's posttest } \\
\text { using the GraphPad } \\
\text { PRISM software. } \\
\text { The student's t test } \\
\text { was used to evaluate } \\
\text { significant } \\
\text { differences at each } \\
\text { time point. There } \\
\text { was no mention of } \\
\text { whether an } \\
\text { intention-to-treat } \\
\text { analysis was } \\
\text { performed. There } \\
\text { were no missing } \\
\text { values noted. }\end{array}$ \\
\hline Findings & $\begin{array}{l}\text { Was information } \\
\text { about statistical } \\
\text { significance } \\
\text { presented? Was } \\
\text { information about } \\
\text { effect size and } \\
\text { precision of } \\
\text { estimates } \\
\text { (confidence } \\
\text { intervals) } \\
\text { presented? } \\
\text { - Were the findings } \\
\text { adequately } \\
\text { summarized, with } \\
\text { good use of tables } \\
\text { and figures? } \\
\text { - Were findings } \\
\text { reported in a } \\
\text { manner that }\end{array}$ & $\begin{array}{l}\text { Statistical } \\
\text { significance was } \\
\text { presented but there } \\
\text { was no information } \\
\text { about effect size and } \\
\text { precision of } \\
\text { estimates presented. } \\
\text { There were some } \\
\text { tables presented } \\
\text { which adequately } \\
\text { summarized the } \\
\text { information. The } \\
\text { findings were } \\
\text { reported in a manner } \\
\text { that facilitated a } \\
\text { meta-analysis and } \\
\text { with sufficient } \\
\text { information needed } \\
\text { for EBP. }\end{array}$ \\
\hline
\end{tabular}




\begin{tabular}{|c|c|c|}
\hline & $\begin{array}{l}\text { facilitates a meta- } \\
\text { analysis, and with } \\
\text { sufficient } \\
\text { information needed } \\
\text { for EBP? }\end{array}$ & \\
\hline $\begin{array}{l}\text { Discussion } \\
\text { Interpretation of the Findings }\end{array}$ & $\begin{array}{l}\text { Were all major } \\
\text { findings interpreted } \\
\text { and discussed } \\
\text { within the context } \\
\text { of prior research } \\
\text { and/or the study's } \\
\text { conceptual } \\
\text { framework? } \\
\text { - Were casual } \\
\text { inferences, if any, } \\
\text { justified? } \\
\text { Was the issue of } \\
\text { clinical significance } \\
\text { discussed? } \\
\text { Were } \\
\text { interpretations well- } \\
\text { founded and } \\
\text { consistent with the } \\
\text { study's limitations? } \\
\text { Did the report } \\
\text { address the issue of } \\
\text { the generalizability } \\
\text { of the findings? }\end{array}$ & $\begin{array}{l}\text { The authors did a } \\
\text { great job of } \\
\text { discussing the } \\
\text { findings within } \\
\text { context of prior } \\
\text { research. Casual } \\
\text { inferences were } \\
\text { justified. The issue } \\
\text { of clinical } \\
\text { significance was } \\
\text { certainly discussed. } \\
\text { Interpretations were } \\
\text { well-founded and } \\
\text { consistent with the } \\
\text { study's limitations. } \\
\text { There was no } \\
\text { mention of the issue } \\
\text { of the } \\
\text { generalizability of } \\
\text { the findings. }\end{array}$ \\
\hline Implications/Recommendations & $\begin{array}{l}\text { Did the researchers } \\
\text { discuss the } \\
\text { implications of the } \\
\text { study for clinical } \\
\text { practice or further } \\
\text { research-and were } \\
\text { those implications } \\
\text { reasonable and } \\
\text { complete? }\end{array}$ & $\begin{array}{l}\text { The researchers did } \\
\text { discuss the } \\
\text { implications of the } \\
\text { study for clinical } \\
\text { practice and } \\
\text { suggested that the } \\
\text { use of povidone- } \\
\text { iodine should be } \\
\text { considered as an } \\
\text { alternative for } \\
\text { reducing the } \\
\text { bioburden of } \\
\text { anterior nares prior } \\
\text { to surgery. }\end{array}$ \\
\hline $\begin{array}{l}\text { General Issues } \\
\text { Presentation }\end{array}$ & $\begin{array}{l}\text { Was the report } \\
\text { well-written, } \\
\text { organized, and } \\
\text { sufficiently detailed }\end{array}$ & $\begin{array}{l}\text { The report was well- } \\
\text { written, organized, } \\
\text { and sufficiently } \\
\text { detailed for critical }\end{array}$ \\
\hline
\end{tabular}




\begin{tabular}{|c|c|c|}
\hline & $\begin{array}{l}\text { for critical } \\
\text { analysis? } \\
\text { - In intervention } \\
\text { studies, was a } \\
\text { CONSORT } \\
\text { flowchart provided } \\
\text { to show the flow of } \\
\text { participants in the } \\
\text { study? } \\
\text { Was the report } \\
\text { written in a manner } \\
\text { that makes the } \\
\text { findings accessible } \\
\text { to practicing } \\
\text { nurses? }\end{array}$ & $\begin{array}{l}\text { analysis. There was } \\
\text { no CONSORT } \\
\text { flowchart provided. } \\
\text { The report was } \\
\text { certainly written in a } \\
\text { manner that makes } \\
\text { the findings } \\
\text { accessible to } \\
\text { practicing nurses. }\end{array}$ \\
\hline Researcher Credibility & $\begin{array}{l}\text { Do the researchers' } \\
\text { clinical, } \\
\text { substantive, or } \\
\text { methodologic } \\
\text { qualifications and } \\
\text { experience enhance } \\
\text { confidence in the } \\
\text { findings and their } \\
\text { interpretation? }\end{array}$ & $\begin{array}{l}\text { The credentials of } \\
\text { the researchers were } \\
\text { not noted but they } \\
\text { belonged to the } \\
\text { department of } \\
\text { experimental and } \\
\text { clinical } \\
\text { pharmacology and } \\
\text { were part of the } 3 \mathrm{M} \\
\text { infection prevention } \\
\text { division. They had } \\
\text { experience in this } \\
\text { field. }\end{array}$ \\
\hline Summary Assessment & $\begin{array}{l}\text { Despite any } \\
\text { limitations, do the } \\
\text { study findings } \\
\text { appear to be } \\
\text { valid-do you have } \\
\text { confidence in the } \\
\text { truth value of the } \\
\text { results? } \\
\text { Does the study } \\
\text { contribute any } \\
\text { meaningful } \\
\text { evidence that can } \\
\text { be used in nursing } \\
\text { practice or that is } \\
\text { useful to the } \\
\text { nursing discipline? }\end{array}$ & $\begin{array}{l}\text { While the human } \\
\text { portion of this study } \\
\text { had a small sample } \\
\text { size, there were also } \\
\text { explant models } \\
\text { which were } \\
\text { inoculated in a } \\
\text { controlled } \\
\text { environment; } \\
\text { therefore, the } \\
\text { findings appeared to } \\
\text { be valid. This study } \\
\text { certainly contributed } \\
\text { meaningful evidence } \\
\text { that can be used in } \\
\text { nursing practice, } \\
\text { further supporting } \\
\text { that the use of }\end{array}$ \\
\hline
\end{tabular}




\begin{tabular}{|l|l|}
\hline & $\begin{array}{l}\text { povidone-iodine } \\
\text { may be an } \\
\text { alternative for } \\
\text { reducing the } \\
\text { bioburden of } \\
\text { anterior nares prior } \\
\text { to surgery. }\end{array}$ \\
\hline
\end{tabular}




\section{Appendix A-3}

Bebko, S. P., Green, D. M., \& Awad, S. S. (2015). Effect of a preoperative decontamination protocol on surgical site infections in patients undergoing elective orthopedic surgery with hardware implantation. JAMA Surgery, 150(5), 390-395.

\begin{tabular}{|c|c|c|}
\hline Title & $\begin{array}{l}\text { Is the title a good } \\
\text { one, succinctly } \\
\text { suggesting key } \\
\text { variables and the } \\
\text { study population? }\end{array}$ & $\begin{array}{l}\text { The title did a good } \\
\text { job of succinctly } \\
\text { suggesting key } \\
\text { variables and the } \\
\text { study population. }\end{array}$ \\
\hline Abstract & $\begin{array}{l}\text { Did the abstract } \\
\text { clearly and concisely } \\
\text { summarize the main } \\
\text { features of the report } \\
\text { (problem, methods, } \\
\text { results, } \\
\text { conclusions)? }\end{array}$ & $\begin{array}{l}\text { The abstract } \\
\text { summarized the } \\
\text { main features of the } \\
\text { report. There were } \\
\text { separate sections for } \\
\text { importance, } \\
\text { objective, design, } \\
\text { setting, participants, } \\
\text { interventions, } \\
\text { outcomes, measures, } \\
\text { results, and } \\
\text { conclusions. }\end{array}$ \\
\hline $\begin{array}{l}\text { Introduction } \\
\text { Statement of the Problem }\end{array}$ & $\begin{array}{l}\text { Was the problem } \\
\text { stated } \\
\text { unambiguously, and } \\
\text { was it easy to } \\
\text { identify? } \\
\text { Is the problem } \\
\text { statement build a } \\
\text { persuasive argument } \\
\text { for the new study? } \\
\text { Was there a good } \\
\text { match between the } \\
\text { research problem } \\
\text { and the methods } \\
\text { used -that is, was a } \\
\text { quantitative } \\
\text { approach } \\
\text { appropriate? }\end{array}$ & $\begin{array}{l}\text { In the introduction, } \\
\text { the problem was } \\
\text { stated } \\
\text { unambiguously, and } \\
\text { it was easy to } \\
\text { identify. The } \\
\text { problem statement } \\
\text { did build a } \\
\text { persuasive argument } \\
\text { for the new study, } \\
\text { citing the high cost } \\
\text { and prevalence of } \\
\text { surgical site } \\
\text { infections. There was } \\
\text { a good match } \\
\text { between the research } \\
\text { problem and the } \\
\text { methods used and a } \\
\text { quantitative study } \\
\text { was appropriate. }\end{array}$ \\
\hline $\begin{array}{l}\text { Hypotheses or Research } \\
\text { Questions }\end{array}$ & $\begin{array}{ll}\text { - } & \text { Were research } \\
\text { questions and/or } \\
\text { hypotheses explicitly }\end{array}$ & $\begin{array}{l}\text { The research } \\
\text { question was } \\
\text { explicitly stated. The }\end{array}$ \\
\hline
\end{tabular}




\begin{tabular}{|c|c|c|}
\hline & $\begin{array}{l}\text { stated? If not, was } \\
\text { their absence } \\
\text { justified? } \\
\text { - Were questions and } \\
\text { hypotheses } \\
\text { appropriately } \\
\text { worded, with clear } \\
\text { specification of key } \\
\text { variables and the } \\
\text { study population? } \\
\text { Were the } \\
\text { questions/hypotheses } \\
\text { consistent with } \\
\text { existing knowledge? }\end{array}$ & $\begin{array}{l}\text { research question } \\
\text { was appropriately } \\
\text { worded with clear } \\
\text { specification of key } \\
\text { variables and the } \\
\text { study population. } \\
\text { The research } \\
\text { question was } \\
\text { consistent with } \\
\text { existing knowledge. }\end{array}$ \\
\hline Literature Review & $\begin{array}{l}\text { Was the literature } \\
\text { review up-to-date } \\
\text { and based mainly on } \\
\text { primary sources? } \\
\text { Did the review } \\
\text { provide a state-of- } \\
\text { the-art synthesis of } \\
\text { evidence on the } \\
\text { problem? } \\
\text { Did the literature } \\
\text { review provide a } \\
\text { strong basis for the } \\
\text { new study? }\end{array}$ & $\begin{array}{l}\text { The literature review } \\
\text { consisted of primary } \\
\text { sources dating back } \\
\text { to the early 2000s. } \\
\text { The review provided } \\
\text { a state-of-the-art } \\
\text { synthesis of evidence } \\
\text { on the problem. The } \\
\text { literature review } \\
\text { provided a strong } \\
\text { basis for the new } \\
\text { study. }\end{array}$ \\
\hline $\begin{array}{l}\text { Conceptual/Theoretical } \\
\text { Framework }\end{array}$ & $\begin{array}{l}\text { Were key concepts } \\
\text { adequately defined } \\
\text { conceptually? } \\
\text { Was a } \\
\text { conceptual/theoretic } \\
\text { al framework } \\
\text { articulated-and, if } \\
\text { so, was it } \\
\text { appropriate? If not, } \\
\text { is the absence of a } \\
\text { framework justified? } \\
\text { Were the } \\
\text { questions/hypotheses } \\
\text { consistent with the } \\
\text { framework? }\end{array}$ & $\begin{array}{l}\text { The key concepts } \\
\text { were adequately } \\
\text { defined } \\
\text { conceptually. There } \\
\text { was no theoretical } \\
\text { conceptual } \\
\text { framework } \\
\text { articulated. Its' } \\
\text { absence is not } \\
\text { justified in the study. } \\
\text { The research } \\
\text { question was } \\
\text { consistent with the } \\
\text { framework. }\end{array}$ \\
\hline $\begin{array}{l}\text { Method } \\
\text { Protection of Human Rights }\end{array}$ & $\begin{array}{l}\text { Were appropriate } \\
\text { procedures used to } \\
\text { safe-guard the rights } \\
\text { of study }\end{array}$ & $\begin{array}{l}\text { Appropriate } \\
\text { procedures were } \\
\text { used to safeguard the } \\
\text { rights of the study }\end{array}$ \\
\hline
\end{tabular}




\begin{tabular}{|c|c|c|}
\hline & $\begin{array}{l}\text { participants? } \\
\text { Was the study } \\
\text { externally reviewed } \\
\text { by an IRB/ethics } \\
\text { review board? } \\
\text { - Was the study } \\
\text { designed to } \\
\text { minimize risks and } \\
\text { maximize benefits to } \\
\text { participants? }\end{array}$ & $\begin{array}{l}\text { participants. The } \\
\text { study was approved } \\
\text { by the institutional } \\
\text { review board at the } \\
\text { Michael E. DeBakey } \\
\text { Veterans Affairs } \\
\text { Medical Center. As } \\
\text { this was a } \\
\text { retrospective review } \\
\text { of de-identified data, } \\
\text { oral or written } \\
\text { informed consent } \\
\text { was waived. This } \\
\text { study was designed } \\
\text { to minimize the risks } \\
\text { and maximize the } \\
\text { benefits to } \\
\text { participants. }\end{array}$ \\
\hline Research Design & $\begin{array}{l}\text { Was the most } \\
\text { rigorous design } \\
\text { used, given the study } \\
\text { purpose? } \\
\text { Were appropriate } \\
\text { comparisons made to } \\
\text { enhance } \\
\text { interpretability of the } \\
\text { findings? } \\
\text { Was the number of } \\
\text { data collection } \\
\text { points appropriate? } \\
\text { Did the design } \\
\text { minimize biases and } \\
\text { threats to the } \\
\text { internal, construct, } \\
\text { and external validity } \\
\text { of the study (e.g., } \\
\text { was blinding used, } \\
\text { was attrition } \\
\text { minimized)? }\end{array}$ & $\begin{array}{l}\text { The study used a } \\
\text { quantitative design } \\
\text { and this was } \\
\text { appropriate given the } \\
\text { study purpose. The } \\
\text { study was described } \\
\text { as a prospective } \\
\text { clinical study. } \\
\text { Appropriate } \\
\text { comparisons were } \\
\text { made to enhance } \\
\text { interpretability of the } \\
\text { findings. The } \\
\text { number of data } \\
\text { collection points was } \\
\text { appropriate. The } \\
\text { design minimized } \\
\text { biases and threats to } \\
\text { the internal, } \\
\text { construct, and } \\
\text { external validity of } \\
\text { the study. }\end{array}$ \\
\hline Population and Sample & $\begin{array}{l}\text { Was the population } \\
\text { identified? Was the } \\
\text { sample described in } \\
\text { sufficient detail? } \\
\text { - Was the best } \\
\text { possible sampling }\end{array}$ & $\begin{array}{l}\text { The population was } \\
\text { identified as patients } \\
\text { undergoing elective } \\
\text { orthopedic surgery } \\
\text { with hardware } \\
\text { implantation }\end{array}$ \\
\hline
\end{tabular}




\begin{tabular}{|c|c|c|}
\hline & $\begin{array}{l}\text { design used to } \\
\text { enhance the } \\
\text { sample's } \\
\text { representativeness? } \\
\text { Were sampling } \\
\text { biases minimized? } \\
\text { - Was the sample size } \\
\text { based on a power } \\
\text { analysis? }\end{array}$ & $\begin{array}{l}\text { between October } 1 \text {, } \\
2012 \text { through } \\
\text { December } 31,2013 \text {. } \\
\text { The best possible } \\
\text { sampling design was } \\
\text { used to enhance the } \\
\text { sample's } \\
\text { representativeness } \\
\text { and sampling biases } \\
\text { were minimized. } \\
\text { There was no } \\
\text { mention of a power } \\
\text { analysis being used } \\
\text { to determine the } \\
\text { sample size. All } \\
\text { patients that met the } \\
\text { criteria during the } \\
\text { specified period of } \\
\text { time were utilized. }\end{array}$ \\
\hline $\begin{array}{l}\text { Data Collection and } \\
\text { Measurement }\end{array}$ & $\begin{array}{l}\text { Were the operational } \\
\text { and conceptual } \\
\text { definitions } \\
\text { congruent? } \\
\text { Were key variables } \\
\text { measured using an } \\
\text { appropriate method } \\
\text { (e.g., interviews, } \\
\text { observations, and so } \\
\text { on)? } \\
\text { Were specific } \\
\text { instruments } \\
\text { adequately described } \\
\text { and were they good } \\
\text { choices, given the } \\
\text { study population and } \\
\text { the variables being } \\
\text { studied? } \\
\text { Did the report } \\
\text { provide evidence } \\
\text { that the data } \\
\text { collection methods } \\
\text { yielded data that } \\
\text { were reliable, valid } \\
\text { and responsive? }\end{array}$ & $\begin{array}{l}\text { The operational and } \\
\text { conceptual } \\
\text { definitions were } \\
\text { congruent. Key } \\
\text { variables were } \\
\text { measured } \\
\text { appropriately using } \\
\text { descriptive statistics } \\
\text { for data collection } \\
\text { and statistical } \\
\text { analysis. The } \\
\text { instruments were } \\
\text { adequately described } \\
\text { and were good } \\
\text { choices given the } \\
\text { study population and } \\
\text { the variables being } \\
\text { studied. The report } \\
\text { did provide evidence } \\
\text { that the data } \\
\text { collection methods } \\
\text { yielded data that } \\
\text { were reliable, valid, } \\
\text { and responsive. }\end{array}$ \\
\hline Procedures & $\begin{array}{l}\text { - If there was an } \\
\text { intervention, was it }\end{array}$ & $\begin{array}{l}\text { There was an } \\
\text { intervention and it }\end{array}$ \\
\hline
\end{tabular}




\begin{tabular}{|c|c|c|}
\hline & $\begin{array}{l}\text { adequately } \\
\text { described, and was it } \\
\text { rigorously developed } \\
\text { and implemented? } \\
\text { Did most } \\
\text { participants } \\
\text { allocated to the } \\
\text { intervention group } \\
\text { actually receive it? } \\
\text { Was there evidence } \\
\text { of intervention } \\
\text { fidelity? } \\
\text { Were data collected } \\
\text { in a manner that } \\
\text { minimized bias? } \\
\text { Were the staff who } \\
\text { collected data } \\
\text { appropriately } \\
\text { trained? }\end{array}$ & $\begin{array}{l}\text { was adequately } \\
\text { described, rigorously } \\
\text { developed, and } \\
\text { implemented. All } \\
\text { participants allocated } \\
\text { to the intervention } \\
\text { group actually } \\
\text { received it. There } \\
\text { was evidence of } \\
\text { intervention fidelity. } \\
\text { The researchers were } \\
\text { blinded to patient } \\
\text { identifiers; therefore } \\
\text { bias was minimized. } \\
\text { The staff who } \\
\text { collected the data } \\
\text { were appropriately } \\
\text { trained. }\end{array}$ \\
\hline Data Analysis & $\begin{array}{l}\text { Were analyses } \\
\text { undertaken to } \\
\text { address each } \\
\text { research question or } \\
\text { test each hypothesis? } \\
\text { Were appropriate } \\
\text { statistical methods } \\
\text { used, given the level } \\
\text { of measurement of } \\
\text { the variables, } \\
\text { number of groups } \\
\text { being compared, and } \\
\text { assumptions of the } \\
\text { texts? } \\
\text { Was a powerful } \\
\text { analytic method } \\
\text { used? (e.g., did the } \\
\text { analysis help to } \\
\text { control for } \\
\text { confounding } \\
\text { variables)? } \\
\text { Were type I and } \\
\text { Type II errors } \\
\text { avoided or } \\
\text { minimized? } \\
\text { In intervention } \\
\text { studies, was an }\end{array}$ & $\begin{array}{l}\text { Analyses were } \\
\text { undertaken to } \\
\text { address each } \\
\text { research question. } \\
\text { The univariate } \\
\text { analysis was } \\
\text { performed using a } \\
\text { two-sided t test, the } \\
\text { Pearson X2 test, and } \\
\text { the Fisher exact test } \\
\text { and it was performed } \\
\text { at two levels. These } \\
\text { were appropriate for } \\
\text { the level of } \\
\text { measurement of the } \\
\text { variables, number of } \\
\text { groups being } \\
\text { compared, and the } \\
\text { assumptions of the } \\
\text { texts. Type I and II } \\
\text { errors were avoided. } \\
\text { There was no } \\
\text { mention of an } \\
\text { intention-to-treat } \\
\text { analysis being } \\
\text { performed. Problems } \\
\text { of missing values }\end{array}$ \\
\hline
\end{tabular}




\begin{tabular}{|c|c|c|}
\hline & $\begin{array}{l}\text { intention-to-treat } \\
\text { analysis performed? } \\
\text { Were problems of } \\
\text { missing values } \\
\text { evaluated and } \\
\text { adequately } \\
\text { addressed? }\end{array}$ & $\begin{array}{l}\text { were evaluated and } \\
\text { adequately } \\
\text { addressed. }\end{array}$ \\
\hline Findings & $\begin{array}{l}\text { Was information } \\
\text { about statistical } \\
\text { significance } \\
\text { presented? Was } \\
\text { information about } \\
\text { effect size and } \\
\text { precision of } \\
\text { estimates } \\
\text { (confidence } \\
\text { intervals) presented? } \\
\text { Were the findings } \\
\text { adequately } \\
\text { summarized, with } \\
\text { good use of tables } \\
\text { and figures? } \\
\text { Were findings } \\
\text { reported in a manner } \\
\text { that facilitates a } \\
\text { meta-analysis, and } \\
\text { with sufficient } \\
\text { information needed } \\
\text { for EBP? }\end{array}$ & $\begin{array}{l}\text { Information about } \\
\text { statistical } \\
\text { significance was } \\
\text { presented. } \\
\text { Information about } \\
\text { effect size and } \\
\text { precision of } \\
\text { estimates were } \\
\text { presented. Findings } \\
\text { were adequately } \\
\text { summarized with } \\
\text { great use of tables } \\
\text { and figures. Findings } \\
\text { were reported in a } \\
\text { manner that } \\
\text { facilitates a meta- } \\
\text { analysis with } \\
\text { sufficient } \\
\text { information needed } \\
\text { for EBP. }\end{array}$ \\
\hline $\begin{array}{l}\text { Discussion } \\
\text { Interpretation of the Findings }\end{array}$ & $\begin{array}{l}\text { - Were all major } \\
\text { findings interpreted } \\
\text { and discussed within } \\
\text { the context of prior } \\
\text { research and/or the } \\
\text { study's conceptual } \\
\text { framework? } \\
\text { - Were casual } \\
\text { inferences, if any, } \\
\text { justified? } \\
\text { Was the issue of } \\
\text { clinical significance } \\
\text { discussed? } \\
\text { Were interpretations } \\
\text { well-founded and } \\
\text { consistent with the } \\
\text { study's limitations? }\end{array}$ & $\begin{array}{l}\text { All major findings } \\
\text { were interpreted and } \\
\text { discussed within the } \\
\text { context of prior } \\
\text { research. Casual } \\
\text { inferences were } \\
\text { justified. The issue } \\
\text { of clinical } \\
\text { significance was } \\
\text { discussed. The } \\
\text { interpretations were } \\
\text { well-founded and } \\
\text { consistent with the } \\
\text { study's limitations. } \\
\text { The report did } \\
\text { address the issue of } \\
\text { the generalizability }\end{array}$ \\
\hline
\end{tabular}




\begin{tabular}{|c|c|c|}
\hline & $\begin{array}{l}\text { - Did the report } \\
\text { address the issue of } \\
\text { the generalizability } \\
\text { of the findings? }\end{array}$ & of the findings. \\
\hline Implications/Recommendations & $\begin{array}{l}\text { Did the researchers } \\
\text { discuss the } \\
\text { implications of the } \\
\text { study for clinical } \\
\text { practice or further } \\
\text { research-and were } \\
\text { those implications } \\
\text { reasonable and } \\
\text { complete? }\end{array}$ & $\begin{array}{l}\text { The researchers } \\
\text { discussed the } \\
\text { implications of the } \\
\text { study for clinical } \\
\text { practice or further } \\
\text { research. They stated } \\
\text { that further studies } \\
\text { should be performed } \\
\text { including large-scale } \\
\text { randomized } \\
\text { controlled clinical } \\
\text { trials and additional } \\
\text { studies to validate } \\
\text { the application of the } \\
\text { decontamination } \\
\text { protocol to other } \\
\text { services implanting } \\
\text { hardware. }\end{array}$ \\
\hline $\begin{array}{l}\text { General Issues } \\
\text { Presentation }\end{array}$ & $\begin{array}{l}\text { Was the report well- } \\
\text { written, organized, } \\
\text { and sufficiently } \\
\text { detailed for critical } \\
\text { analysis? } \\
\text { - In intervention } \\
\text { studies, was a } \\
\text { CONSORT } \\
\text { flowchart provided } \\
\text { to show the flow of } \\
\text { participants in the } \\
\text { study? } \\
\text { Was the report } \\
\text { written in a manner } \\
\text { that makes the } \\
\text { findings accessible } \\
\text { to practicing nurses? }\end{array}$ & $\begin{array}{l}\text { The report was well- } \\
\text { written, organized, } \\
\text { and sufficiently } \\
\text { detailed for critical } \\
\text { analysis. There was a } \\
\text { CONSORT } \\
\text { flowchart provided } \\
\text { to show the flow of } \\
\text { participants in the } \\
\text { study. The report } \\
\text { was certainly written } \\
\text { in a manner that } \\
\text { makes the findings } \\
\text { accessible to } \\
\text { practicing nurses. }\end{array}$ \\
\hline Researcher Credibility & $\begin{array}{l}\text { Do the researchers' } \\
\text { clinical, substantive, } \\
\text { or methodologic } \\
\text { qualifications and } \\
\text { experience enhance } \\
\text { confidence in the } \\
\text { findings and their }\end{array}$ & $\begin{array}{l}\text { The researchers' } \\
\text { clinical, substantive, } \\
\text { and methodologic } \\
\text { qualifications and } \\
\text { experience enhance } \\
\text { confidence in the } \\
\text { findings and their }\end{array}$ \\
\hline
\end{tabular}




\begin{tabular}{|l|l|l|}
\hline interpretation? & $\begin{array}{l}\text { interpretation. They } \\
\text { were both from the } \\
\text { department of } \\
\text { surgery at Baylor } \\
\text { College of Medicine. }\end{array}$ \\
\hline Summary Assessment & $\begin{array}{l}\text { Despite any } \\
\text { limitations, do the } \\
\text { to the study, the } \\
\text { study findings } \\
\text { appear to be valid- } \\
\text { do you have } \\
\text { confidence in the } \\
\text { truth value of the } \\
\text { results? } \\
\text { Does the study and there can } \\
\text { contribute any } \\
\text { be confidence in the } \\
\text { truth value of the } \\
\text { results. This study } \\
\text { definitely } \\
\text { contributed } \\
\text { meaningful evidence } \\
\text { that can be used in } \\
\text { nursing practice or } \\
\text { that is useful to the } \\
\text { nursing discipline? }\end{array}$ & $\begin{array}{l}\text { that can be used in } \\
\text { nursing practice and } \\
\text { that is useful for the } \\
\text { nursing discipline. }\end{array}$ \\
\hline
\end{tabular}




\section{Appendix A-4}

Sai, N., Laurent, C., Strale, H., Denis, O., \& Byl., B. (2015). Efficacy of the decolonization of methicillin-resistant staphylococcus aureus carriers in clinical practice. Antimicrobial Resistance and Infection Control, 4(56), 1-8.

\begin{tabular}{|c|c|c|}
\hline Title & $\begin{array}{l}\text { - Is the title a good } \\
\text { one, succinctly } \\
\text { suggesting key } \\
\text { variables and the } \\
\text { study population? }\end{array}$ & $\begin{array}{l}\text { The title was } \\
\text { appropriate and } \\
\text { succinctly suggested } \\
\text { key variables and the } \\
\text { study population. }\end{array}$ \\
\hline Abstract & $\begin{array}{l}\text { Did the abstract } \\
\text { clearly and } \\
\text { concisely } \\
\text { summarize the } \\
\text { main features of } \\
\text { the report } \\
\text { (problem, } \\
\text { methods, results, } \\
\text { conclusions)? }\end{array}$ & $\begin{array}{l}\text { The abstract clearly } \\
\text { and concisely } \\
\text { summarized the main } \\
\text { features of the report. }\end{array}$ \\
\hline $\begin{array}{l}\text { Introduction } \\
\text { Statement of the Problem }\end{array}$ & $\begin{array}{l}\text { Was the problem } \\
\text { stated } \\
\text { unambiguously, } \\
\text { and was it easy to } \\
\text { identify? } \\
\text { - Is the problem } \\
\text { statement build a } \\
\text { persuasive } \\
\text { argument for the } \\
\text { new study? } \\
\text { Was there a good } \\
\text { match between } \\
\text { the research } \\
\text { problem and the } \\
\text { methods used - } \\
\text { that is, was a } \\
\text { quantitative } \\
\text { approach } \\
\text { appropriate? }\end{array}$ & $\begin{array}{l}\text { The problem was } \\
\text { stated unambiguously } \\
\text { and was easy to } \\
\text { identify. The problem } \\
\text { statement did build a } \\
\text { persuasive argument } \\
\text { for a new study, citing } \\
\text { that MRSA is } \\
\text { associated with a high } \\
\text { risk of acquiring } \\
\text { MRSA infection } \\
\text { during hospital stays. } \\
\text { There was a good } \\
\text { match between the } \\
\text { research problem and } \\
\text { the methods use; a } \\
\text { quantitative study was } \\
\text { appropriate. }\end{array}$ \\
\hline $\begin{array}{l}\text { Hypotheses or Research } \\
\text { Questions }\end{array}$ & $\begin{array}{l}\text { Were research } \\
\text { questions and/or } \\
\text { hypotheses } \\
\text { explicitly stated? } \\
\text { If not, was their } \\
\text { absence justified? } \\
\text { - Were questions } \\
\text { and hypotheses }\end{array}$ & $\begin{array}{l}\text { The research questions } \\
\text { were explicitly stated, } \\
\text { appropriately worded, } \\
\text { and with clear } \\
\text { specification of key } \\
\text { variables and the study } \\
\text { population, which was } \\
\text { identified as }\end{array}$ \\
\hline
\end{tabular}




\begin{tabular}{|c|c|c|}
\hline & $\begin{array}{l}\text { appropriately } \\
\text { worded, with } \\
\text { clear } \\
\text { specification of } \\
\text { key variables and } \\
\text { the study } \\
\text { population? } \\
\text { Were the } \\
\text { questions/hypoth } \\
\text { eses consistent } \\
\text { with existing } \\
\text { knowledge? }\end{array}$ & $\begin{array}{l}\text { hospitalized patients. } \\
\text { The research questions } \\
\text { were certainly } \\
\text { consistent with } \\
\text { existing knowledge. }\end{array}$ \\
\hline Literature Review & $\begin{array}{l}\text { Was the literature } \\
\text { review up-to-date } \\
\text { and based mainly } \\
\text { on primary } \\
\text { sources? } \\
\text { - Did the review } \\
\text { provide a state- } \\
\text { of-the-art } \\
\text { synthesis of } \\
\text { evidence on the } \\
\text { problem? } \\
\text { Did the literature } \\
\text { review provide a } \\
\text { strong basis for } \\
\text { the new study? }\end{array}$ & $\begin{array}{l}\text { The literature review is } \\
\text { fairly up-to-date with } \\
\text { most of the data being } \\
\text { from the early to mid- } \\
\text { 2000s. The review did } \\
\text { provide a state-of-the- } \\
\text { art synthesis of the } \\
\text { evidence on the } \\
\text { problem. The literature } \\
\text { review provided a } \\
\text { strong basis for the } \\
\text { new study citing there } \\
\text { was little information } \\
\text { about the rate of } \\
\text { success of } \\
\text { decolonization } \\
\text { strategies under real- } \\
\text { life conditions. }\end{array}$ \\
\hline $\begin{array}{l}\text { Conceptual/Theoretical } \\
\text { Framework }\end{array}$ & $\begin{array}{l}\text { Were key } \\
\text { concepts } \\
\text { adequately } \\
\text { defined } \\
\text { conceptually? } \\
\text { Was a } \\
\text { conceptual/theore } \\
\text { tical framework } \\
\text { articulated-and, } \\
\text { if so, was it } \\
\text { appropriate? If } \\
\text { not, is the } \\
\text { absence of a } \\
\text { framework } \\
\text { justified? } \\
\text { Were the }\end{array}$ & $\begin{array}{l}\text { Key concepts were } \\
\text { adequately defined } \\
\text { conceptually. There } \\
\text { was no theoretical } \\
\text { framework articulated } \\
\text { in this study and its } \\
\text { absence is justified in } \\
\text { this quantitative study. }\end{array}$ \\
\hline
\end{tabular}




\begin{tabular}{|c|c|c|}
\hline & $\begin{array}{l}\text { questions/hypoth } \\
\text { eses consistent } \\
\text { with the } \\
\text { framework? }\end{array}$ & \\
\hline $\begin{array}{l}\text { Method } \\
\text { Protection of Human Rights }\end{array}$ & $\begin{array}{l}\text { Were appropriate } \\
\text { procedures used } \\
\text { to safe-guard the } \\
\text { rights of study } \\
\text { participants? } \\
\text { Was the study } \\
\text { externally } \\
\text { reviewed by an } \\
\text { IRB/ethics } \\
\text { review board? } \\
\text { Was the study } \\
\text { designed to } \\
\text { minimize risks } \\
\text { and maximize } \\
\text { benefits to } \\
\text { participants? }\end{array}$ & $\begin{array}{l}\text { Appropriate } \\
\text { procedures were used } \\
\text { to safeguard the rights } \\
\text { of study participants. } \\
\text { There was no external } \\
\text { review by an } \\
\text { IRB/ethics review } \\
\text { board mentioned. The } \\
\text { study was designed to } \\
\text { minimize risks and } \\
\text { maximize benefits to } \\
\text { participants. }\end{array}$ \\
\hline Research Design & $\begin{array}{l}\text { Was the most } \\
\text { rigorous design } \\
\text { used, given the } \\
\text { study purpose? } \\
\text { - Were appropriate } \\
\text { comparisons } \\
\text { made to enhance } \\
\text { interpretability of } \\
\text { the findings? } \\
\text { Was the number } \\
\text { of data collection } \\
\text { points } \\
\text { appropriate? } \\
\text { Did the design } \\
\text { minimize biases } \\
\text { and threats to the } \\
\text { internal, } \\
\text { construct, and } \\
\text { external validity } \\
\text { of the study (e.g., } \\
\text { was blinding } \\
\text { used, was } \\
\text { attrition } \\
\text { minimized)? }\end{array}$ & $\begin{array}{l}\text { Given the study } \\
\text { purpose, the most } \\
\text { rigorous design was } \\
\text { used. Appropriate } \\
\text { comparisons were } \\
\text { made to enhance } \\
\text { interpretability of the } \\
\text { findings. The number } \\
\text { of data collection } \\
\text { points was appropriate } \\
\text { for this study. The } \\
\text { design certainly } \\
\text { minimized biases and } \\
\text { threats to internal, } \\
\text { construct, and external } \\
\text { validity of the study. }\end{array}$ \\
\hline Population and Sample & $\begin{array}{l}\text { - Was the } \\
\text { population }\end{array}$ & $\begin{array}{l}\text { The population was } \\
\text { identified as inpatients }\end{array}$ \\
\hline
\end{tabular}




\begin{tabular}{|c|c|c|}
\hline & $\begin{array}{l}\text { identified? Was } \\
\text { the sample } \\
\text { described in } \\
\text { sufficient detail? } \\
\text { - Was the best } \\
\text { possible sampling } \\
\text { design used to } \\
\text { enhance the } \\
\text { sample's } \\
\text { representativenes } \\
\text { s? Were } \\
\text { sampling biases } \\
\text { minimized? } \\
\text { Was the sample } \\
\text { size based on a } \\
\text { power analysis? }\end{array}$ & $\begin{array}{l}\text { in an 864-bed } \\
\text { academic hospital in } \\
\text { Belgium. The best } \\
\text { possible sampling } \\
\text { design was used to } \\
\text { enhance the sample's } \\
\text { representativeness. } \\
\text { Sampling biases were } \\
\text { minimized. There was } \\
\text { no mention of a power } \\
\text { analysis. It appears the } \\
\text { sample size was based } \\
\text { on a convenience } \\
\text { sample. The study } \\
\text { population consisted of } \\
\text { all patients diagnosed } \\
\text { as MRSA-positive } \\
\text { between January } 2006 \\
\text { and June } 2010 \text {. }\end{array}$ \\
\hline $\begin{array}{l}\text { Data Collection and } \\
\text { Measurement }\end{array}$ & $\begin{array}{l}\text { Were the } \\
\text { operational and } \\
\text { conceptual } \\
\text { definitions } \\
\text { congruent? } \\
\text { Were key } \\
\text { variables } \\
\text { measured using } \\
\text { an appropriate } \\
\text { method (e.g., } \\
\text { interviews, } \\
\text { observations, and } \\
\text { so on)? } \\
\text { Were specific } \\
\text { instruments } \\
\text { adequately } \\
\text { described and } \\
\text { were they good } \\
\text { choices, given the } \\
\text { study population } \\
\text { and the variables } \\
\text { being studied? } \\
\text { Did the report } \\
\text { provide evidence } \\
\text { that the data } \\
\text { collection } \\
\text { methods yielded }\end{array}$ & $\begin{array}{l}\text { The operational and } \\
\text { conceptual definitions } \\
\text { were congruent. Key } \\
\text { variables were } \\
\text { measured using a data } \\
\text { collection tool and } \\
\text { statistical analysis, } \\
\text { appropriate for this } \\
\text { quantitative study. The } \\
\text { authors created their } \\
\text { own data collection } \\
\text { tool, which is } \\
\text { appropriate for this } \\
\text { quantitative study. The } \\
\text { report provided } \\
\text { evidence that the data } \\
\text { collection methods } \\
\text { yielded data that were } \\
\text { reliable, valid, and } \\
\text { responsive. }\end{array}$ \\
\hline
\end{tabular}




\begin{tabular}{|c|c|c|}
\hline & $\begin{array}{l}\text { data that were } \\
\text { reliable, valid and } \\
\text { responsive? }\end{array}$ & \\
\hline Procedures & $\begin{array}{l}\text { - If there was an } \\
\text { intervention, was } \\
\text { it adequately } \\
\text { described, and } \\
\text { was it rigorously } \\
\text { developed and } \\
\text { implemented? } \\
\text { Did most } \\
\text { participants } \\
\text { allocated to the } \\
\text { intervention } \\
\text { group actually } \\
\text { receive it? Was } \\
\text { there evidence of } \\
\text { intervention } \\
\text { fidelity? } \\
\text { Were data } \\
\text { collected in a } \\
\text { manner that } \\
\text { minimized bias? } \\
\text { Were the staff } \\
\text { who collected } \\
\text { data } \\
\text { appropriately } \\
\text { trained? }\end{array}$ & $\begin{array}{l}\text { The intervention was } \\
\text { described as } \\
\text { application of } \\
\text { intranasal mupirocin } \\
\text { and washing with } \\
\text { chlorhexidine soap or } \\
\text { application of } \\
\text { intranasal povidone- } \\
\text { iodine and washing } \\
\text { with povidone-iodine } \\
\text { soap, each treatment } \\
\text { lasting for five days. } \\
\text { The intranasal } \\
\text { mupirocin/chlorhexidi } \\
\text { ne wash group was } \\
\text { administered to } \\
\text { uncomplicated cases } \\
\text { and the povidone- } \\
\text { iodine intranasal/soap } \\
\text { group was } \\
\text { administered to the } \\
\text { more complicated } \\
\text { cases. The complicated } \\
\text { and uncomplicated } \\
\text { criteria are listed in a } \\
\text { figure in the study. } \\
\text { The intervention was } \\
\text { more than adequately } \\
\text { described and was } \\
\text { rigorously developed } \\
\text { and implemented. All } \\
\text { patients in the } \\
\text { intervention group } \\
\text { actually received the } \\
\text { intervention. Those } \\
\text { that did not were } \\
\text { excluded from the } \\
\text { study. Data were } \\
\text { collected in a manner } \\
\text { that minimized bias, in } \\
\text { a retrospective } \\
\text { manner. }\end{array}$ \\
\hline
\end{tabular}




\begin{tabular}{|c|c|c|}
\hline Data Analysis & $\begin{array}{l}\text { Were analyses } \\
\text { undertaken to } \\
\text { address each } \\
\text { research question } \\
\text { or test each } \\
\text { hypothesis? } \\
\text { - Were appropriate } \\
\text { statistical } \\
\text { methods used, } \\
\text { given the level of } \\
\text { measurement of } \\
\text { the variables, } \\
\text { number of groups } \\
\text { being compared, } \\
\text { and assumptions } \\
\text { of the texts? } \\
\text { Was a powerful } \\
\text { analytic method } \\
\text { used? (e.g., did } \\
\text { the analysis help } \\
\text { to control for } \\
\text { confounding } \\
\text { variables)? } \\
\text { Were type I and } \\
\text { Type II errors } \\
\text { avoided or } \\
\text { minimized? } \\
\text { In intervention } \\
\text { studies, was an } \\
\text { intention-to-treat } \\
\text { analysis } \\
\text { performed? } \\
\text { Were problems } \\
\text { of missing values } \\
\text { evaluated and } \\
\text { adequately } \\
\text { addressed? }\end{array}$ & $\begin{array}{l}\text { Analyses were } \\
\text { undertaken to address } \\
\text { each research question. } \\
\text { The appropriate } \\
\text { statistical methods } \\
\text { were used given the } \\
\text { level of measurement } \\
\text { of the variables, } \\
\text { number of groups } \\
\text { being compared, and } \\
\text { assumptions of the } \\
\text { texts. A powerful } \\
\text { analytic method was } \\
\text { used described as the } \\
\text { Epi Info } 7 \text {. Normally } \\
\text { distributed continuous } \\
\text { variables were } \\
\text { compared using a } 2 \text { - } \\
\text { sample t test, and } \\
\text { categorical data were } \\
\text { compared using a X2 } \\
\text { test with a Yates } \\
\text { correction. Type I and } \\
\text { type II errors were } \\
\text { avoided. There was no } \\
\text { mention of an } \\
\text { intention-to-treat } \\
\text { analysis being } \\
\text { performed. Problems } \\
\text { of missing values were } \\
\text { evaluated and adequate } \\
\text { addressed specifically } \\
\text { in this study. }\end{array}$ \\
\hline Findings & $\begin{array}{l}\text { - Was information } \\
\text { about statistical } \\
\text { significance } \\
\text { presented? Was } \\
\text { information about } \\
\text { effect size and } \\
\text { precision of } \\
\text { estimates } \\
\text { (confidence }\end{array}$ & $\begin{array}{l}\text { Information about } \\
\text { statistical significance } \\
\text { was presented. } \\
\text { Information about } \\
\text { confidence intervals } \\
\text { was presented. The } \\
\text { findings were } \\
\text { adequately } \\
\text { summarized with }\end{array}$ \\
\hline
\end{tabular}




\begin{tabular}{|c|c|c|}
\hline & $\begin{array}{l}\text { intervals) } \\
\text { presented? } \\
\text { - Were the findings } \\
\text { adequately } \\
\text { summarized, with } \\
\text { good use of } \\
\text { tables and } \\
\text { figures? } \\
\text { Were findings } \\
\text { reported in a } \\
\text { manner that } \\
\text { facilitates a meta- } \\
\text { analysis, and with } \\
\text { sufficient } \\
\text { information } \\
\text { needed for EBP? }\end{array}$ & $\begin{array}{l}\text { appropriate use of } \\
\text { tables. The findings } \\
\text { were reported in a } \\
\text { manner that facilitates } \\
\text { a meta-analysis and } \\
\text { with sufficient } \\
\text { information needed for } \\
\text { EBP. }\end{array}$ \\
\hline $\begin{array}{l}\text { Discussion } \\
\text { Interpretation of the Findings }\end{array}$ & $\begin{array}{l}\text { Were all major } \\
\text { findings } \\
\text { interpreted and } \\
\text { discussed within } \\
\text { the context of } \\
\text { prior research } \\
\text { and/or the study's } \\
\text { conceptual } \\
\text { framework? } \\
\text { Were casual } \\
\text { inferences, if any, } \\
\text { justified? } \\
\text { Was the issue of } \\
\text { clinical } \\
\text { significance } \\
\text { discussed? } \\
\text { Were } \\
\text { interpretations } \\
\text { well-founded and } \\
\text { consistent with } \\
\text { the study's } \\
\text { limitations? } \\
\text { Did the report } \\
\text { address the issue } \\
\text { of the } \\
\text { generalizability } \\
\text { of the findings? }\end{array}$ & $\begin{array}{l}\text { All major findings } \\
\text { were interpreted and } \\
\text { discussed within the } \\
\text { context of prior } \\
\text { research. The issue of } \\
\text { clinical significance } \\
\text { was certainly } \\
\text { discussed. The } \\
\text { interpretations were } \\
\text { well-founded and } \\
\text { consistent with the } \\
\text { study's limitations. } \\
\text { The report does } \\
\text { address the issue of the } \\
\text { generalizability of the } \\
\text { findings, stating there } \\
\text { was a low rate of } \\
\text { successful treatment. } \\
\text { This is believed to } \\
\text { have been due to the } \\
\text { use of povidone-iodine } \\
\text { being restricted to only } \\
\text { the complicated cases. } \\
\text { There were also more } \\
\text { patients included in } \\
\text { this study with less } \\
\text { than ideal prognostic } \\
\text { factors such as those } \\
\text { with chronic wounds, } \\
\text { which are }\end{array}$ \\
\hline
\end{tabular}




\begin{tabular}{|c|c|c|}
\hline & & $\begin{array}{l}\text { contraindicated in } \\
\text { most other studies. }\end{array}$ \\
\hline Implications/Recommendations & $\begin{array}{l}\text { Did the } \\
\text { researchers } \\
\text { discuss the } \\
\text { implications of } \\
\text { the study for } \\
\text { clinical practice } \\
\text { or further } \\
\text { research-and } \\
\text { were those } \\
\text { implications } \\
\text { reasonable and } \\
\text { complete? }\end{array}$ & $\begin{array}{l}\text { The researchers } \\
\text { discussed the } \\
\text { implications of the } \\
\text { study for clinical } \\
\text { practice and they } \\
\text { recommend that } \\
\text { systematic topical } \\
\text { decolonization in } \\
\text { MRSA carrier be } \\
\text { undertaken in } \\
\text { accordance with recent } \\
\text { proposals made by } \\
\text { other researchers. }\end{array}$ \\
\hline $\begin{array}{l}\text { General Issues } \\
\text { Presentation }\end{array}$ & $\begin{array}{l}\text { Was the report } \\
\text { well-written, } \\
\text { organized, and } \\
\text { sufficiently } \\
\text { detailed for } \\
\text { critical analysis? } \\
\text { - In intervention } \\
\text { studies, was a } \\
\text { CONSORT } \\
\text { flowchart } \\
\text { provided to show } \\
\text { the flow of } \\
\text { participants in the } \\
\text { study? } \\
\text { Was the report } \\
\text { written in a } \\
\text { manner that } \\
\text { makes the } \\
\text { findings } \\
\text { accessible to } \\
\text { practicing } \\
\text { nurses? }\end{array}$ & $\begin{array}{l}\text { The report was } \\
\text { definitely well-written, } \\
\text { organized, and } \\
\text { sufficiently detailed } \\
\text { for critical analysis. A } \\
\text { CONSORT flowchart } \\
\text { was provided to show } \\
\text { the flow of participants } \\
\text { in the study. The } \\
\text { report was definitely } \\
\text { written in a manner } \\
\text { that makes the findings } \\
\text { accessible to practicing } \\
\text { nurses. }\end{array}$ \\
\hline Researcher Credibility & $\begin{array}{l}\text { Do the } \\
\text { researchers' } \\
\text { clinical, } \\
\text { substantive, or } \\
\text { methodologic } \\
\text { qualifications and } \\
\text { experience } \\
\text { enhance } \\
\text { confidence in the }\end{array}$ & $\begin{array}{l}\text { While there is no } \\
\text { mention of the } \\
\text { researcher's clinical, } \\
\text { substantive, or } \\
\text { methodologic } \\
\text { qualifications and } \\
\text { experience, one of the } \\
\text { authors, Sai, worked } \\
\text { for the Hospital }\end{array}$ \\
\hline
\end{tabular}




\begin{tabular}{|c|c|c|}
\hline & $\begin{array}{l}\text { findings and their } \\
\text { interpretation? }\end{array}$ & $\begin{array}{l}\text { Epidemiology and } \\
\text { Infection Control Unit, } \\
\text { so it would seem he } \\
\text { has clinical } \\
\text { qualifications. }\end{array}$ \\
\hline Summary Assessment & $\begin{array}{l}\text { Despite any } \\
\text { limitations, do } \\
\text { the study findings } \\
\text { appear to be } \\
\text { valid-do you } \\
\text { have confidence } \\
\text { in the truth value } \\
\text { of the results? } \\
\text { Does the study } \\
\text { contribute any } \\
\text { meaningful } \\
\text { evidence that can } \\
\text { be used in } \\
\text { nursing practice } \\
\text { or that is useful } \\
\text { to the nursing } \\
\text { discipline? }\end{array}$ & $\begin{array}{l}\text { Despite any } \\
\text { limitations, the study } \\
\text { findings do appear to } \\
\text { be valid, although this } \\
\text { study could have } \\
\text { benefitted from a } \\
\text { larger sample size. } \\
\text { This study does } \\
\text { contribute to } \\
\text { meaningful evidence } \\
\text { that can be used in } \\
\text { nursing practice and } \\
\text { will be useful to the } \\
\text { nursing discipline as } \\
\text { the authors further } \\
\text { demonstrate the } \\
\text { effectiveness of } \\
\text { decolonization on the } \\
\text { infection rates. }\end{array}$ \\
\hline
\end{tabular}




\section{Appendix A-5}

Peng, H. M., Wang, L. C., Zhai, J. L., Weng, X. S., Feng, B., \& Wang, W. (2018). Effectiveness of preoperative decolonization with nasal povidone iodine in chinese patients undergoing elective orthopedic surgery: A prospective crosssectional study. Brazilian Journal of Medical and Biological Research, 51(2), 1-6.

\begin{tabular}{|c|c|c|}
\hline Title & $\begin{array}{l}\text { Is the title a good } \\
\text { one, succinctly } \\
\text { suggesting key } \\
\text { variables and the } \\
\text { study population? }\end{array}$ & $\begin{array}{l}\text { The title was very } \\
\text { informative, } \\
\text { suggesting key } \\
\text { variables and } \\
\text { identifying the } \\
\text { study population as } \\
\text { Chinese patients. }\end{array}$ \\
\hline Abstract & $\begin{array}{l}\text { Did the abstract } \\
\text { clearly and concisely } \\
\text { summarize the main } \\
\text { features of the report } \\
\text { (problem, methods, } \\
\text { results, } \\
\text { conclusions)? }\end{array}$ & $\begin{array}{l}\text { The abstract } \\
\text { concisely } \\
\text { summarized the } \\
\text { main features of the } \\
\text { report including the } \\
\text { problem, methods, } \\
\text { results, and } \\
\text { conclusions. }\end{array}$ \\
\hline $\begin{array}{l}\text { Introduction } \\
\text { Statement of the Problem }\end{array}$ & $\begin{array}{l}\text { Was the problem } \\
\text { stated } \\
\text { unambiguously, and } \\
\text { was it easy to } \\
\text { identify? } \\
\text { - Is the problem } \\
\text { statement build a } \\
\text { persuasive argument } \\
\text { for the new study? } \\
\text { Was there a good } \\
\text { match between the } \\
\text { research problem } \\
\text { and the methods } \\
\text { used -that is, was a } \\
\text { quantitative } \\
\text { approach } \\
\text { appropriate? }\end{array}$ & $\begin{array}{l}\text { The problem was } \\
\text { stated } \\
\text { unambiguously and } \\
\text { it was easy to } \\
\text { identify. The } \\
\text { problem statement } \\
\text { does build a } \\
\text { persuasive argument } \\
\text { for the new study. } \\
\text { The authors cited } \\
\text { the fact that there } \\
\text { was data lacking } \\
\text { regarding the } \\
\text { prevalence and } \\
\text { distribution of } \\
\text { MSSA and MRSA } \\
\text { in patients } \\
\text { undergoing } \\
\text { orthopedic surgery } \\
\text { in China. A } \\
\text { quantitative study } \\
\text { was appropriate for } \\
\text { the stated research } \\
\text { problem. }\end{array}$ \\
\hline
\end{tabular}




\begin{tabular}{|c|c|c|}
\hline $\begin{array}{l}\text { Hypotheses or Research } \\
\text { Questions }\end{array}$ & $\begin{array}{l}\text { - Were research } \\
\text { questions and/or } \\
\text { hypotheses explicitly } \\
\text { stated? If not, was } \\
\text { their absence } \\
\text { justified? } \\
\text { - Were questions and } \\
\text { hypotheses } \\
\text { appropriately } \\
\text { worded, with clear } \\
\text { specification of key } \\
\text { variables and the } \\
\text { study population? } \\
\text { Were the } \\
\text { questions/hypotheses } \\
\text { consistent with } \\
\text { existing knowledge? }\end{array}$ & $\begin{array}{l}\text { The research } \\
\text { question was } \\
\text { explicitly stated. } \\
\text { The question was } \\
\text { appropriately } \\
\text { worded with clear } \\
\text { specification of key } \\
\text { variables and the } \\
\text { study population. } \\
\text { The question was } \\
\text { consistent with } \\
\text { existing knowledge. }\end{array}$ \\
\hline Literature Review & $\begin{array}{l}\text { Was the literature } \\
\text { review up-to-date } \\
\text { and based mainly on } \\
\text { primary sources? } \\
\text { - } \text { Did the review } \\
\text { provide a state-of- } \\
\text { the-art synthesis of } \\
\text { evidence on the } \\
\text { problem? } \\
\text { Did the literature } \\
\text { review provide a } \\
\text { strong basis for the } \\
\text { new study? }\end{array}$ & $\begin{array}{l}\text { The literature was } \\
\text { fairly up to date, } \\
\text { dating as far back as } \\
2002 \text {. There was a } \\
\text { state-of-the art } \\
\text { synthesis of } \\
\text { evidence on the } \\
\text { problem provided. } \\
\text { The literature } \\
\text { review provided a } \\
\text { strong basis for the } \\
\text { new study citing a } \\
\text { lack of similar } \\
\text { studies in China. }\end{array}$ \\
\hline $\begin{array}{l}\text { Conceptual/Theoretical } \\
\text { Framework }\end{array}$ & $\begin{array}{l}\text { Were key concepts } \\
\text { adequately defined } \\
\text { conceptually? } \\
\text { Was a } \\
\text { conceptual/theoretic } \\
\text { al framework } \\
\text { articulated - and, if } \\
\text { so, was it } \\
\text { appropriate? If not, } \\
\text { is the absence of a } \\
\text { framework justified? } \\
\text { Were the } \\
\text { questions/hypotheses } \\
\text { consistent with the } \\
\text { framework? }\end{array}$ & $\begin{array}{l}\text { Key concepts were } \\
\text { adequately defined } \\
\text { conceptually. There } \\
\text { was no conceptual/ } \\
\text { theoretical } \\
\text { framework } \\
\text { articulated. The } \\
\text { absence of the } \\
\text { framework was not } \\
\text { justified. }\end{array}$ \\
\hline
\end{tabular}




\begin{tabular}{|c|c|c|}
\hline $\begin{array}{l}\text { Method } \\
\text { Protection of Human Rights }\end{array}$ & $\begin{array}{l}\text { - Were appropriate } \\
\text { procedures used to } \\
\text { safeguard the rights } \\
\text { of study } \\
\text { participants? } \\
\text { - Was the study } \\
\text { externally reviewed } \\
\text { by an IRB/ethics } \\
\text { review board? } \\
\text { Was the study } \\
\text { designed to } \\
\text { minimize risks and } \\
\text { maximize benefits to } \\
\text { participants? }\end{array}$ & $\begin{array}{l}\text { Appropriate } \\
\text { procedures were } \\
\text { used to safeguard } \\
\text { the right of study } \\
\text { participants and } \\
\text { informed consent } \\
\text { was obtained from } \\
\text { the patients before } \\
\text { they were swabbed. } \\
\text { The study was } \\
\text { approved by the } \\
\text { Institutional Ethics } \\
\text { Committee of } \\
\text { Peking Union } \\
\text { Medical College } \\
\text { Hospital. The study } \\
\text { was designed to } \\
\text { minimize risks and } \\
\text { maximize benefits } \\
\text { to study } \\
\text { participants. }\end{array}$ \\
\hline Research Design & $\begin{array}{l}\text { Was the most } \\
\text { rigorous design } \\
\text { used, given the study } \\
\text { purpose? } \\
\text { Were appropriate } \\
\text { comparisons made to } \\
\text { enhance } \\
\text { interpretability of the } \\
\text { findings? } \\
\text { Was the number of } \\
\text { data collection } \\
\text { points appropriate? } \\
\text { Did the design } \\
\text { minimize biases and } \\
\text { threats to the } \\
\text { internal, construct, } \\
\text { and external validity } \\
\text { of the study (e.g., } \\
\text { was blinding used, } \\
\text { was attrition } \\
\text { minimized)? }\end{array}$ & $\begin{array}{l}\text { The most rigorous } \\
\text { design was used } \\
\text { given the purpose of } \\
\text { the study. The } \\
\text { appropriate } \\
\text { comparisons were } \\
\text { made to enhance } \\
\text { interpretability of } \\
\text { the findings. The } \\
\text { number of data } \\
\text { collection points } \\
\text { were appropriate. } \\
\text { Blinding was not } \\
\text { used. }\end{array}$ \\
\hline Population and Sample & $\begin{array}{l}\text { Was the population } \\
\text { identified? Was the } \\
\text { sample described in } \\
\text { sufficient detail? }\end{array}$ & $\begin{array}{l}\text { The study } \\
\text { population was } \\
\text { identified and } \\
\text { described in }\end{array}$ \\
\hline
\end{tabular}




\begin{tabular}{|c|c|c|}
\hline & $\begin{array}{l}\text { Was the best } \\
\text { possible sampling } \\
\text { design used to } \\
\text { enhance the } \\
\text { sample's } \\
\text { representativeness? } \\
\text { Were sampling } \\
\text { biases minimized? } \\
\text { Was the sample size } \\
\text { based on a power } \\
\text { analysis? }\end{array}$ & $\begin{array}{l}\text { sufficient detail. } \\
\text { The sampling } \\
\text { design used was a } \\
\text { prospective cross- } \\
\text { sectional study. } \\
\text { Patients were } \\
\text { selected } \\
\text { consecutively from } \\
\text { those who were } \\
\text { undergoing elective } \\
\text { orthopedic surgery } \\
\text { between August } \\
2015 \text { and February } \\
2016 \text {. The minimum } \\
\text { sample size was } \\
\text { calculated to be } 457 \\
\text { patients in order to } \\
\text { detect the } \\
\text { prevalence with a } \\
2 \% \text { precision. }\end{array}$ \\
\hline $\begin{array}{l}\text { Data Collection and } \\
\text { Measurement }\end{array}$ & $\begin{array}{l}\text { Were the operational } \\
\text { and conceptual } \\
\text { definitions } \\
\text { congruent? } \\
\text { - Were key variables } \\
\text { measured using an } \\
\text { appropriate method } \\
\text { (e.g., interviews, } \\
\text { observations, and so } \\
\text { on)? } \\
\text { Were specific } \\
\text { instruments } \\
\text { adequately described } \\
\text { and were they good } \\
\text { choices, given the } \\
\text { study population and } \\
\text { the variables being } \\
\text { studied? } \\
\text { Did the report } \\
\text { provide evidence } \\
\text { that the data } \\
\text { collection methods } \\
\text { yielded data that } \\
\text { were reliable, valid } \\
\text { and responsive? }\end{array}$ & $\begin{array}{l}\text { Operational and } \\
\text { conceptual } \\
\text { definitions were } \\
\text { congruent. Key } \\
\text { variables were } \\
\text { measured } \\
\text { appropriately using } \\
\text { data collection as } \\
\text { well as a } \\
\text { questionnaire } \\
\text { completed by each } \\
\text { patient in order to } \\
\text { evaluate each } \\
\text { patients' } \\
\text { characteristics. } \\
\text { Specific instruments } \\
\text { were adequately } \\
\text { described and were } \\
\text { appropriate choices } \\
\text { given the study } \\
\text { population. }\end{array}$ \\
\hline
\end{tabular}




\begin{tabular}{|c|c|c|}
\hline Procedures & $\begin{array}{l}\text { - If there was an } \\
\text { intervention, was it } \\
\text { adequately } \\
\text { described, and was it } \\
\text { rigorously developed } \\
\text { and implemented? } \\
\text { Did most } \\
\text { participants } \\
\text { allocated to the } \\
\text { intervention group } \\
\text { actually receive it? } \\
\text { Was there evidence } \\
\text { of intervention } \\
\text { fidelity? } \\
\text { Were data collected } \\
\text { in a manner that } \\
\text { minimized bias? } \\
\text { Were the staff who } \\
\text { collected data } \\
\text { appropriately } \\
\text { trained? }\end{array}$ & $\begin{array}{l}\text { There was an } \\
\text { intervention and it } \\
\text { was adequately } \\
\text { identified and } \\
\text { described as well as } \\
\text { rigorously } \\
\text { developed and } \\
\text { implemented. There } \\
\text { were } 33 \text { patients } \\
\text { excluded from the } \\
\text { study who did not } \\
\text { receive any } \\
\text { intervention. There } \\
\text { was evidence of } \\
\text { intervention fidelity. } \\
\text { Data were collected } \\
\text { in a manner that } \\
\text { minimized bias and } \\
\text { the staff who } \\
\text { collected the data } \\
\text { were appropriately } \\
\text { trained. }\end{array}$ \\
\hline Data Analysis & $\begin{array}{l}\text { Were analyses } \\
\text { undertaken to } \\
\text { address each } \\
\text { research question or } \\
\text { test each hypothesis? } \\
\text { - Were appropriate } \\
\text { statistical methods } \\
\text { used, given the level } \\
\text { of measurement of } \\
\text { the variables, } \\
\text { number of groups } \\
\text { being compared, and } \\
\text { assumptions of the } \\
\text { texts? } \\
\text { Was a powerful } \\
\text { analytic method } \\
\text { used? (e.g., did the } \\
\text { analysis help to } \\
\text { control for } \\
\text { confounding } \\
\text { variables)? } \\
\text { Were type I and } \\
\text { Type II errors } \\
\text { avoided or }\end{array}$ & $\begin{array}{l}\text { Analyses were } \\
\text { undertaken to } \\
\text { address the research } \\
\text { question. All } \\
\text { statistical analyses } \\
\text { were performed } \\
\text { using the software } \\
\text { SPSS. The } \\
\text { statistical analyses } \\
\text { comparing the pre- } \\
\text { operative results } \\
\text { were performed } \\
\text { using the McNemar } \\
\text { test. Type I and type } \\
\text { II errors were } \\
\text { minimized. There } \\
\text { was no mention of } \\
\text { an intention-to-treat } \\
\text { analysis being } \\
\text { performed. } \\
\text { Problems of missing } \\
\text { values were } \\
\text { evaluated and } \\
\text { adequately }\end{array}$ \\
\hline
\end{tabular}




\begin{tabular}{|c|c|c|}
\hline & $\begin{array}{l}\text { minimized? } \\
\text { In intervention } \\
\text { studies, was an } \\
\text { intention-to-treat } \\
\text { analysis performed? } \\
\text { - Were problems of } \\
\text { missing values } \\
\text { evaluated and } \\
\text { adequately } \\
\text { addressed? }\end{array}$ & addressed. \\
\hline Findings & $\begin{array}{l}\text { Was information } \\
\text { about statistical } \\
\text { significance } \\
\text { presented? Was } \\
\text { information about } \\
\text { effect size and } \\
\text { precision of } \\
\text { estimates } \\
\text { (confidence } \\
\text { intervals) presented? } \\
\text { Were the findings } \\
\text { adequately } \\
\text { summarized, with } \\
\text { good use of tables } \\
\text { and figures? } \\
\text { Were findings } \\
\text { reported in a manner } \\
\text { that facilitates a } \\
\text { meta-analysis, and } \\
\text { with sufficient } \\
\text { information needed } \\
\text { for EBP? }\end{array}$ & $\begin{array}{l}\text { Information about } \\
\text { statistical } \\
\text { significance was } \\
\text { presented. There } \\
\text { was information } \\
\text { about effect size and } \\
\text { precision of } \\
\text { estimates presented. } \\
\text { The findings were } \\
\text { adequately } \\
\text { summarized but the } \\
\text { tables and figures } \\
\text { could have used } \\
\text { further elaboration. } \\
\text { The findings were } \\
\text { reported in a } \\
\text { manner that } \\
\text { facilitated a meta- } \\
\text { analysis with } \\
\text { sufficient } \\
\text { information needed } \\
\text { for EBP. }\end{array}$ \\
\hline $\begin{array}{l}\text { Discussion } \\
\text { Interpretation of the Findings }\end{array}$ & $\begin{array}{l}\text { Were all major } \\
\text { findings interpreted } \\
\text { and discussed within } \\
\text { the context of prior } \\
\text { research and/or the } \\
\text { study's conceptual } \\
\text { framework? } \\
\text { - Were casual } \\
\text { inferences, if any, } \\
\text { justified? } \\
\text { - Was the issue of } \\
\text { clinical significance } \\
\text { discussed? } \\
\text { - Were interpretations }\end{array}$ & $\begin{array}{l}\text { All major findings } \\
\text { were interpreted and } \\
\text { discussed within the } \\
\text { context of prior } \\
\text { research. Casual } \\
\text { inferences were } \\
\text { justified. The } \\
\text { clinical significance } \\
\text { was discussed. The } \\
\text { interpretations were } \\
\text { well-founded and } \\
\text { consistent with the } \\
\text { study's limitations. } \\
\text { The report did }\end{array}$ \\
\hline
\end{tabular}




\begin{tabular}{|c|c|c|}
\hline & $\begin{array}{l}\text { well-founded and } \\
\text { consistent with the } \\
\text { study's limitations? } \\
\text { Did the report } \\
\text { address the issue of } \\
\text { the generalizability } \\
\text { of the findings? }\end{array}$ & $\begin{array}{l}\text { address the } \\
\text { generalizability of } \\
\text { the findings. }\end{array}$ \\
\hline Implications/Recommendations & $\begin{array}{l}\text { Did the researchers } \\
\text { discuss the } \\
\text { implications of the } \\
\text { study for clinical } \\
\text { practice or further } \\
\text { research - and were } \\
\text { those implications } \\
\text { reasonable and } \\
\text { complete? }\end{array}$ & $\begin{array}{l}\text { The researchers did } \\
\text { discuss the } \\
\text { implications of the } \\
\text { study for clinical } \\
\text { practice and further } \\
\text { research. They } \\
\text { suggested that the } \\
\text { nasal povidone- } \\
\text { iodine swabs should } \\
\text { be used to eradicate } \\
\text { nasal colonization } \\
\text { of MRSA/MSSA } \\
\text { and they also } \\
\text { suggested that } \\
\text { research with a } \\
\text { larger cohort of } \\
\text { orthopedic surgery } \\
\text { patients be } \\
\text { performed to } \\
\text { determine its } \\
\text { efficacy in } \\
\text { eradicating } \\
\text { MRSA/MSSA } \\
\text { colonization. }\end{array}$ \\
\hline $\begin{array}{l}\text { General Issues } \\
\text { Presentation }\end{array}$ & $\begin{array}{l}\text { Was the report well- } \\
\text { written, organized, } \\
\text { and sufficiently } \\
\text { detailed for critical } \\
\text { analysis? } \\
\text { - In intervention } \\
\text { studies, was a } \\
\text { CONSORT } \\
\text { flowchart provided } \\
\text { to show the flow of } \\
\text { participants in the } \\
\text { study? } \\
\text { Was the report } \\
\text { written in a manner } \\
\text { that makes the }\end{array}$ & $\begin{array}{l}\text { The report was very } \\
\text { well written, } \\
\text { organized, and } \\
\text { sufficiently detailed } \\
\text { for critical analysis. } \\
\text { A CONSORT } \\
\text { flowchart was } \\
\text { provided to show } \\
\text { the flow of } \\
\text { participants in the } \\
\text { study. The report } \\
\text { was written in a } \\
\text { manner that made } \\
\text { the findings } \\
\text { accessible to }\end{array}$ \\
\hline
\end{tabular}




\begin{tabular}{|c|c|c|}
\hline & $\begin{array}{l}\text { findings accessible } \\
\text { to practicing nurses? }\end{array}$ & practicing nurses. \\
\hline Researcher Credibility & $\begin{array}{l}\text { Do the researchers' } \\
\text { clinical, substantive, } \\
\text { or methodologic } \\
\text { qualifications and } \\
\text { experience enhance } \\
\text { confidence in the } \\
\text { findings and their } \\
\text { interpretation? }\end{array}$ & $\begin{array}{l}\text { The credentials of } \\
\text { the researchers were } \\
\text { not identified, but } \\
\text { the study was } \\
\text { performed by the } \\
\text { department of } \\
\text { orthopedic surgery. } \\
\text { It can be expected } \\
\text { that members would } \\
\text { have the experience } \\
\text { necessary to } \\
\text { enhance confidence } \\
\text { in the findings and } \\
\text { their interpretations. }\end{array}$ \\
\hline Summary Assessment & $\begin{array}{l}\text { Despite any } \\
\text { limitations, do the } \\
\text { study findings } \\
\text { appear to be valid- } \\
\text { do you have } \\
\text { confidence in the } \\
\text { truth value of the } \\
\text { results? } \\
\text { Does the study } \\
\text { contribute any } \\
\text { meaningful evidence } \\
\text { that can be used in } \\
\text { nursing practice or } \\
\text { that is useful to the } \\
\text { nursing discipline? }\end{array}$ & $\begin{array}{l}\text { While the sample } \\
\text { size was small and } \\
\text { the study was } \\
\text { conducted only at } \\
\text { one community } \\
\text { hospital, the study } \\
\text { findings do appear } \\
\text { to be valid. Readers } \\
\text { can have confidence } \\
\text { in the truth value of } \\
\text { the results. The } \\
\text { study does contain } \\
\text { meaningful } \\
\text { evidence that can be } \\
\text { used in nursing } \\
\text { practice. }\end{array}$ \\
\hline
\end{tabular}




\section{Appendix A-6}

Urias, D. S., Varghese, M., Simunich, T., Morrissey, S., \& Dumire, R. (2018).

Preoperative decolonization to reduce infections in urgent lower extremity repairs. European Journal of Trauma and Emergency Surgery, 44, 787-793.

\begin{tabular}{|c|c|c|}
\hline Title & $\begin{array}{l}\text { - Is the title a good } \\
\text { one, succinctly } \\
\text { suggesting key } \\
\text { variables and the } \\
\text { study population? }\end{array}$ & $\begin{array}{l}\text { The title is good, } \\
\text { succinctly suggest } \\
\text { key variables as } \\
\text { well as the study } \\
\text { population. }\end{array}$ \\
\hline Abstract & $\begin{array}{l}\text { Did the abstract } \\
\text { clearly and concisely } \\
\text { summarize the main } \\
\text { features of the report } \\
\text { (problem, methods, } \\
\text { results, } \\
\text { conclusions)? }\end{array}$ & $\begin{array}{l}\text { The abstract very } \\
\text { clearly and } \\
\text { concisely } \\
\text { summarized the } \\
\text { main features of the } \\
\text { report including the } \\
\text { purpose, methods, } \\
\text { results, and } \\
\text { conclusions. }\end{array}$ \\
\hline $\begin{array}{l}\text { Introduction } \\
\text { Statement of the Problem }\end{array}$ & $\begin{array}{l}\text { Was the problem } \\
\text { stated } \\
\text { unambiguously, and } \\
\text { was it easy to } \\
\text { identify? } \\
\text { - Is the problem } \\
\text { statement build a } \\
\text { persuasive argument } \\
\text { for the new study? } \\
\text { Was there a good } \\
\text { match between the } \\
\text { research problem } \\
\text { and the methods } \\
\text { used -that is, was a } \\
\text { quantitative } \\
\text { approach } \\
\text { appropriate? }\end{array}$ & $\begin{array}{l}\text { The problem was } \\
\text { very easy to identify } \\
\text { and was stated } \\
\text { unambiguously as } \\
\text { measuring the } \\
\text { effectiveness in } \\
\text { reducing SSIs in } \\
\text { patients undergoing } \\
\text { repair of lower } \\
\text { extremity fractures. } \\
\text { The problem } \\
\text { statement and the } \\
\text { provided research } \\
\text { data built a } \\
\text { persuasive argument } \\
\text { for the new study. } \\
\text { There was a good } \\
\text { match between the } \\
\text { research problem } \\
\text { and the methods } \\
\text { used, a quantitative } \\
\text { approach was } \\
\text { appropriate for this } \\
\text { study given it was } \\
\text { based on data } \\
\text { collection and } \\
\text { statistics. }\end{array}$ \\
\hline
\end{tabular}




\begin{tabular}{|c|c|c|}
\hline $\begin{array}{l}\text { Hypotheses or Research } \\
\text { Questions }\end{array}$ & $\begin{array}{l}\text { Were research } \\
\text { questions and/or } \\
\text { hypotheses explicitly } \\
\text { stated? If not, was } \\
\text { their absence } \\
\text { justified? } \\
\text { - Were questions and } \\
\text { hypotheses } \\
\text { appropriately } \\
\text { worded, with clear } \\
\text { specification of key } \\
\text { variables and the } \\
\text { study population? } \\
\text { Were the } \\
\text { questions/hypotheses } \\
\text { consistent with } \\
\text { existing knowledge? }\end{array}$ & $\begin{array}{l}\text { The research } \\
\text { question was } \\
\text { explicitly stated. IT } \\
\text { was appropriately } \\
\text { worded with clear } \\
\text { specification of key } \\
\text { variables and the } \\
\text { study population. } \\
\text { The question was } \\
\text { certainly consistent } \\
\text { with existing } \\
\text { knowledge with } \\
\text { references made to } \\
\text { recent research } \\
\text { studies. }\end{array}$ \\
\hline Literature Review & $\begin{array}{l}\text { Was the literature } \\
\text { review up-to-date } \\
\text { and based mainly on } \\
\text { primary sources? } \\
\text { - Did the review } \\
\text { provide a state-of- } \\
\text { the-art synthesis of } \\
\text { evidence on the } \\
\text { problem? } \\
\text { Did the literature } \\
\text { review provide a } \\
\text { strong basis for the } \\
\text { new study? }\end{array}$ & $\begin{array}{l}\text { The literature } \\
\text { review was up-to- } \\
\text { date with most in } \\
\text { the past six years, } \\
\text { some going back } 14 \\
\text { years, and were } \\
\text { based on primary } \\
\text { resources. The } \\
\text { review did provide a } \\
\text { state-of-the-art } \\
\text { synthesis of } \\
\text { evidence on the } \\
\text { problem as well as a } \\
\text { strong basis for the } \\
\text { new study. }\end{array}$ \\
\hline $\begin{array}{l}\text { Conceptual/Theoretical } \\
\text { Framework }\end{array}$ & $\begin{array}{l}\text { Were key concepts } \\
\text { adequately defined } \\
\text { conceptually? } \\
\text { Was a } \\
\text { conceptual/theoretic } \\
\text { al framework } \\
\text { articulated-and, if } \\
\text { so, was it } \\
\text { appropriate? If not, } \\
\text { is the absence of a } \\
\text { framework justified? } \\
\text { Were the } \\
\text { questions/hypotheses } \\
\text { consistent with the }\end{array}$ & $\begin{array}{l}\text { Key concepts were } \\
\text { adequately defined } \\
\text { conceptually in this } \\
\text { study. There was no } \\
\text { conceptual/ } \\
\text { theoretical } \\
\text { framework utilized } \\
\text { in this study. The } \\
\text { absence of a } \\
\text { framework was } \\
\text { justified as this } \\
\text { quantitative study } \\
\text { had a nice flow and } \\
\text { was neatly }\end{array}$ \\
\hline
\end{tabular}




\begin{tabular}{|c|c|c|}
\hline & framework? & $\begin{array}{l}\text { summarized in } \\
\text { various tables. }\end{array}$ \\
\hline $\begin{array}{l}\text { Method } \\
\text { Protection of Human Rights }\end{array}$ & $\begin{array}{l}\text { Were appropriate } \\
\text { procedures used to } \\
\text { safeguard the rights } \\
\text { of study } \\
\text { participants? } \\
\text { Was the study } \\
\text { externally reviewed } \\
\text { by an IRB/ethics } \\
\text { review board? } \\
\text { Was the study } \\
\text { designed to } \\
\text { minimize risks and } \\
\text { maximize benefits to } \\
\text { participants? }\end{array}$ & $\begin{array}{l}\text { Appropriate } \\
\text { procedures were } \\
\text { used to safeguard } \\
\text { the rights of study } \\
\text { participants. There } \\
\text { was no mention of a } \\
\text { review by an IRB } \\
\text { however, there is } \\
\text { mention that since } \\
\text { this was a } \\
\text { retrospective study, } \\
\text { informed consent } \\
\text { was not obtained. } \\
\text { The study was } \\
\text { designed to } \\
\text { minimize risks and } \\
\text { maximize benefits } \\
\text { to participants and } \\
\text { the study made note } \\
\text { that only minimal } \\
\text { personal health } \\
\text { information was } \\
\text { collected and the } \\
\text { data was de- } \\
\text { identified. }\end{array}$ \\
\hline Research Design & $\begin{array}{l}\text { Was the most } \\
\text { rigorous design } \\
\text { used, given the study } \\
\text { purpose? } \\
\text { Were appropriate } \\
\text { comparisons made to } \\
\text { enhance } \\
\text { interpretability of the } \\
\text { findings? } \\
\text { Was the number of } \\
\text { data collection } \\
\text { points appropriate? } \\
\text { Did the design } \\
\text { minimize biases and } \\
\text { threats to the } \\
\text { internal, construct, } \\
\text { and external validity } \\
\text { of the study (e.g., } \\
\text { was blinding used, }\end{array}$ & $\begin{array}{l}\text { The research design } \\
\text { used in this study } \\
\text { was a retrospective } \\
\text { study at a rural } \\
\text { community-based } \\
\text { hospital. The was } \\
\text { the most rigorous } \\
\text { design given the } \\
\text { purpose of the } \\
\text { study. Appropriate } \\
\text { comparisons were } \\
\text { made to enhance } \\
\text { interpretability of } \\
\text { the findings. The } \\
\text { number of data } \\
\text { collection points } \\
\text { was appropriate, but } \\
\text { could have been } \\
\text { expanded to include }\end{array}$ \\
\hline
\end{tabular}




\begin{tabular}{|c|c|c|}
\hline & $\begin{array}{l}\text { was attrition } \\
\text { minimized)? }\end{array}$ & $\begin{array}{l}\text { pre and post- } \\
\text { intervention nasal } \\
\text { swabs for MSSA } \\
\text { and MRSA. There } \\
\text { were not performed } \\
\text { to save money but } \\
\text { would have } \\
\text { provided more } \\
\text { information. The } \\
\text { design did minimize } \\
\text { biases and threats to } \\
\text { the internal } \\
\text { construct and } \\
\text { external validity of } \\
\text { the study. }\end{array}$ \\
\hline Population and Sample & $\begin{array}{l}\text { Was the population } \\
\text { identified? Was the } \\
\text { sample described in } \\
\text { sufficient detail? } \\
\text { Was the best } \\
\text { possible sampling } \\
\text { design used to } \\
\text { enhance the } \\
\text { sample's } \\
\text { representativeness? } \\
\text { Were sampling } \\
\text { biases minimized? } \\
\text { Was the sample size } \\
\text { based on a power } \\
\text { analysis? }\end{array}$ & $\begin{array}{l}\text { The population was } \\
\text { very clearly } \\
\text { identified and the } \\
\text { sample described in } \\
\text { sufficient detail and } \\
\text { was summarized in } \\
\text { provided tables. The } \\
\text { best possible } \\
\text { sampling design } \\
\text { was used to enhance } \\
\text { the sample's } \\
\text { representativeness } \\
\text { and sampling biases } \\
\text { were minimized. } \\
\text { There was no } \\
\text { mention of the } \\
\text { sample size being } \\
\text { based on a power } \\
\text { analysis. }\end{array}$ \\
\hline $\begin{array}{l}\text { Data Collection and } \\
\text { Measurement }\end{array}$ & $\begin{array}{l}\text { Were the operational } \\
\text { and conceptual } \\
\text { definitions } \\
\text { congruent? } \\
\text { Were key variables } \\
\text { measured using an } \\
\text { appropriate method } \\
\text { (e.g., interviews, } \\
\text { observations, and so } \\
\text { on)? } \\
\text { Were specific } \\
\text { instruments }\end{array}$ & $\begin{array}{l}\text { The operational and } \\
\text { conceptual } \\
\text { definitions were } \\
\text { congruent in this } \\
\text { study. The key } \\
\text { variables were } \\
\text { measured } \\
\text { appropriately using } \\
\text { statistical analysis } \\
\text { for the quantitative } \\
\text { study. Specific } \\
\text { instruments were }\end{array}$ \\
\hline
\end{tabular}




\begin{tabular}{|c|c|c|}
\hline & $\begin{array}{l}\text { adequately described } \\
\text { and were they good } \\
\text { choices, given the } \\
\text { study population and } \\
\text { the variables being } \\
\text { studied? } \\
\text { Did the report } \\
\text { provide evidence } \\
\text { that the data } \\
\text { collection methods } \\
\text { yielded data that } \\
\text { were reliable, valid } \\
\text { and responsive? }\end{array}$ & $\begin{array}{l}\text { adequately } \\
\text { described and were } \\
\text { good choices given } \\
\text { this study } \\
\text { population. The } \\
\text { instruments used } \\
\text { were descriptive } \\
\text { demographic } \\
\text { statistics, univariate } \\
\text { analyses, logistic } \\
\text { regression, chi- } \\
\text { squared test, } \\
\text { Fisher's exact test, } \\
\text { and the Mann- } \\
\text { Whitney } U \text { test. } \\
\text { Categorical } \\
\text { variables were } \\
\text { analyzed using } \\
\text { Fisher's exact test. } \\
\text { The report provides } \\
\text { some evidence that } \\
\text { the date collection } \\
\text { methods yielded } \\
\text { data that was } \\
\text { reliable, valid, and } \\
\text { responsive. }\end{array}$ \\
\hline Procedures & $\begin{array}{l}\text { - If there was an } \\
\text { intervention, was it } \\
\text { adequately } \\
\text { described, and was it } \\
\text { rigorously developed } \\
\text { and implemented? } \\
\text { Did most } \\
\text { participants } \\
\text { allocated to the } \\
\text { intervention group } \\
\text { actually receive it? } \\
\text { Was there evidence } \\
\text { of intervention } \\
\text { fidelity? } \\
\text { Were data collected } \\
\text { in a manner that } \\
\text { minimized bias? } \\
\text { Were the staff who } \\
\text { collected data } \\
\text { appropriately }\end{array}$ & $\begin{array}{l}\text { The intervention in } \\
\text { this study was a } \\
\text { decolonization } \\
\text { protocol of bathing } \\
\text { patient with } 2 \% \\
\text { CHG washcloths or } \\
\text { Dynahex 4\% CHG } \\
\text { solution in the pre- } \\
\text { intervention group } \\
\text { and the bathing } \\
\text { protocol as well as a } \\
\text { povidone-iodine } \\
\text { nasal swab } 1 \text { hour } \\
\text { before surgical } \\
\text { incision in the } \\
\text { intervention group. } \\
\text { It was adequately } \\
\text { described, } \\
\text { rigorously } \\
\text { developed and }\end{array}$ \\
\hline
\end{tabular}




\begin{tabular}{|c|c|c|}
\hline & trained? & $\begin{array}{l}\text { implemented. The } \\
\text { participants who } \\
\text { were allocated to } \\
\text { the intervention } \\
\text { group did receive } \\
\text { the intervention. } \\
\text { There was no } \\
\text { evidence of } \\
\text { intervention fidelity. } \\
\text { Data was collected } \\
\text { in a manner that } \\
\text { minimized bias and } \\
\text { the staff was } \\
\text { appropriately } \\
\text { trained on } \\
\text { administered the } \\
\text { intervention } \\
\text { protocol. }\end{array}$ \\
\hline Data Analysis & 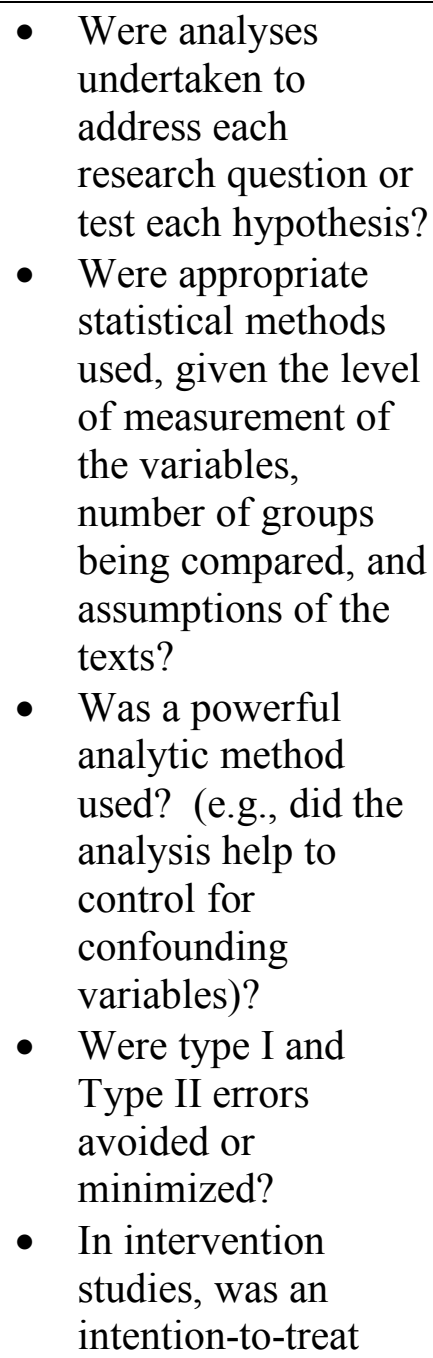 & $\begin{array}{l}\text { There was data } \\
\text { analysis undertaken } \\
\text { to address the } \\
\text { research question. } \\
\text { There was mention } \\
\text { of statistical } \\
\text { methods used and } \\
\text { they were } \\
\text { appropriate to } \\
\text { measure the } \\
\text { variables, number of } \\
\text { groups being } \\
\text { compared, and } \\
\text { assumptions of the } \\
\text { text. There was a } \\
\text { powerful analytic } \\
\text { method used: } \\
\text { logistic regression; } \\
\text { univariate analysis; } \\
\text { chi-squares test; } \\
\text { Fisher's exact test; } \\
\text { and the Mann- } \\
\text { Whitney } U \text { test. } \\
\text { Type I and type II } \\
\text { errors were } \\
\text { minimized. There } \\
\text { was no mention of } \\
\text { an intention-to-treat }\end{array}$ \\
\hline
\end{tabular}




\begin{tabular}{|c|c|c|}
\hline & $\begin{array}{l}\text { analysis performed? } \\
\text { Were problems of } \\
\text { missing values } \\
\text { evaluated and } \\
\text { adequately } \\
\text { addressed? }\end{array}$ & $\begin{array}{l}\text { analysis being } \\
\text { performed. There } \\
\text { were no noted } \\
\text { missing values. }\end{array}$ \\
\hline Findings & $\begin{array}{l}\text { - Was information } \\
\text { about statistical } \\
\text { significance } \\
\text { presented? Was } \\
\text { information about } \\
\text { effect size and } \\
\text { precision of } \\
\text { estimates } \\
\text { (confidence } \\
\text { intervals) presented? } \\
\text { Were the findings } \\
\text { adequately } \\
\text { summarized, with } \\
\text { good use of tables } \\
\text { and figures? } \\
\text { Were findings } \\
\text { reported in a manner } \\
\text { that facilitates a } \\
\text { meta-analysis, and } \\
\text { with sufficient } \\
\text { information needed } \\
\text { for EBP? }\end{array}$ & $\begin{array}{l}\text { Information about } \\
\text { statistical } \\
\text { significance was } \\
\text { presented. } \\
\text { Information about } \\
\text { effect size and } \\
\text { confidence intervals } \\
\text { were presented. The } \\
\text { findings were } \\
\text { adequately } \\
\text { summarized with } \\
\text { good use of tables } \\
\text { and figures. The } \\
\text { findings were } \\
\text { reported in a } \\
\text { manner that } \\
\text { facilitates a meta- } \\
\text { analysis with } \\
\text { sufficient } \\
\text { information needed } \\
\text { for EBP. }\end{array}$ \\
\hline $\begin{array}{l}\text { Discussion } \\
\text { Interpretation of the Findings }\end{array}$ & $\begin{array}{l}\text { Were all major } \\
\text { findings interpreted } \\
\text { and discussed within } \\
\text { the context of prior } \\
\text { research and/or the } \\
\text { study's conceptual } \\
\text { framework? } \\
\text { - Were casual } \\
\text { inferences, if any, } \\
\text { justified? } \\
\text { Was the issue of } \\
\text { clinical significance } \\
\text { discussed? } \\
\text { Were interpretations } \\
\text { well-founded and } \\
\text { consistent with the } \\
\text { study's limitations? } \\
\text { Did the report }\end{array}$ & $\begin{array}{l}\text { All major findings } \\
\text { were interpreted and } \\
\text { discussed within the } \\
\text { context of prior } \\
\text { research. Casual } \\
\text { inferences were } \\
\text { justified. Clinical } \\
\text { significance was } \\
\text { discussed. } \\
\text { Interpretations were } \\
\text { well-founded and } \\
\text { consistent with the } \\
\text { study's limitations. } \\
\text { The report did } \\
\text { address the issue of } \\
\text { generalizability of } \\
\text { the findings noting } \\
\text { that this was at a }\end{array}$ \\
\hline
\end{tabular}




\begin{tabular}{|c|c|c|}
\hline & $\begin{array}{l}\text { address the issue of } \\
\text { the generalizability } \\
\text { of the findings? }\end{array}$ & $\begin{array}{l}\text { small hospital, with } \\
\text { mostly Caucasian } \\
\text { patients, with a } \\
\text { small scope of } \\
\text { surgeries. }\end{array}$ \\
\hline Implications/Recommendations & $\begin{array}{l}\text { Did the researchers } \\
\text { discuss the } \\
\text { implications of the } \\
\text { study for clinical } \\
\text { practice or further } \\
\text { research-and were } \\
\text { those implications } \\
\text { reasonable and } \\
\text { complete? }\end{array}$ & $\begin{array}{l}\text { The researchers did } \\
\text { discuss the } \\
\text { implications of the } \\
\text { study for clinical } \\
\text { practice stating that } \\
\text { the use of intranasal } \\
\text { povidone-iodine is } \\
\text { effective as well as } \\
\text { cost-effective and } \\
\text { further research } \\
\text { should be } \\
\text { performed on } \\
\text { different surgical } \\
\text { procedures. }\end{array}$ \\
\hline $\begin{array}{l}\text { General Issues } \\
\text { Presentation }\end{array}$ & $\begin{array}{l}\text { Was the report well- } \\
\text { written, organized, } \\
\text { and sufficiently } \\
\text { detailed for critical } \\
\text { analysis? } \\
\text { - In intervention } \\
\text { studies, was a } \\
\text { CONSORT } \\
\text { flowchart provided } \\
\text { to show the flow of } \\
\text { participants in the } \\
\text { study? } \\
\text { Was the report } \\
\text { written in a manner } \\
\text { that makes the } \\
\text { findings accessible } \\
\text { to practicing nurses? }\end{array}$ & $\begin{array}{l}\text { The report was well } \\
\text { written, organized, } \\
\text { and sufficiently } \\
\text { detailed for critical } \\
\text { analysis. There was } \\
\text { no CONSORT } \\
\text { flowchart provided } \\
\text { to show the flow of } \\
\text { participants in the } \\
\text { study. The report } \\
\text { was written in a } \\
\text { manner that makes } \\
\text { the findings } \\
\text { accessible to } \\
\text { practicing nurses. }\end{array}$ \\
\hline Researcher Credibility & $\begin{array}{l}\text { Do the researchers' } \\
\text { clinical, substantive, } \\
\text { or methodologic } \\
\text { qualifications and } \\
\text { experience enhance } \\
\text { confidence in the } \\
\text { findings and their } \\
\text { interpretation? }\end{array}$ & $\begin{array}{l}\text { The researchers' } \\
\text { clinical } \\
\text { qualifications and } \\
\text { experience } \\
\text { enhanced } \\
\text { confidence in the } \\
\text { findings and their } \\
\text { interpretation. }\end{array}$ \\
\hline Summary Assessment & $\begin{array}{l}\text { - Despite any } \\
\text { limitations, do the }\end{array}$ & $\begin{array}{l}\text { While this was a } \\
\text { small study at only }\end{array}$ \\
\hline
\end{tabular}




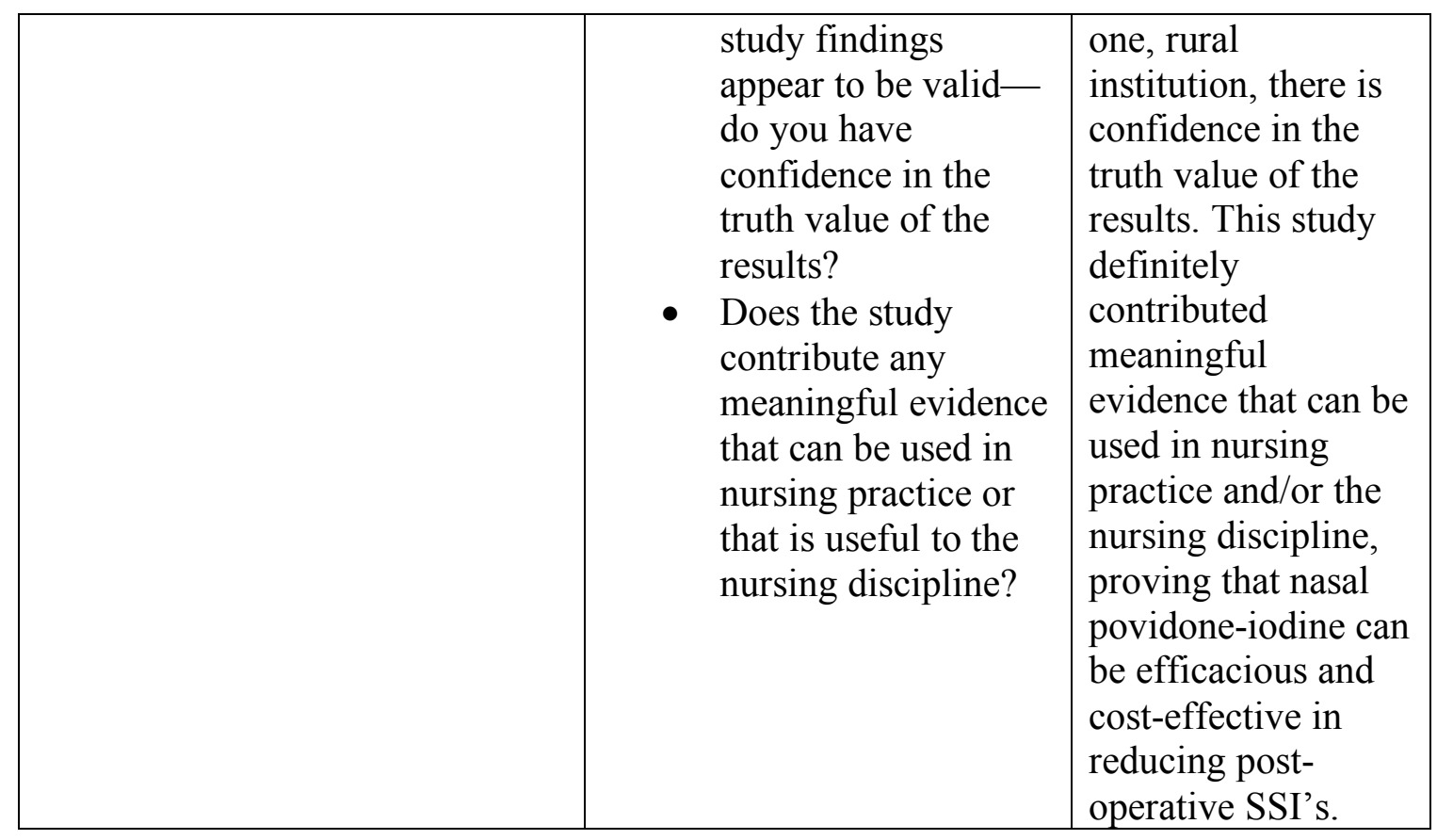




\section{Appendix B-1}

Phillips, M., Rosenberg, A., Shopsin, B., Cuff, G., Skeete, F., Foti, A., Kraemer, K., Inglima, K., Press, B., \& Bosco, J. (2014). Preventing surgical site infections: A randomized, open-label trial of nasal mupirocin ointment and nasal povidone iodine solution. Infection Control Hosp Epidemiol, 35(7), 826-832

\begin{tabular}{|c|c|c|}
\hline Purpose & Methods & Results \\
\hline $\begin{array}{l}\text { To test the hypothesis that } \\
\text { a one-time application of } \\
\text { nasal povidone iodine just } \\
\text { prior to surgery would be } \\
\text { as effective as twice daily } \\
\text { applications of nasal } \\
\text { mupirocin during the five } \\
\text { days before surgery in } \\
\text { preventing SSIs and } \\
\text { provide a more convenient } \\
\text { option for patients at lower } \\
\text { cost. }\end{array}$ & $\begin{array}{l}\text { This was an investigator } \\
\text { initiated, prospective, open- } \\
\text { label, randomized trial. }\end{array}$ & $\begin{array}{l}\text {-Of those subjects in the } \\
\text { intent-to-treat analysis, a } \\
\text { deep SSI caused by S. } \\
\text { Aureus was noted in } 5 \text { of } \\
855 \text { surgeries in the } \\
\text { mupirocin group and } 1 \\
\text { of } 842 \text { surgeries in the } \\
\text { povidone iodine group } \\
\text { (p=0.2). } \\
\text {-A deep SSI caused by } \\
\text { any pathogen developed } \\
\text { in } 14 \text { surgeries in the } \\
\text { mupirocin group and } 6 \\
\text { surgeries in the } \\
\text { povidone iodine group } \\
\text { (p=0.1). } \\
\text {-In the per protocol } \\
\text { analysis, S. aureus deep } \\
\text { SSIs developed in } 5 \text { of } \\
763 \text { surgeries in the } \\
\text { mupirocin group and } 0 \\
\text { of } 776 \text { surgeries in the } \\
\text { povidone iodine group } \\
\text { (p=0.03). } \\
\text {-The findings suggested } \\
\text { that pre-operative nasal } \\
\text { povidone iodine with } \\
\text { topical chlorhexidine is } \\
\text { similar to pre-operative } \\
\text { nasal mupirocin with } \\
\text { topical chlorhexidine in } \\
\text { preventing S. aureus } \\
\text { deep SSI after } \\
\text { arthroplasty and spine } \\
\text { fusion surgery. } \\
\text {-The study also } \\
\text { determined that }\end{array}$ \\
\hline
\end{tabular}




\begin{tabular}{|l|l|}
\hline & $\begin{array}{l}\text { application of nasal } \\
\text { povidone iodine by the } \\
\text { care team just prior to } \\
\text { surgery may ensure } \\
\text { greater compliance. } \\
\text {-The study identified } \\
\text { that S. aureus } \\
\text { colonization pre- } \\
\text { operatively was a } \\
\text { significant risk factor for } \\
\text { subsequent S. aureus } \\
\text { SSI. } \\
\text {-As povidone iodine } \\
\text { costs less than a } \\
\text { mupirocin course, the } \\
\text { authors noted that } \\
\text { povidone iodine } \\
\text { provided more value as } \\
\text { defined as quality of } \\
\text { outcomes divided by } \\
\text { cost. }\end{array}$ \\
\hline
\end{tabular}




\section{Appendix B-2}

Anderson, M. J., David, M. L., Scholz, M., Bull, S. J., Morse, D., Hulse-Stevens, M., \& Peterson, M. L. (2015). Efficacy of skin and nasal povidone-iodine preparation against mupirocin-resistant methicillin-resistant staphylococcus aureus and $\mathrm{S}$. aureus within the anterior nares. Antimicrobial Agents and Chemotherapy, 59(5), 2765-2773.

\begin{tabular}{|c|c|c|}
\hline Purpose & Methods & Results \\
\hline $\begin{array}{l}\text { There were three aims to } \\
\text { this study: to demonstrate } \\
\text { that povidone-iodine nasal } \\
\text { prep is effective at } \\
\text { reducing and preventing } \\
\text { MRSA infection in an ex } \\
\text { vivo model; to show } \\
\text { efficacy against Mup } \\
\text { MRSA in ex vivo human } \\
\text { skin MRSA infection } \\
\text { model and to demonstrate } \\
\text { reduction in the anterior } \\
\text { nares S. aureus bioburden } \\
\text { of human subjects. }\end{array}$ & $\begin{array}{l}\text { This was a quantitative study } \\
\text { with data collected on the } \\
\text { efficacy of povidone-iodine } \\
\text { or mupirocin intranasally in } \\
\text { the treatment of MRSA on } \\
\text { ex vivo porcine vaginal } \\
\text { mucosa, ex vivo human skin, } \\
\text { and the anterior nares of } \\
\text { human subjects. }\end{array}$ & 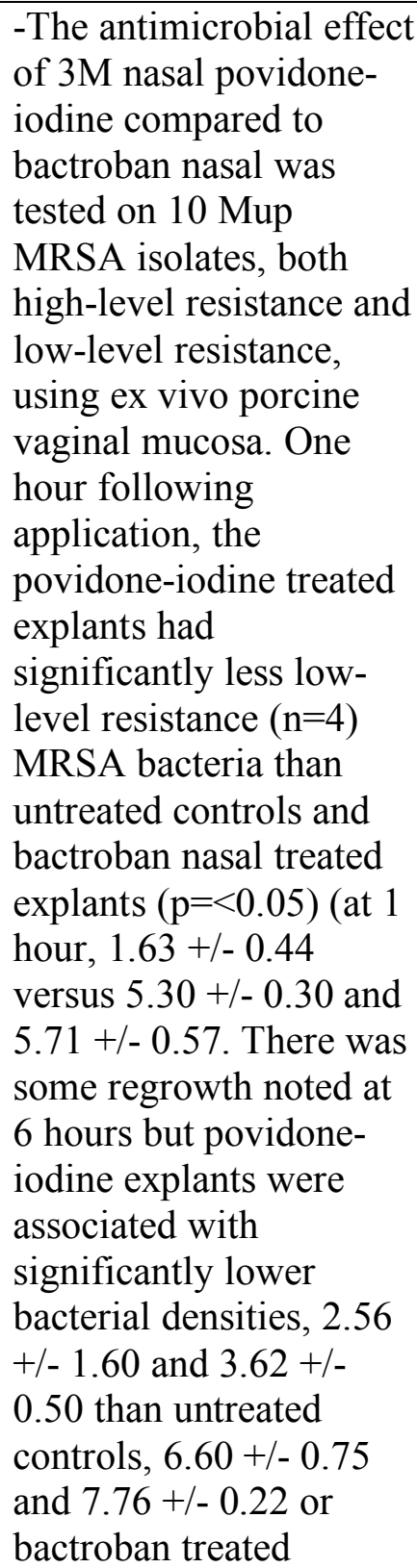 \\
\hline
\end{tabular}




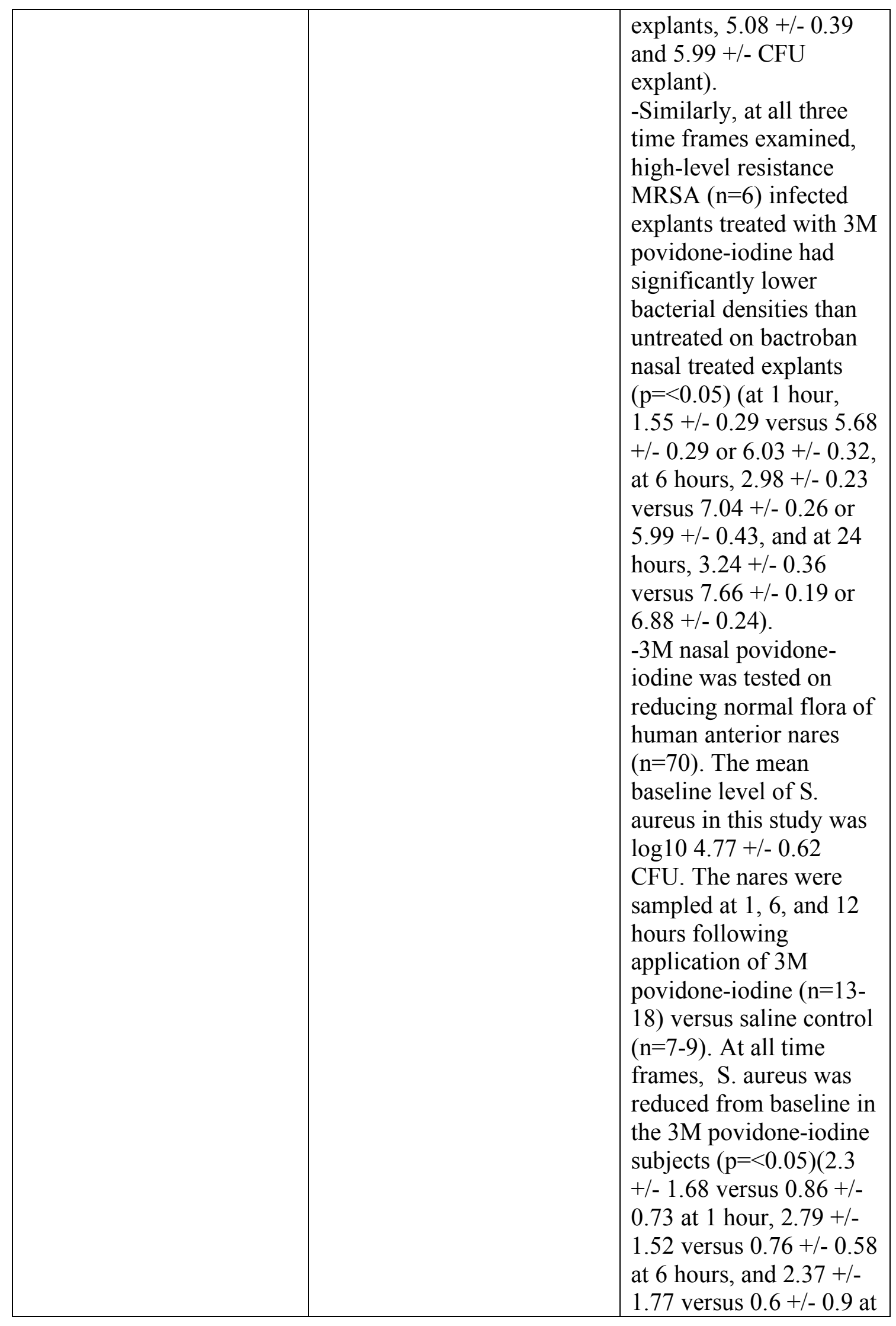




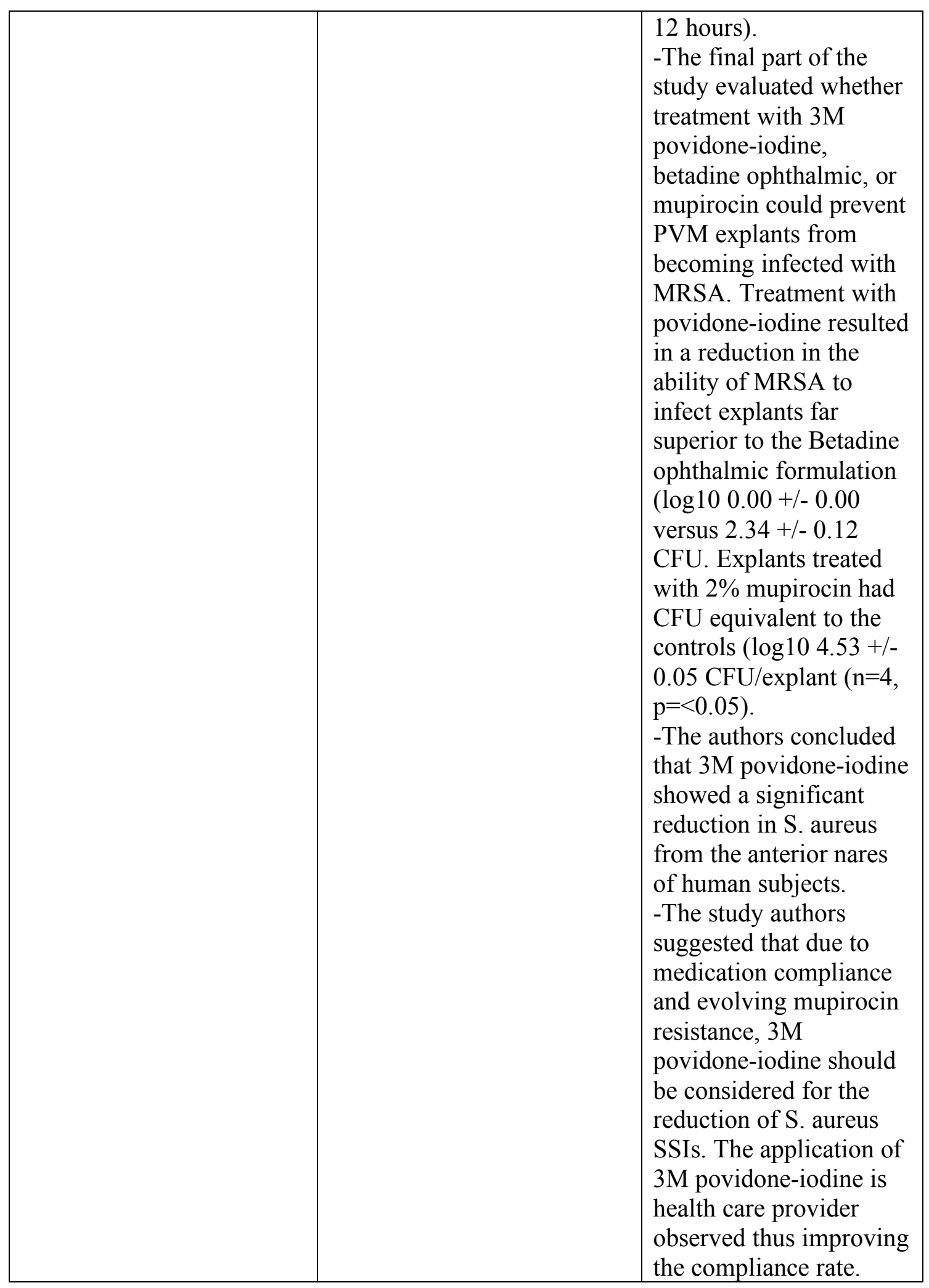




\section{Appendix B-3}

Bebko, S. P., Green, D. M., \& Awad, S. S. (2015). Effect of a preoperative decontamination protocol on surgical site infections in patients undergoing elective orthopedic surgery with hardware implantation. JAMA Surgery, 150(5), 390-395.

\begin{tabular}{|c|c|c|}
\hline Purpose & Methods & Results \\
\hline $\begin{array}{l}\text { The purpose of this study } \\
\text { was to examine the effect } \\
\text { of a decontamination } \\
\text { protocol on SSIs in patients } \\
\text { undergoing elective } \\
\text { orthopedic surgery with } \\
\text { hardware implantation. The } \\
\text { decontamination protocol } \\
\text { consisted of the application } \\
\text { of both chlorhexidine } \\
\text { washcloths and oral rinse } \\
\text { the night before and the } \\
\text { morning of surgery as well } \\
\text { as intranasal povidone- } \\
\text { iodine once the morning of } \\
\text { surgery. }\end{array}$ & $\begin{array}{l}\text { The method for this study } \\
\text { was a prospective clinical } \\
\text { study for patients } \\
\text { undergoing elective } \\
\text { orthopedic surgery with } \\
\text { hardware implants. }\end{array}$ & $\begin{array}{l}\text {-There were } 344 \text { patients } \\
\text { in the control group and } \\
365 \text { patients in the } \\
\text { intervention group. } \\
\text {-There were } 13 \text { patients } \\
\text { in the control group who } \\
\text { developed an SSI } \\
(3.8 \%)(p=.02) \text {. } \\
\text {-There were } 4 \text { patients in } \\
\text { the intervention group } \\
\text { who developed an SSI } \\
\text { (1.1\%)(p=.02). } \\
\text {-A significant reduction } \\
\text { in the number of SSIs } \\
\text { (69.2\%) was noted in } \\
\text { this study in the } \\
\text { intervention group. } \\
\text {-Decontamination was } \\
\text { an independent } \\
\text { protective factor against } \\
\text { the development of an } \\
\text { SSI (CI } 0.08-0.77) \\
\text { (p=.02). } \\
\text {-The results of the study } \\
\text { showed a } 100 \% \\
\text { adherence rate to their } 2- \\
\text { day protocol. } \\
\text {-The authors found that } \\
\text { there was a greater cost } \\
\text { savings using nasal } \\
\text { povidone-iodine and } \\
\text { chlorhexidine } \\
\text { washcloths ( } \$ 35 / \text { patient) } \\
\text { versus } \$ 54.72 \text { per } \\
\text { patient to use mupirocin } \\
\text { and chlorhexidine }\end{array}$ \\
\hline
\end{tabular}


washcloths. 


\section{Appendix B-4}

Sai, N., Laurent, C., Strale, H., Denis, O., \& Byl., B. (2015). Efficacy of the decolonization of methicillin-resistant staphylococcus aureus carriers in clinical practice. Antimicrobial Resistance and Infection Control, 4(56), 1-8.

\begin{tabular}{|c|c|c|}
\hline Purpose & Methods & Results \\
\hline $\begin{array}{l}\text { The purpose of this study } \\
\text { was to evaluate the } \\
\text { effectiveness of two } \\
\text { decolonization protocols } \\
\text { for newly diagnosed } \\
\text { MRSA colonization in } \\
\text { hospitalized patients and to } \\
\text { assess the impact of } \\
\text { decolonization on the rate } \\
\text { of MRSA infection. }\end{array}$ & $\begin{array}{l}\text {-This was a retrospective } \\
\text { cohort study to test two } \\
\text { decolonization protocols on } \\
\text { the rate of MRSA infection } \\
\text { in patients newly diagnosed } \\
\text { as colonized with MRSA. } \\
\text {-Study participants received } \\
\text { one of two decolonization } \\
\text { protocols: the application of } \\
\text { intranasal mupirocin } 2 \% \text { and } \\
\text { washing with chlorhexidine } \\
\text { soap or application of } \\
\text { intranasal povidone-iodine } \\
\text { and washing with povidone- } \\
\text { iodine soap, with each } \\
\text { treatment lasting for } 5 \text { days. }\end{array}$ & $\begin{array}{l}\text { - There were } 268 \\
\text { patients who were } \\
\text { eligible for the } \\
\text { decontamination } \\
\text { protocol in this study. } \\
\text {-39\% of patients were } \\
\text { successfully decolonized } \\
\text { whereas } 164 \text { were not. } \\
\text {-Those treated with } \\
\text { povidone-iodine } \\
\text { intranasally had a } 18 \% \\
\text { success rate in the first } \\
\text { attempt and a } 16 \% \\
\text { success rate in the } \\
\text { second attempt at } \\
\text { decolonization. } \\
\text {-Those treated with } \\
\text { mupirocin intranasally } \\
\text { had a } 51 \% \text { success rate } \\
\text { in the first treatment } \\
\text { attempt and a } 29 \% \\
\text { success rate in the } \\
\text { second attempt. } \\
\text {-The total success rate } \\
\text { for mupirocin was } 56 \% \\
\text { and the total success rate } \\
\text { for povidone-iodine was } \\
23 \% \text {. } \\
\text {-The study showed that } \\
\text { only one-third of } \\
\text { patients were } \\
\text { successfully decolonized } \\
\text { after the first treatment } \\
\text { attempt, with } 39 \% \\
\text { decolonized following } \\
\text { the second attempt, with } \\
\text { no further successes } \\
\text { beyond the first two }\end{array}$ \\
\hline
\end{tabular}




\begin{tabular}{|l|l|}
\hline & $\begin{array}{l}\text { attempts in those with } \\
\text { previous failures. } \\
\text {-Of those who were } \\
\text { successfully decolonized } \\
\text { (n=104), none had a } \\
\text { subsequent MRSA } \\
\text { infection in a median } \\
\text { time frame of 43 days. } \\
\text { Of those unsuccessfully } \\
\text { decolonized (n=164), } \\
\text { had a subsequent MRSA } \\
\text { infection in the median } \\
\text { time frame of 43 days. } \\
\text {-This study had a low } \\
\text { rate of successful } \\
\text { treatment compared to } \\
\text { other studies, which the } \\
\text { authors attributed to } \\
\text { differences in } \\
\text { prevalence of failure risk } \\
\text { factors and a small } \\
\text { sample size. Despite this } \\
\text { low success rate, the } \\
\text { authors concluded that } \\
\text { the effectiveness of } \\
\text { decolonization on the } \\
\text { infection rate justified } \\
\text { the continuation of their } \\
\text { strategy. }\end{array}$ \\
\hline
\end{tabular}




\section{Appendix B-5}

Peng, H. M., Wang, L. C., Zhai, J. L., Weng, X. S., Feng, B., \& Wang, W. (2018). Effectiveness of preoperative decolonization with nasal povidone iodine in Chinese patients undergoing elective orthopedic surgery: A prospective crosssectional study. Brazilian Journal of Medical and Biological Research, 51(2), 1-6.

\begin{tabular}{|c|c|c|}
\hline Purpose & Methods & Results \\
\hline $\begin{array}{l}\text { The purpose of this study } \\
\text { was to assess the } \\
\text { prevalence of } \\
\text { MSSA/MRSA in the } \\
\text { patients admitted to the } \\
\text { study institution and } \\
\text { secondarily to determine } \\
\text { whether the current } \\
\text { treatment protocols result } \\
\text { in the successful } \\
\text { decolonization of } \\
\text { MSSA/MRSA. }\end{array}$ & $\begin{array}{l}\text {-This was a prospective, } \\
\text { cross-sectional study. } \\
\text {-Patients were screened for } \\
\text { nasal MRSA/MSSA } \\
\text { colonization within } 24 \text { hours } \\
\text { of admission. } \\
\text { Those positive for MSSA } \\
\text { and/or MRSA underwent the } \\
\text { decolonization procedure } \\
\text { which was povidone-iodine } \\
\text { swabs in both nostrils twice } \\
\text { a day for five days prior to } \\
\text { surgery as well as } \\
\text { chlorhexidine gluconate } \\
\text { baths for the five days prior } \\
\text { to surgery. }\end{array}$ & $\begin{array}{l}\text {-Out of the } 545 \text { patients } \\
\text { included in this study, } \\
\text { there was a total of } 72 \\
\text { patients who were } \\
\text { positive for MSSA or } \\
\text { MRSA who received the } \\
\text { decolonization } \\
\text { treatment, which } \\
\text { consisted of swabbing } \\
\text { the nares with } 5 \% \\
\text { povidone-iodine nasal } \\
\text { swabs in both nostrils } \\
\text { twice a day for } 5 \text { days } \\
\text { prior to surgery. } \\
\text {-The decolonization was } \\
\text { 100\% successful in } \\
\text { eradicating MRSA } \\
\text { (p=<0.000) and there } \\
\text { was a } 94 \% \text { reduction in } \\
\text { MSSA colonization } \\
\text { (p=<0.001). } \\
\text {-The compliance rate for } \\
\text { the decolonization } \\
\text { protocol was noted to be } \\
98.4 \% \text {. } \\
- \text { The study concluded } \\
\text { that the nasal treatment } \\
\text { with povidone-iodine } \\
\text { was as effective as nasal } \\
\text { mupirocin. }\end{array}$ \\
\hline
\end{tabular}




\section{Appendix B-6}

Urias, D. S., Varghese, M., Simunich, T., Morrissey, S., \& Dumire, R. (2018).

Preoperative decolonization to reduce infections in urgent lower extremity repairs. European Journal of Trauma and Emergency Surgery, 44, 787-793.

\begin{tabular}{|c|c|c|}
\hline Purpose & Methods & Results \\
\hline $\begin{array}{l}\text { The purpose of this study } \\
\text { was to measure the } \\
\text { effectiveness of a CHG } \\
\text { bath preoperatively as well } \\
\text { as nasal painting using } \\
\text { povidone-iodine skin and } \\
\text { nasal antiseptic in reducing } \\
\text { SSIs in patients undergoing } \\
\text { orthopedic operations } \\
\text { conducted at a rural } \\
\text { hospital. }\end{array}$ & $\begin{array}{l}\text {-This was a retrospective } \\
\text { review of trauma patients } \\
\text { undergoing orthopedic } \\
\text { operations at a rural medical } \\
\text { center from 2012-2016 with } \\
\text { the intervention period being } \\
\text { from 2014-2016. } \\
\text {-The CHG baths were } \\
\text { routinely performed from } \\
\text { October } 2012-\text { September } \\
\text { 2016. From October } 2014- \\
\text { September 2016, CHG baths } \\
\text { and nasal povidone-iodine } \\
\text { were routinely performed, } \\
\text { this was the intervention } \\
\text { group. }\end{array}$ & $\begin{array}{l}\text {-This study was } \\
\text { performed from October } \\
1,2012 \text { to September } \\
30,2016 \text { with a total of } \\
1,746 \text { trauma patients } \\
\text { undergoing } 1892 \\
\text { orthopedic surgeries to } \\
\text { repair fractures of the } \\
\text { lower extremities using } \\
\text { hardware. } \\
\text {-There were } 862 \text { patients } \\
\text { in the pre-intervention } \\
\text { group and } 884 \text { patients } \\
\text { in the intervention } \\
\text { group. } \\
\text {-There were a total of } 10 \\
\text { SSI's in the pre- } \\
\text { intervention group } \\
\text { (n=930) and } 2 \text { SSI's in } \\
\text { the intervention group } \\
\text { (n=962) (p=0.020). Of } \\
\text { these SSIs, } 2 \text { were } \\
\text { MRSA in the pre- } \\
\text { intervention and } \\
\text { intervention groups and } \\
8 \text { were MRSA in the } \\
\text { pre-intervention group, } \\
\text { zero being MRSA in the } \\
\text { intervention group. } \\
\text {-There was a significant } \\
\text { decrease in the SSI rate } \\
\text { from } 1.1 \% \text { in the pre- } \\
\text { intervention group to } \\
0.2 \% \text { in the intervention } \\
\text { group (p=0.020). } \\
\text {-The pre-intervention } \\
\text { annual infection rate for }\end{array}$ \\
\hline
\end{tabular}




\begin{tabular}{|l|l|}
\hline & $\begin{array}{l}\text { the first year of the study } \\
\text { was } 1.5 \%(\mathrm{n}=476), \text { the } \\
\text { second year was 0.7\% } \\
(\mathrm{n}=454) \text {. The } \\
\text { intervention annual } \\
\text { infection rate for the } \\
\text { first year of the study } \\
\text { was 0.2\% (n=484) and } \\
0.2 \% \text { for the second year } \\
\text { (n=478). }\end{array}$ \\
$\begin{array}{ll}\text {-The study results } \\
\text { indicated that the results } \\
\text { of this study have } \\
\text { statistical significance, } \\
\text { the protocol is cost } \\
\text { effective, easy to use, } \\
\text { and povidone-iodine is } \\
\text { widely available. The } \\
\text { researchers encourage } \\
\text { multi-center studies and } \\
\text { are employing this } \\
\text { protocol to other } \\
\text { surgical specialties at } \\
\text { their institution. }\end{array}$ \\
\hline
\end{tabular}




\section{Appendix C}

\section{Cross Study Analysis}

\begin{tabular}{|c|c|}
\hline Author & Phillips et al. (2014). \\
\hline Key Findings & $\begin{array}{l}\text {-The use of nasal povidone-iodine pre- } \\
\text { operatively with topical chlorhexidine is } \\
\text { similar in efficacy to using nasal } \\
\text { mupirocin pre-operatively with topical } \\
\text { chlorhexidine in preventing S. aureus } \\
\text { deep SSI after arthroplasty and spine } \\
\text { fusion surgery. } \\
\text {-There was a statistically significant } \\
\text { reduction in S. aureus deep SSI in the per } \\
\text { protocol group, } 5 / 763 \text { cases in the } \\
\text { mupirocin group and } 0 / 776 \text { cases in the } \\
\text { povidone-iodine group (p=0.03). } \\
\text {-Application of nasal povidone-iodine by } \\
\text { the healthcare worker just prior to surgery } \\
\text { may ensure greater compliance. } \\
\text {-Given that this study found povidone- } \\
\text { iodine and mupirocin to be equally } \\
\text { effective, povidone iodine is the more } \\
\text { cost-effective option. }\end{array}$ \\
\hline Recommendations & $\begin{array}{l}\text {-Target enrollment was not met, but } \\
\text { researchers feel study was large enough } \\
\text { that a statistical difference was noted. } \\
\text {-This study was performed at one } \\
\text { institution and could use further studies in } \\
\text { different patient populations. } \\
\text {-Nasal povidone-iodine has proven to be } \\
\text { considered as an alternative to mupirocin } \\
\text { to reduce SSIs. }\end{array}$ \\
\hline Author & Anderson et al. (2015). \\
\hline Key Findings & $\begin{array}{l}\text {-When applied to the anterior nares of } \\
\text { human test subjects, intranasal povidone- } \\
\text { iodine rapidly achieved a significant } \\
\text { reduction of S. aureus }(\mathrm{p}=<0.05) \text {. } \\
\text {-When the efficacy of povidone-iodine } \\
\text { was tested on MRSA-infected ex vivo } \\
\text { human skin, CFU were significantly lower } \\
\text { than the untreated controls. Zero CFU } \\
\text { were recovered from the povidone-iodine } \\
\text { treated explants at } 12 \text { hours post wash. } \\
\text { Intranasal povidone-iodine was }\end{array}$ \\
\hline
\end{tabular}




\begin{tabular}{|l|l|}
\hline & $\begin{array}{l}\text { significantly more effective at reducing } \\
\text { MRSA than Betadine Ophthalmic or } \\
\text { Bactroban Nasal (p=<0.05). }\end{array}$ \\
\hline Recommendations & -The benefits of intranasal povidone- \\
iodine should be considered given issues \\
with medication compliance and evolving \\
mupirocin resistance. \\
-The benefits of intranasal povidone- \\
iodine include: rapid efficacy; broad- \\
spectrum activity against multiple \\
opportunistic pathogens; lack of \\
development of antimicrobial resistance; \\
ease of use; and is directly provided by a \\
health care provider.
\end{tabular}




\begin{tabular}{|c|c|}
\hline Key Findings & $\begin{array}{l}\text {-In this study, } 39 \% \text { of study participants } \\
\text { were successfully decolonized for MRSA, } \\
164 \text { were not. Of those treated with nasal } \\
\text { mupirocin/CHG wash the success rate was } \\
51 \% \text { MRSA reduction in the first attempt } \\
\text { and } 16 \% \text { in the second attempt. Of those } \\
\text { treated with povidone-iodine was and } \\
\text { intranasal povidone-iodine, there was an } \\
18 \% \text { decolonization of MRSA in the first } \\
\text { attempt and } 23 \% \text { in the second attempt. } \\
\text {-The success rates of mupirocin/CHG was } \\
56 \% \text { and the success rate for povidone- } \\
\text { iodine was } 23 \% \text {. } \\
\text {-Of those successfully decolonized } \\
\text { (n=104), there were zero subsequent } \\
\text { MRSA infections. Of the unsuccessfully } \\
\text { decolonized (n=164), there were } 8 \\
\text { subsequent MRSA infections. }\end{array}$ \\
\hline Recommendations & $\begin{array}{l}\text {-Though those participants treated with } \\
\text { povidone-iodine had lower success rates } \\
\text { at eradicating MRSA than those treated } \\
\text { with mupirocin, the povidone-iodine was } \\
\text { applied to the complicated cases, whereas } \\
\text { mupirocin was applied to the } \\
\text { uncomplicated cases. } \\
\text {-The low rate of successful treatment may } \\
\text { be reflected by differences in prevalence } \\
\text { of failure risk factors. } \\
\text {-The researchers suggest that an oral } \\
\text { decolonization component be added to the } \\
\text { decolonization procedures to improve the } \\
\text { result of decolonization. } \\
\text {-While the rate of decolonization was not } \\
\text { high, the effectiveness of decolonization } \\
\text { on the infection rate justifies continuation } \\
\text { of this strategy. }\end{array}$ \\
\hline Author & Peng et al. (2018). \\
\hline Key Findings & $\begin{array}{l}\text {-Pre-decolonization screening showed } 64 \\
\text { patients were positive for MSSA }(\mathrm{n}=72) \\
\text { and } 8 \text { patients were positive for MRSA } \\
(\mathrm{n}=72) \text {. After receiving nasal povidone- } \\
\text { iodine and a daily CHG bath for five days } \\
\text { patients were re-swabbed and } 3 \text { were } \\
\text { positive for MSSA }(0.6 \%) \text { and zero were } \\
\text { positive for MRSA. } \\
\text {-There was a } 94 \% \text { reduction in MSSA }\end{array}$ \\
\hline
\end{tabular}




\begin{tabular}{|c|c|}
\hline & $\begin{array}{l}\text { colonization and a } 100 \% \text { reduction in } \\
\text { MRSA colonization. } \\
\text {-The use of nasal povidone-iodine is more } \\
\text { cost effective than intranasal mupirocin. }\end{array}$ \\
\hline Recommendations & $\begin{array}{l}\text {-This study used a culture swab to test for } \\
\text { MRSA/MSSA rather than by PCR which } \\
\text { could increase the sensitivity of detection. } \\
\text {-The treatment of nasal povidone-iodine } \\
\text { proved to be just as effective as intranasal } \\
\text { mupirocin and is more cost effective. } \\
\text {-The researchers suggest nasal povidone- } \\
\text { iodine be evaluated in larger cohorts of } \\
\text { orthopedic surgery patients to determine } \\
\text { its efficacy in eradicating MRSA/MSSA } \\
\text { colonization to reduce SSIs. }\end{array}$ \\
\hline Author & Urias et al. (2018). \\
\hline Key Findings & $\begin{array}{l}\text {-Of those patients in the pre-intervention } \\
\text { group ( } \mathrm{n}=930) \text {, who were treated with } \\
\text { CHG bath, } 1.1 \% \text { developed an SSI post- } \\
\text { operatively. } \\
\text {-In the intervention group ( } \mathrm{n}=962) \text {, } \\
\text { participants were treated with CHG bath } \\
\text { and intranasal povidone-iodine, } 0.2 \% \\
\text { developed an SSI post-operatively. }\end{array}$ \\
\hline Recommendations & $\begin{array}{l}\text {-The generalizability of the results may be } \\
\text { limited due to the retrospective design, the } \\
\text { focused trauma population, lack of ethnic } \\
\text { diversity, and location. } \\
\text {-The results of this study met statistical } \\
\text { significance, the intervention is cost } \\
\text { effective, easy to use, and the products are } \\
\text { widely available. } \\
\text {-The researchers encourage multi-center } \\
\text { studies to test the effectiveness of the } \\
\text { decolonization protocol in different } \\
\text { patient populations. }\end{array}$ \\
\hline
\end{tabular}

